\title{
Nanotechnology-based antiviral therapeutics
}

\author{
Malobika Chakravarty ${ }^{1} \cdot$ Amisha Vora $^{1}$
}

Published online: 3 August 2020

(C) Controlled Release Society 2020

\begin{abstract}
The host immune system is highly compromised in case of viral infections and relapses are very common. The capacity of the virus to destroy the host cell by liberating its own DNA or RNA and replicating inside the host cell poses challenges in the development of antiviral therapeutics. In recent years, many new technologies have been explored for diagnosis, prevention, and treatment of viral infections. Nanotechnology has emerged as one of the most promising technologies on account of its ability to deal with viral diseases in an effective manner, addressing the limitations of traditional antiviral medicines. It has not only helped us to overcome problems related to solubility and toxicity of drugs, but also imparted unique properties to drugs, which in turn has increased their potency and selectivity toward viral cells against the host cells. The initial part of the paper focuses on some important proteins of influenza, Ebola, HIV, herpes, Zika, dengue, and corona virus and those of the host cells important for their entry and replication into the host cells. This is followed by different types of nanomaterials which have served as delivery vehicles for the antiviral drugs. It includes various lipid-based, polymer-based, lipid-polymer hybrid-based, carbon-based, inorganic metal-based, surface-modified, and stimuli-sensitive nanomaterials and their application in antiviral therapeutics. The authors also highlight newer promising treatment approaches like nanotraps, nanorobots, nanobubbles, nanofibers, nanodiamonds, nanovaccines, and mathematical modeling for the future. The paper has been updated with the recent developments in nanotechnology-based approaches in view of the ongoing pandemic of COVID-19.
\end{abstract}

Keywords Viral infections $\cdot$ Antiviral therapy $\cdot$ Nanotechnology $\cdot$ Nanovaccines

\section{Introduction}

The world has progressed in many realms, but viral diseases continue to exist and contribute to the mortality of humankind along with its varied socioeconomic manifestations. In recent times, there have been outbreaks of several viral infections caused by corona virus, Nipah virus, Ebola virus, Zika virus, dengue virus, chikungunya virus and different strains of influenza virus- $\mathrm{H} 5 \mathrm{~N} 1$ (avian flu) and H1N1 and H3N2 (swine flu). Recently, the novel coronavirus (nCoV) has caused severe pandemic claiming lives of approximately 2.1 lakh people so far, with high impact on socioeconomic implications around the world. In 2018, nineteen Nipah virus cases were reported in India, 17 of which resulted in mortality. Since 2001, the fatality rate due to Nipah virus infection has been

Amisha Vora

amisha.vora@nmims.edu

1 Shobhaben Pratapbhai Patel School of Pharmacy and Technology Management, SVKM's NMIMS, V. L. Mehta Road, Vile Parle (W), Mumbai 400056, India reported to be between 68 and 100\% in India [1]. Major outbreak of Ebola virus disease in West Africa during 2014-2016 claimed 11,315 lives out of 28,616 reported cases. In Australia, in 2019, in the first quarter itself, 27,540 notifications of influenza were received. Although decreased influenza activity is reported for the various continents across the world, different strains of the influenza virus are seen in the various parts of the world with the seasonal influenza $A$ virus predominating [2]. Zika virus transmission has taken over an epidemic proportion in various parts of the world over the past few years. Presently, dengue is seen to afflict South East Asia 17 times more as compared to other viral infections, thus escalating the cost of dengue treatment to about $\$ 950$ million [3]. Further, in May 2018, around 164,000 dengue incidences had struck globally [4]. Therefore, the economic ramifications associated with viral diseases have been quite high. Various risk factors identified for viral infections include environmental risks including water supply, sanitation facility and climate, life style including smoking and alcoholism, particular geographical area, various medical procedures like blood transfusion, surgery, transmission from vectors, etc. While from among these, a few factors are unavoidable and precautions 
need to be exercised to avoid them, efforts can be directed toward the others to elicit positive response [5-7].

The major challenge that remains in the development of effective antiviral agents is the ability of the virus to multiply in the host cell by liberating its own DNA or RNA. The host's immune system is highly compromised in case of viral infections and relapses are very common. Also, due to the complexities associated with viruses, treatment is mostly symptomatic and complete eradication of the virus may not be possible. Distinguishing and diagnosing the exact type of viral disease is quite challenging. At times, due to past exposure, viral antibodies present in the host may get activated, rendering it difficult to detect incidental infections [8]. Difficulties faced in the prevention, detection, or treatment are seen as a red signal by the research community, and newer technologies have been explored to overcome the limitations of present therapies. The present review compiles recent advancements made in this direction and opens up new avenues for further research for diagnosis and treatment of viral infections.

\section{General mechanisms of pathogenesis of viral infections}

Most of the viral infections are subclinical, where the body's defense mechanism arrests the course of infection before the clinical symptoms become apparent. Such infections are of great epidemiological significance as they become the means of spread of the virus through populations. Various stages of pathogenesis of viral disease include the following: (i) attachment of virus at point of entry, (ii) penetration into the host cell, (iii) uncoating of the virus, (iv) replication through transcription and translation leading to the synthesis of virus-specific proteins, (v) assembly of naked capsids through nucleocapsid, and (vi) release of virions resulting in further spread of infections [9]. Factors affecting pathogenesis mechanisms include accessibility of tissue to the causative virus, susceptibility of the cell to viral replication, and the resistance of the virus to the host defense mechanisms. The affinity of the virus to infect specific tissue depends on various factors like the presence of virus-specific receptors on the cell, cell transcription factors which enables the cell to recognize viral promoter and enhancer sequences, local $\mathrm{pH}$, temperature, and presence of enzymes which may inactivate the virus [10]. Mechanisms adopted by the virus to cause destruction of the host cell involve blockade of cellular synthesis of macromolecules compromising cellular energy. Integration of the viral genome with the host genome causing mutations in the host genome is the indirect route to cell damage. The infection process is studied on the basis of virulence, virusdependent factors, virulence genes, amount of inoculum, speed of replication, and degree to which the viral infection spreads [11]. The major issue linked with the study of viral diseases is that it is hard to evaluate the way in which the host defenses would interact with the virus. It may act by preventing the growth of the virus or it may stimulate immunological response in the affected tissue [12]. The basic structures of viruses, certain important proteins of the virus and the host cell which play a significant role in its entry and replication and spread, and currently available FDAapproved treatments and vaccines are presented in Table 1. A pictorial representation of these processes in influenza, dengue, Ebola, Zika virus, herpes infection, and HIV is made in Fig. 1.

\section{Challenges of antiviral treatment}

Continuous efforts in the direction of research on antiviral therapies have improved the quality of life of patients suffering from viral infections. However, the appearance of newer viral infections worldwide and the emergence of multidrug-resistant strains and its transmission have put forward greater challenges to the clinical utility of antiviral therapies.

(i) Some antiviral drugs are known to interact with regular prescription medicines to give adverse drug-drug interactions [30]. Also, the toxic side effects are common outcomes of long-term treatment module, which may further hinder the patients from following their full medicinal regimen.

(ii) Many of the antiviral drugs have short half-life, leading to an increase in the frequency of medication and poor patient compliance [31].

(iii) Development of drug resistance is likely to occur, especially in immunocompromised patients as a result of prolonged drug exposure [32].

(iv) Low bioavailability as a result of limited solubility or permeability may lead to administration of a higher dose and, consequently, may result in toxic effects [33].

(v) Few viruses like HIV, Zika virus, and Ebola spread into inaccessible anatomical regions like the CNS, lymphatic system, and synovial fluid often making it difficult for the drugs to reach resulting in reduced therapeutic efficacy [34].

(vi) Many viral infections remain in the latent stage for a prolonged period and their diagnosis and treatment poses challenges [35].

(vii) Selectivity of antiviral agents toward the virus over the host cell and identification of the target which is unique to virus life cycle is another challenge in their development [36].

(viii) Each virus is unique in its structure and function making the development of a broad-spectrum antiviral agent difficult [37]. 
Table 1 Important viral and host cell proteins and currently FDA-approved drugs and vaccines for different viral infections

\begin{tabular}{|c|c|c|c|c|c|}
\hline $\begin{array}{l}\text { Disease } \\
\text { Causative agent } \\
\text { Family }\end{array}$ & Viral proteins & $\begin{array}{l}\text { Host cell proteins important for } \\
\text { interaction with virus }\end{array}$ & $\begin{array}{l}\text { Currently approved drugs by } \\
\text { FDA }\end{array}$ & $\begin{array}{l}\text { Currently } \\
\text { approved } \\
\text { vaccines }\end{array}$ & Ref \\
\hline $\begin{array}{l}\text { Influenza } \\
\text { Influenza virus A } \\
\text { and B } \\
\text { Negative-sense } \\
\text { single-stranded } \\
\text { RNA virus } \\
\text { (Orthomyxoviridae) }\end{array}$ & $\begin{array}{l}\text { Structural proteins: } \\
\text { Hemagglutinin (HA) } \\
\text { Neuraminidase (NA) } \\
\text { Nucleoprotein (NP) } \\
\text { Matrix proteins: } \\
\text { M1 and M2 } \\
\text { Nonstructural proteins: } \\
\text { NS1 and NS2 } \\
\text { Polymerase subunits PA, } \\
\text { PB1, PB2, and PB1F2 }\end{array}$ & $\begin{array}{l}\text { Sialic acid residues on the } \\
\text { surface, host cell proteases }\end{array}$ & $\begin{array}{l}\text { Oseltamivir, zanamivir, } \\
\text { peramivir, } \\
\text { baloxavir marboxil }\end{array}$ & $\begin{array}{l}\text { A yearly } \\
\text { vaccine } \\
\text { available }\end{array}$ & [13-16] \\
\hline $\begin{array}{l}\text { Ebola } \\
\text { Enveloped, } \\
\text { negative-sense } \\
\text { single-stranded } \\
\text { nonsegmented } \\
\text { RNA virus } \\
\text { Filoviridae } \\
\text { Causing severe } \\
\text { hemorrhagic } \\
\text { fever }\end{array}$ & $\begin{array}{l}\text { Seven structural and two } \\
\quad \text { nonstructural proteins } \\
\text { Structural proteins: } \\
\text { Nucleoprotein (NP) } \\
\text { Capsid proteins: VP30, VP35 } \\
\text { Matrix proteins: VP40 and VP24 } \\
\text { Membrane fusion proteins: } \mathrm{GP}_{1,2} \\
\text { RNA-dependent RNA } \\
\text { polymerase (L) } \\
\text { Nonstructural proteins: } \\
\text { Soluble GP (sGP) and small sol- } \\
\text { uble GP (sSGP) }\end{array}$ & $\begin{array}{l}\text { C-type lectins (CLECs), } \\
\text { phosphatidylserine } \\
\text { (PtdSer receptors), } \\
\text { C domain of NPC1, } \\
\text { two pore calcium channels } \\
\text { Proteases }\end{array}$ & $\begin{array}{l}\text { No currently approved drugs } \\
\text { Drugs under investigation: } \\
\text { Use of monoclonal antibodies } \\
\text { (Zmapp), siRNA } \\
\text { (TKM-Ebola), interferons, } \\
\text { neplanocin derivatives and } \\
\text { endoplasmic reticulum } \\
\alpha \text {-glucosidase inhibitors and } \\
\text { small molecule } \\
\text { nucleoside/nucleotide inhibi- } \\
\text { tors (brincidofovir) }\end{array}$ & $\begin{array}{l}\text { Ervebo } \\
\text { approved } \\
\text { in } \\
\text { December } \\
2019\end{array}$ & {$[17]$} \\
\hline $\begin{array}{l}\text { AIDS } \\
\text { HIV-1 (more } \\
\quad \text { virulent) and } \\
\text { HIV-2 } \\
\text { Single-stranded } \\
\text { positive sense } \\
\text { enveloped virus } \\
\text { Retroviridae }\end{array}$ & $\begin{array}{l}\text { Structural proteins: } \\
\text { Envelope glycoprotein (gp) made } \\
\quad \text { of two subunits: gp120 and } \\
\quad \text { gp41 } \\
\text { Core structural proteins: p18, p24 } \\
\text { Nucleocapsid proteins: p7 } \\
\text { Late assembly proteins: p6 } \\
\text { Regulatory proteins: } \\
\text { Reverse transcriptase (RT) } \\
\text { Integrase } \\
\text { Tat and TAR } \\
\text { Protease }\end{array}$ & $\begin{array}{l}\text { CD4 receptors, chemokine } \\
\text { receptors: CXCR4 or CCR5 } \\
\text { mainly expressed on } \\
\text { macrophages, lymphocytes }\end{array}$ & $\begin{array}{l}24 \text { approved drugs belonging to } \\
\text { the class of nucleoside reverse } \\
\text { transcriptase inhibitors } \\
\text { (NRTIs) and the } \\
\text { non-nucleoside reverse tran- } \\
\text { scriptase inhibitors (NNRTIs), } \\
\text { integrase inhibitors, Tat TAR } \\
\text { interaction inhibitors }\end{array}$ & None & [18-20] \\
\hline $\begin{array}{l}\text { Herpes } \\
\text { Herpes simplex } \\
\text { virus type-1 and } \\
\text { type-2 (HSV-1 } \\
\text { and HSV-2) } \\
\text { Double-stranded } \\
\text { DNA virus } \\
\text { Herpesviridae } \\
\text { (oral and genital } \\
\text { lesions to } \\
\text { encephalitis) }\end{array}$ & $\begin{array}{l}11 \text { glycoproteins including gB } \\
\text { and gC. gD } \\
\text { Tegument proteins, virus-host } \\
\text { shutoff protein (VHS), VP } 16 \\
\text { Regulatory proteins: } \\
\text { Immediate early proteins (IE), } \\
\text { RNA polymerase II } \\
\text { DNA polymerase, helicase } \\
\text { primase }\end{array}$ & $\begin{array}{l}\text { Heparin sulfate proteoglycans } \\
\text { presenting binding sites for } \mathrm{gB} \\
\text { and } \mathrm{gC} \\
\text { Herpes virus entry mediator } \\
\text { (HVEM), nectin } 1 \text { and } 2 \text { and } \\
\text { 3-O sulfated heparin sulfate } \\
\text { (3 OSHS) present the binding } \\
\text { site for gD }\end{array}$ & $\begin{array}{l}\text { Three approved drugs: } \\
\text { Acyclovir } \\
\text { Valacyclovir } \\
\text { Famciclovir } \\
\text { Herpes DNA polymerase } \\
\quad \text { inhibitors } \\
\text { Helicase primase inhibitors }\end{array}$ & None & {$[21,22]$} \\
\hline $\begin{array}{l}\text { Zika virus } \\
\text { positive-stranded } \\
\quad \text { RNA virus } \\
\text { Flaviviridae }\end{array}$ & $\begin{array}{l}\text { Capsid, envelope, precursor of } \\
\text { membrane protein (C, E, and } \\
\text { prM) and the seven } \\
\text { nonstructural proteins (NS1, } \\
\text { NS2A, NS2B, NS3, NS4A, } \\
\text { NS4B, and NS5) }\end{array}$ & $\begin{array}{l}\text { AXL, TIM, TAM, DC-SIGN, } \\
\text { and Tyro } 3 \\
\text { gas } 6\end{array}$ & $\begin{array}{l}\text { None } \\
\text { Like obatoclax, cavinafungin, } \\
\text { sofosbuvir, 7-DMA, } \\
\text { BCX4450, and NITD008 }\end{array}$ & None & [23-25] \\
\hline $\begin{array}{l}\text { Dengue virus } \\
\text { Single-stranded } \\
\text { positive sense } \\
\text { RNA virus }\end{array}$ & $\begin{array}{l}\text { Three structural proteins: } \\
\text { The membrane protein M, } \\
\text { the envelope protein E, } \\
\text { the capsid protein C } \\
\text { Seven nonstructural proteins- } \\
\text { NS1, NS2a, NS2b, NS3, } \\
\text { NS4a, NS4b, NS5 }\end{array}$ & $\begin{array}{l}\text { Glycosaminoglycans (GAGs) } \\
\text { such as heparan sulfate and } \\
\text { lectins, mannose receptors on } \\
\text { macrophages, adhesion mole- } \\
\text { cule of dendritic cells } \\
\text { (DC-SIGN), the lipopolysac- } \\
\text { charide (LPS) receptor CD14, } \\
\text { heat-shock proteins: }\end{array}$ & None & $\begin{array}{l}\text { Dengvaxia } \\
\text { approved } \\
\text { in } \\
\text { May } 2019\end{array}$ & [26-28] \\
\hline
\end{tabular}


Table 1 (continued)

\begin{tabular}{|c|c|c|c|c|c|}
\hline $\begin{array}{l}\text { Disease } \\
\text { Causative agent } \\
\text { Family }\end{array}$ & Viral proteins & $\begin{array}{l}\text { Host cell proteins important for } \\
\text { interaction with virus }\end{array}$ & $\begin{array}{l}\text { Currently approved drugs by } \\
\text { FDA }\end{array}$ & $\begin{array}{l}\text { Currently } \\
\text { approved } \\
\text { vaccines }\end{array}$ & Ref \\
\hline $\begin{array}{l}\text { Corona virus } \\
\text { SARS-CoV2 }\end{array}$ & $\begin{array}{l}\text { Polyproteins PP1a, PP1ab, } \\
\text { proteases } \\
16 \text { nonstructural proteins: } \\
\text { NSP1-NSP16 } \\
\text { Structural proteins: spike protein } \\
\text { (S), nucleocapsid proteins }\end{array}$ & $\begin{array}{l}\text { HSP90/HSP70, ER } \\
\text { chaperonin GRP78 TIM/TAM } \\
\text { Macrophages' Fc } \gamma \text { receptors } \\
\text { Angiotensin-converting enzyme } \\
\text { II receptors (ACEII receptors), } \\
\text { cell surface serine protease } \\
\text { TMPRSS2 }\end{array}$ & None & None & [29] \\
\hline
\end{tabular}

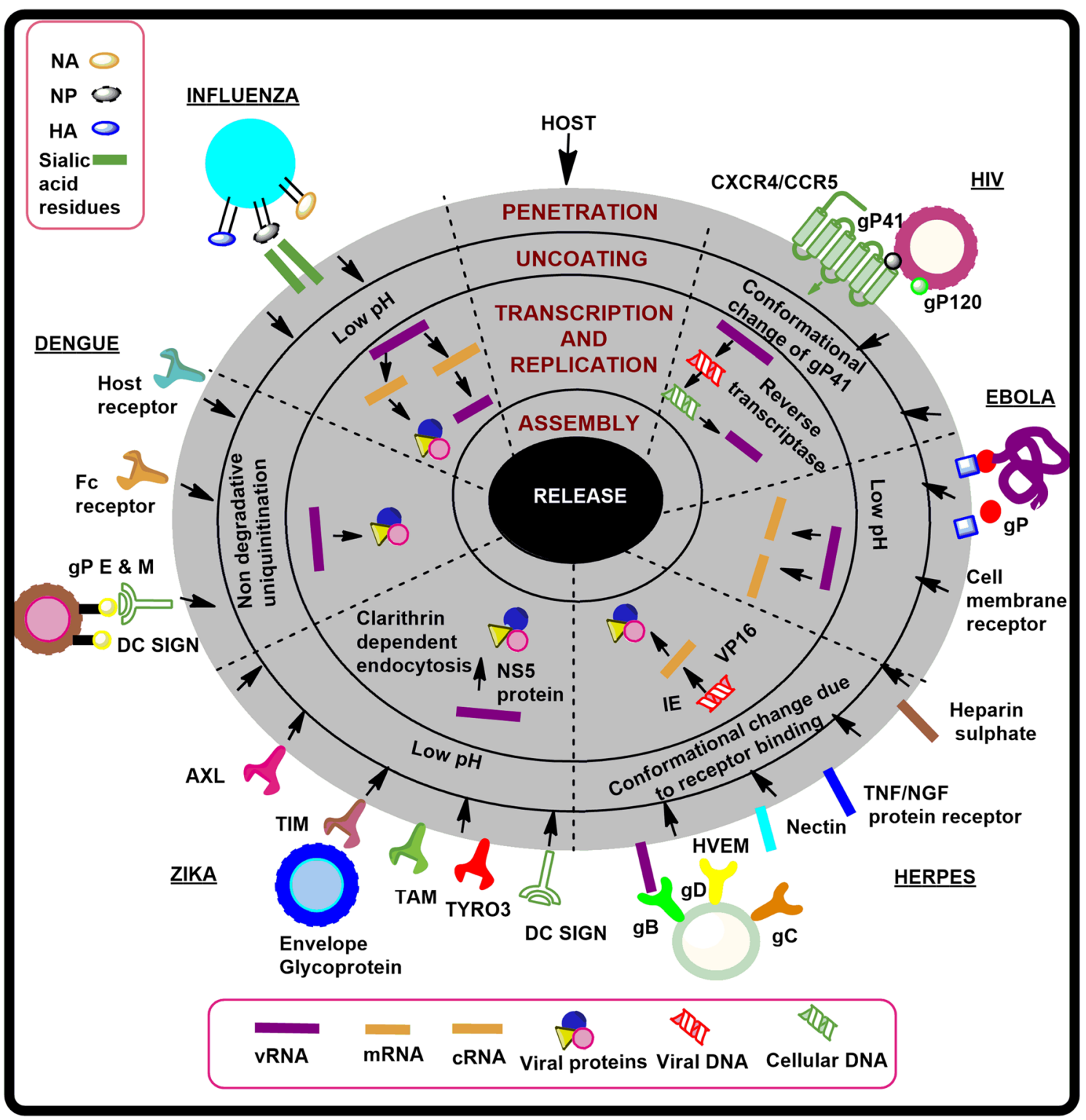

Fig. 1 Pictorial representation of the stages involved in various viral infections 


\section{Application of nanotechnology in antiviral therapeutics}

With the advent of nanotechnology, it has been possible to comprehend the cellular mechanisms of the living cells and to develop relevant technologies which facilitate early diagnosis and treatment of various viral infections [38, 39]. Some of its applications consist of drug and gene delivery; use of fluorescent biological labels, detection of proteins, pathogens, and tumors; separation and purification of biological molecules and cells; tissue engineering; MRI contrast heightening; and pharmacokinetic studies [40-42]. Thus, it has opened up a vast field of research and application with its ability to deal with viral diseases in an efficient manner and address the problems posed by traditional antiviral medicines [43]. Nanoformulations have not only helped to overcome the problems related to drug solubility and bioavailability but also by themselves have acted as antiviral agents through various mechanisms (Fig. 2).

\section{Nanotechnology formulation aspects and their application in disease therapeutics}

\section{Lipid-based nanoformulations}

A variety of lipids have been explored as carriers for antiviral compounds. In contrast to polymers, lipids have advantages of being biodegradable, biocompatible, inert, nontoxic, nonimmunogenic, easily available, and cheaper [44].
Moreover, lipids possess unique characteristics like smaller size, larger surface area, high drug-loading capacity, improved interface interactions, controlled release, and enhanced overall performance of the drug they deliver [45]. They augment bioavailability, improve pharmacokinetic profile, reduce toxicity, and achieve the desired concentration of the drug at otherwise inaccessible sites through various mechanisms [46]. Some of the commonly used lipids are lecithins, triglycerides (trimyristin, tripalmetin), glyceryl palmitostearate, and fatty acid (beeswax, carnauba wax). They are generally used along with surfactants (up to 30\%) and co-solvents (up to 10\%) in order to maximize drug solubility [47]. Lipid-based nanoformulations include liposomes, solid lipid nanoparticles (SLN), nanoemulsions, and nanosuspensions.

\section{Liposomes}

Liposomes employ small spherical vesicles, $15-1000 \mathrm{~nm}$ in size, generated by the use of phospholipids that entrap an aqueous core into which the drug is dispersed. Various targeting ligands may be attached to their surface for site specificity. Liposomes have the capacity to trap and deliver both hydrophilic and hydrophobic drugs. The lipid layers of liposomes protect the drug from gastrointestinal degradation and help in its sustained release [48]. In spite of its proved effectiveness as a nanodelivery system, its use is restricted due to low drug-loading capacities and physical instability-related issues encountered during its storage and administration [49]. Frequently used preparation techniques of liposomes include passive and active loading technique, detergent
Fig. 2 Limitations of conventonal antiviral drugs and advantages of nanoformulations

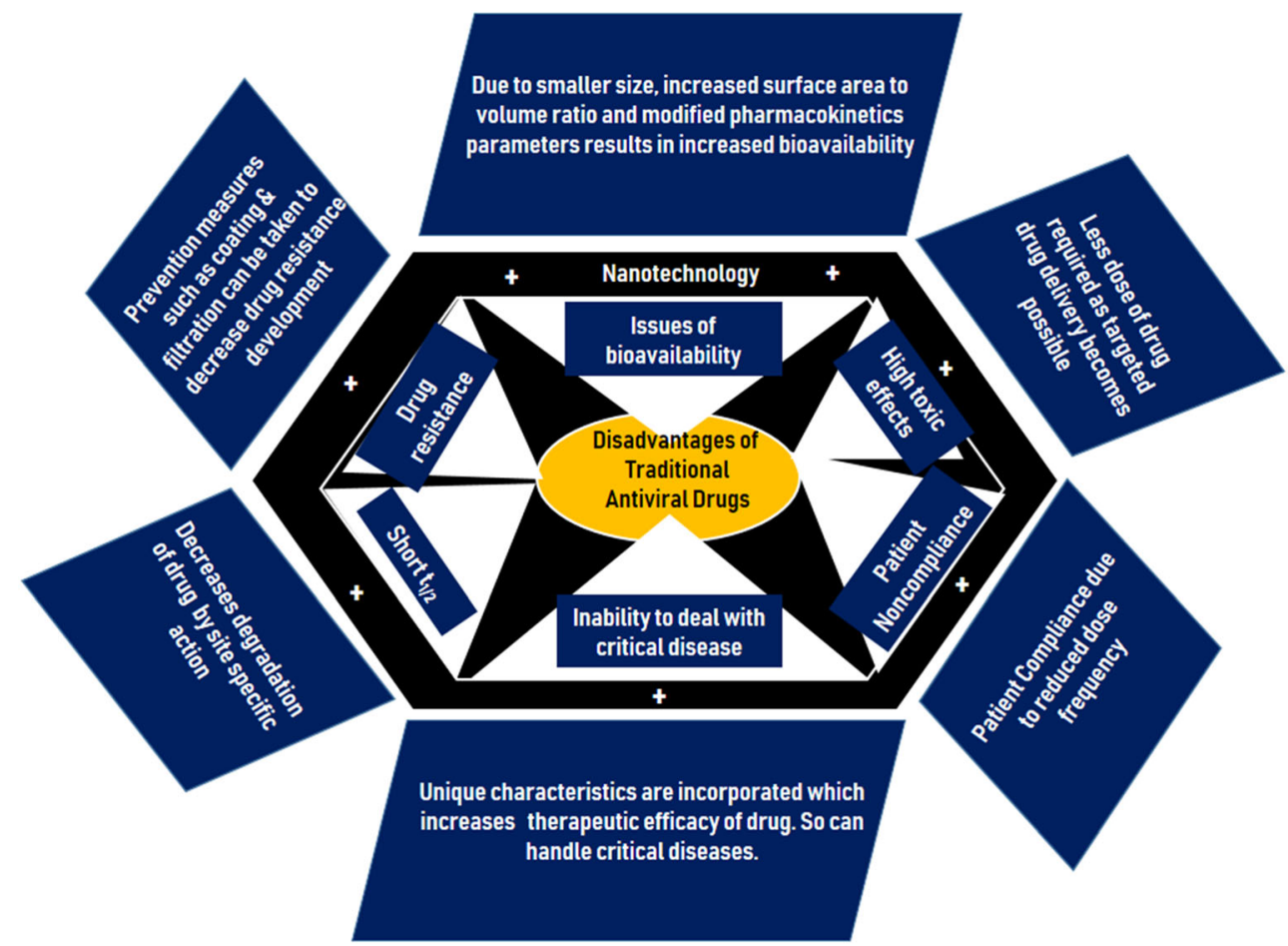


removal method, solvent dispersion method, mechanical dispersion method using sonication, supercritical fluid technology, dual asymmetric centrifugation, membrane contactor technology, cross-flow filtration technology, and freeze-drying technology [50].

\section{Solid lipid nanoparticles}

Solid lipid nanoparticles (SLNs) are colloidal systems composed of a solid lipid matrix and have their diameters in the range of $10-1000 \mathrm{~nm}$. This category of solid lipids includes triglycerides, partial glycerides, steroids, fatty acids, and waxes. SLNs differ from liposomes in the aggregation status of lipids. They are designed to achieve controlled drug release profile, improved stability, increased loading capacity, and targeted drug delivery as a result of being able to be functionalized [51]. The preparation techniques adopted are solvent emulsification/evaporation, emulsification-diffusion, high pressure homogenization, ultrasonication, supercritical assisted injection in a liquid antisolvent (SAILA), fluid extraction of emulsions, and spray-drying [45]. SLNs are proved to be industrially scalable. SLNs have been used for delivery of various antiviral drugs like ritonavir, maraviroc, darunavir, efavirenz, zidovudine, and lopinavir using various lipids like Gelucire 44/14 and Compritol 888ATO. These formulations have been found to have advantages of improved permeability, bioavailability, retardation of P-gp efflux or cytochrome P 450 metabolism, increased uptake by lymphatic system, decreased first-pass metabolism, prolonged release, and better tissue distribution [52]. In another study, dolutegravir (DTG) was myristoylated and its nanoformulation was studied for in vitro release profile. From the results, nanoformulation of myristoylated DTG emerged as a long-acting formulation against HIV infection with slow-release potential [53].

Nanostructured lipid carriers (NLCs) are considered as second-generation SLNs and make use of liquid lipids which present better loading capacity accompanied by better stability and controlled release pattern in comparison with SLNs [54]. Additionally, they also can be surface modified to achieve target specificity. NLCs formulated for the delivery of nevirapine using stearic acid, oleic acid, and Compritrol 888 ATO have shown superior release kinetics as compared to pure drug and its SLNs [55] and NLCs of saquinavir formulated with the use of Precirol ATO5 and Miglyol 812 N/F have shown increased transport across Caco-2 cell monolayers as compared to pure drug [56].

\section{Nanoemulsions}

Nanoemulsions (NE) are single-phase thermodynamically stable systems consisting of oil, water, and surfactants and cosurfactants with globule size in the range of $20-500 \mathrm{~nm}$. Various methods like low-energy emulsification method, phase inversion temperature method ultrasonication, high pressure homogenization, or microfluidization are used for their preparation [57]. Various oils like soyabean oil, castor oil, and peanut oil have been used as lipids [58]. NEs have advantages of increasing aqueous solubility, loading capacity, increased residence time in GIT, enhanced absorption and bioavailability, and lymphatic uptake [59]. Manyarara et al. developed nevirapine nanoemulsion using a blend of soyabean oil, ethyl oleate, and oleic acid as lipid phase. The formulation showed low drug efflux and better release profile and permeability than the drug itself [60]. In another study, saquinavir nanoemulsion was using various edible oils, Lipoid 80 , and deoxycholic acid to improve the drug's brain targeting potential [61]. Prabhakar et al. developed indinavir nanoemulsion using Tween $80(1 \%)$ as co-emulsifier to improve its brain delivery and proposed enhanced LDLmediated endocytosis and Tween 80-mediated P-gp inhibition as mechanism for effective uptake of indinavir by the brain [62].

\section{Self-nanoemulsifying drug delivery systems}

Self-nanoemulsifying drug delivery systems (SNEDDS) are another type of lipid-based monotropic systems which are formed by spontaneous emulsification of oil or lipid with water with the help of surfactant, co-surfactant, solvents, and cosolvents and gentle stirring. The hydrophobic drug is solubilized in the oil phase. They are thermostable and nanosized oil droplets and ensure better penetration and bioavailability [63]. Various antiretroviral drugs have been formulated using various lipids like Capryol 90, Lauroglycol 90, Labafril, and Capmul MCM. Nevirapine formulated as SNEDDS using Captex 200 as lipid, Tween 20 as surfactant, and Capmul MCM as co-surfactant was found to possess $98.9 \%$ release in the aqueous media of GIT as compared to $14.74 \%$ in case of drug solution [64].

\section{Lipid nanoparticles for siRNA delivery}

Recently, gene silencing by RNA interference (RNAi) strategy has been exploited for antiviral treatment. Small interfering RNA (siRNA) is the most commonly used RNAi tool which can target particular genes to cause their short-term silencing and thus blocking the production of respective proteins. They are short (19-21 nucleotides), double-stranded designed and synthesized to target a particular mRNA. They are transfected into the cells with the help of cationic lipid (as liposomes or lipid nanoparticles) or polymers [65]. The structural features which make lipids efficient vehicles for the delivery of siRNA are their polyunsaturated chains significant in the destabilization of intracellular membranes and the ionizable tertiary amino group which helps in the initial fusion of lipid nanoparticles (LNPs) with the cell membrane. Along with cationic lipids, 
helper lipids like fusogenic phospholipids or polyethylene glycols are also added in the formulation. They help to enhance the transfection efficiency and reduce the immunogenic response by protecting them from the macrophages. In addition, cholesterol is added in such formulations to enhance the stability of LNPs and enhance the activity of cationic lipids [66].

Arbutus Biopharma Corporation used (2015) formulated siRNA encapsulated in LNPs in the form of IV injections to target EBOV (TKM-Ebola), and it was found to be effective in the early stages of infection in macaques; however, the phase of clinical trials was withheld due to immune response observed in some patients during dose escalation [67].

Leung and others mentioned about formulating siRNA LNPs for the treatment of Ebola. siRNA acts by blocking the production of any protein responsible for any disease and using LNP as nanocarrier can further lead to improved performance. So for Ebola, LNP siRNA technology consisting of three diverse siRNA sequences targeting the $\mathrm{L}$ polymerase, viral protein 24 , and viral protein 35 of Zaire Ebola virus (ZEBOV) was utilized [68]. Results showed the potential of RNA interference as an effective postexposure therapy strategy for individuals infected with Ebola virus, and further suggestion was made that this strategy could be extended to other types of viruses. Table 2 presents a compilation of various lipid-based nanodelivery systems for antiviral therapeutics.

\section{Polymer-based nanoformulations}

Different types of polymers are used in the preparation of nanoformulations like natural hydrophilic and synthetic hydrophobic polymers. Natural hydrophilic polymers include proteins like gelatin, albumin, lectin, and polysaccharides like alginate, dextran, chitosan, and agarose. Synthetic hydrophobic polymers include the use of polylactic acid (PLA), polylactide-co-glycolic acid (PLGA), polystyrene, poly( caprolactone) (PECL), and polymerized in process poly(isobutylcyanoacrylate) (PICA), polybutylcyanoacrylate, polyhexylcyanoacrylate, and polymethacrylate (PMMA) [76]. Several surface-modified polymers have been used to reduce the nonspecific interaction with serum proteins and uptake by phagocytosis so as to bring about favorable alterations in pharmacokinetic parameters of the drug (as shown in Table 3). Also, various polymeric nanocarriers have been designed in a manner that the drug release can be stimulated by variations in environmental $\mathrm{pH}$, chemical stimuli, and use of a quickly oscillating magnetic field or an external heat source. This has helped in the prevention of drug degradation before it reaches the site of action and the subsequent increase in bioavailability and reduced toxic effects at nonspecific sites [97]. Certain polymers (e.g., Solutol HS15) have an inherent property of inhibiting efflux proteins like P-gp [98]. This may result in enhanced penetration of the drug into the cells that are otherwise inaccessible. Though polymers can serve various functions, their use remains limited due to high cost and safety and compatibility issues [47]. Researchers are working to solve these issues and are trying to provide polymers that are biodegradable and safe to use.

There are certain factors that need to be taken into consideration before selection of a polymer, which includes: (i) preferred size of nanoparticles; (ii) physicochemical properties of the drug that needs to be entrapped in the polymer; (iii) desired surface properties and functions; (iv) release of drug from polymer; (v) extent of biocompatibility, safety, and biodegradability; and (vi) effectiveness and antigenicity of the ultimate product [99]. Polymer-based nanoformulation includes polymeric micelles, polymeric solid nanoparticles, nanocapsules, and nanospheres.

\section{Polymeric micelles}

Polymeric micelles are nanosized structures (typically 10 $100 \mathrm{~nm}$ ) made of amphiphilic block copolymers, each unimer consisting of two segments of distinct chemical nature, one being comparatively hydrophobic and the other hydrophilic. Beyond critical micellization concentration (CMC), the unimers associate to form the supramolecular nanosized structures called micelles with a hydrophobic core and a hydrophilic shell [100-102]. The hydrophobic core helps in the incorporation of poorly water-soluble drug and the hydrophilic shell polymer acts as a barrier to protect the drug cargo and minimizes the nonspecific interactions with enzymes, proteins, and cells. It helps in avoiding its clearance by the reticular endothelial system (RES), thus increasing the circulation time that results in increased accumulation and enhanced therapeutic efficacy [103, 104]. Chemical encapsulation of the drug can be achieved by conjugating the drug chemically with the hydrophobic part of the block copolymer, allowing higher drug loading and minimal premature release [105]. Complexing the micellar surface with specific ligands or monoclonal antibodies has provided advantages of targeted drug delivery using polymeric micelles [106]. Among the most widely explored core-forming polymers are polyesters, polycaprolactone, poly(L-amino acids), and poloxamers. Polyethylene glycol (PEG) is the most widely used shellforming block of the surfactant. Poly-(N-isopropylacrylamide) and poly(methacrylic acid) have been explored for designing shells sensitive to $\mathrm{pH}$ and temperature. Various techniques like solvent extraction, dialysis method, and solution casting method are used for formulating polymeric micelles [107]. Polymeric micelles have been tried for delivering acyclovir. Sawdon and Peng used acyclovir directly to initiate the polymerization of $\varepsilon$-caprolactone to form the hydrophobic core of acyclovir-polycaprolactone. This was further grafted with methoxy polyethylene glycol to form the amphiphilic 
Table 2 Lipid-based nanoformulation

\begin{tabular}{|c|c|c|c|c|c|}
\hline Diseases & $\begin{array}{l}\text { Antiviral } \\
\text { drug }\end{array}$ & $\begin{array}{l}\text { Type of nanodelivery } \\
\text { system }\end{array}$ & Lipid/polymer used as carrier & Key findings & Ref \\
\hline HIV & Stavudine & Gelatin liposomes & Soya lecithin, gelatin & $\begin{array}{l}\text { Improves targeting to a } \\
\text { reservoir site }\end{array}$ & [69] \\
\hline $\begin{array}{l}\text { VZV, diseases caused by herpes } \\
\text { zoster, herpes simplex virus }\end{array}$ & Acyclovir & $\begin{array}{l}\text { Solid lipid } \\
\text { nanoparticles }\end{array}$ & Compritol 888 ATO and soya lecithin & $\begin{array}{l}\text { Controls residual viremia } \\
\text { Improve transdermal delivery }\end{array}$ & {$[70]$} \\
\hline $\begin{array}{l}\text { Conjunctival, corneal, and } \\
\text { intraocular infections and } \\
\text { retinitis }\end{array}$ & Acyclovir & $\begin{array}{l}\text { Solid lipid } \\
\text { nanoparticles }\end{array}$ & Stearic acid, Cithrol GMS, Compritol & Improve ocular delivery & [71] \\
\hline HIV & Efavirenz & $\begin{array}{l}\text { Solid lipid } \\
\text { nanoparticles }\end{array}$ & Glyceryl monostearate, Tween 80 & Enhances solubility & {$[72]$} \\
\hline HIV & Lopinavir & SLN & Stearic acid & $\begin{array}{l}\text { High LPV accumulation in } \\
\text { lymphoidal organs }\end{array}$ & [73] \\
\hline HIV, herpes infection & Acyclovir & $\begin{array}{l}\text { Nanostructured lipid } \\
\text { carrier }\end{array}$ & $\begin{array}{c}\text { Compritol } ® 888 \text { ATO, Lauroglycol }{ }^{\mathrm{TM}} \\
90 \text { Capryol }^{\mathrm{TM}} 90, \text { Tween }^{\circledR} 40\end{array}$ & Increased permeation & {$[74]$} \\
\hline HIV & Indinavir & Lipid nanoemulsion & Cholesterol, Tween 80 & Improved drug permeability & [62] \\
\hline HIV & Saquinavir & Nanoemulsion & Lipoid®-80 & $\begin{array}{l}\text { Improved bioavailability } \\
\text { Higher amount of the drug } \\
\text { was able to reach the brain }\end{array}$ & [61] \\
\hline Herpes infection & $\begin{array}{l}\text { Acyclovir } \\
\text { palmitate }\end{array}$ & $\begin{array}{l}\text { Reconstituted HDL } \\
\text { acyclovir palmitate }\end{array}$ & $\begin{array}{l}\text { Phosphatidylcholin, sodium } \\
\text { deoxycholate }\end{array}$ & High liver targeting property & {$[75]$} \\
\hline
\end{tabular}

block copolymer which could self-assemble to form the nanosized polymeric micelles in the aqueous medium [78]. These polymeric micelles were found to enhance drugloading capacities and eliminate drug-loading steps. In another study, a multifunctional poly(L-lactic acid)-b-poly(ethylene glycol) (PLLA-b-PEG) copolymer modified with a sialic acid derivative (methyl-b-neuraminic acid, mNA) was prepared and further used to form polymeric micelles. Amantidine was loaded in these micelles and sialic acid is known to bind hemagglutinin of influenza viruses to inhibit the virusmediated hemagglutination and infection [108].

\section{Polymeric nanoparticles}

Polymeric nanoparticles are the basic nanocarriers fabricated using a variety of natural or synthetic polymers using a number of preparation techniques like solvent evaporation, emulsion-diffusion evaporation, nanoprecipitation, salting out, dialysis, supercritical fluid technology, polymer dispersion, coacervation, ionic gelation, spray-drying, phase inversion temperature methods, and interfacial polymerizationcontrolled/living radical polymerization [109]. Polymeric nanoparticles which incorporate the drug molecule into its core are termed as nanocapsules $(<300 \mathrm{~nm}$ in size), whereas polymeric nanoparticles in which the drug is adsorbed onto its surface or embedded in the matrix are known as nanospheres $(10-200 \mathrm{~nm}$ in size) $[110,111]$. The advantages of polymeric nanoparticles as carrier system include controlled release, better cellular uptake, protection of drug molecule from degradation site-specific delivery, low toxicity, and their ability to be used as theranostics $[112,113]$. Polymeric nanoparticles have been widely explored for enhancing the efficacy of antiretroviral drugs due to their high applicability in targeting monocytes and macrophages in the brain and lymphatic system which are the principal reservoirs for viral dissemination during HIV infections [114]. Various surface modifications and ligand conjugation approaches have been found to exhibit added advantages of promoting receptor-mediated endocytosis and hence increased uptake by the target cells. Polyethylene oxide, polyethylene glycol, poloxamers, mannose, thiamine, and Tat are among the various surface modifiers tried for targeted HIV therapy [115].

\section{Polymer drug conjugates}

Polymer drug conjugates are comprised of a polymer and a therapeutic agent covalently bound, the therapeutic agent being a small molecule or a large molecule like protein [116]. The purpose of conjugation is to achieve better efficacy through extended plasma stability and safety through targeted delivery $[117,118]$. Besides cancer, such conjugates have found tremendous potential in antiviral therapy. Some polymers are known to possess their inherent antiviral activity and their conjugation with antiviral drugs may act in a synergistic manner. Conjugation of interferon $\alpha 2 \mathrm{~A}$ and $\alpha 2 \mathrm{~A}$ with polyethylene glycol (PEG) has been found effective against HCV [119]. Polymers containing sialic acid functionality were designed and found to be potent inhibitors of viral entry through competitive multivalent binding to hyaluronic acid (HA) and NA on the viral envelope [120]. Various negatively charged polymers like poly(methacrylic acid) (PMAA) and different glycosaminoglycans such as heparin, heparan sulfate, 
Table 3 Polymer-based nanoformulation

\begin{tabular}{|c|c|c|c|c|c|}
\hline Diseases & Antiviral drug & $\begin{array}{l}\text { Type of nanodelivery } \\
\text { system }\end{array}$ & Lipid/polymer used as carrier & Key findings & Ref \\
\hline HIV & $\begin{array}{l}\text { Efavirenz, } \\
\text { darunavir, } \\
\text { indinavir }\end{array}$ & Polymeric micelles & $\begin{array}{l}\text { Poly(ethylene oxide)-poly(propylene oxide) block } \\
\text { copolymer }\end{array}$ & $\begin{array}{l}\text { Protects against } \\
\text { degradation } \\
\text { Enhances solubility } \\
\text { Improves palatability for } \\
\text { pediatric formulations }\end{array}$ & {$[77]$} \\
\hline HSV & Acyclovir & Polymeric micelles & $\begin{array}{l}\text { Acyclovir-polycaprolactone (core)-methoxy PEG } \\
\text { (shell) copolymer }\end{array}$ & $\begin{array}{l}\text { Nontoxic } \\
\text { Efficient drug delivery }\end{array}$ & {$[78]$} \\
\hline Hepatitis B & $\begin{array}{l}\text { Lamivudine } \\
\text { stearate } \\
\text { (prodrug) }\end{array}$ & Polymeric micelles & $\begin{array}{l}\text { Stearic acid-grafted chitosan oligosaccharide poly- } \\
\text { meric micelles }\end{array}$ & $\begin{array}{l}\text { High drug loading, high } \\
\text { cellular uptake in } \\
\text { HBV-transfected human } \\
\text { hepatoblastoma cells, } \\
\text { more conspicuous inhi- } \\
\text { bition of antigen expres- } \\
\text { sion and DNA replica- } \\
\text { tion }\end{array}$ & [79] \\
\hline HIV & Nevirapine & Polymeric nanoparticles & Cellulose acetate butyrate & $\begin{array}{l}\text { Increased therapeutic } \\
\text { efficacy } \\
\text { Decreased } \\
\text { biocompatibility }\end{array}$ & {$[80]$} \\
\hline HIV & $\begin{array}{l}\text { Efavirenz } \\
\quad \text { (transferrin } \\
\text { receptor-binding } \\
\text { peptide) }\end{array}$ & Polymeric nanoparticles & PLGA & $\begin{array}{l}\text { Increased stability to } \\
\text { interact with BBB } \\
\text { Increased permeability }\end{array}$ & {$[81]$} \\
\hline HIV & Nevirapine & Polymeric nanoparticles & PLGA nanoparticles conjugated with transferrin & $\begin{array}{l}\text { Increased uptake in human } \\
\text { brain microvascular } \\
\text { endothelial cells }\end{array}$ & {$[82]$} \\
\hline HIV & Zidovudine & Polymeric nanoparticles & $\begin{array}{l}\text { CRM 197-grafted zidovudine-loaded } \\
\text { polybutylcyanoacrylate nanoparticles }\end{array}$ & $\begin{array}{l}\text { Increased uptake in human } \\
\text { brain microvascular } \\
\text { endothelial cells }\end{array}$ & {$[83]$} \\
\hline HIV & Lamivudine & Polymeric nanoparticles & $\begin{array}{l}\text { Chitosan cross-linked with glutaraldehyde nanoparti- } \\
\text { cles }\end{array}$ & Brain targeting & {$[84]$} \\
\hline HIV & $\begin{array}{l}\text { Combination } \\
\text { antiretroviral } \\
\text { drugs; efavirenz, } \\
\text { lopinavir, } \\
\text { ritonavir }\end{array}$ & Polymeric nanoparticles & Poly-(DL-lactide-co-glycolic acid), i.e., PLGA & $\begin{array}{l}79 \% \text { drug entrapment } \\
\text { efficiency for each of the } \\
\text { three drugs, efficient } \\
\text { uptake in nonimmune } \\
\text { and immune cells, } \\
\text { higher nuclear, } \\
\text { cytoskeleton and } \\
\text { membrane drug levels in } \\
\text { HIV-1-infected H9 } \\
\text { monocytic cells, } \\
\text { inhibition of HIV } \\
\text { infection and } \\
\text { transduction with } \\
\text { IC50<31 nM for each } \\
\text { of the three drugs in } \\
\text { TZM b1 cells }\end{array}$ & {$[85]$} \\
\hline $\begin{array}{l}\text { Herpes } \\
\text { infection }\end{array}$ & Lamivudine & Polymeric nanoparticles & PLGA & $\begin{array}{l}\text { Enhanced AUC } \\
\text { High targeting }\end{array}$ & {$[86]$} \\
\hline HIV & Elvitegravir & Polymeric nanoparticles & PLGA & $\begin{array}{l}\text { Enhanced intracellular } \\
\text { uptake }\end{array}$ & [87] \\
\hline $\begin{array}{l}\text { VZV, } \\
\text { HZV, } \\
\text { HSV }\end{array}$ & Acyclovir & Mucoadhesive dendrimer & $\begin{array}{l}\text { Cyanoacrylates, polyacrylic acid, } \mathrm{Na} \\
\text { carboxymethylcellulose, hyaluronic acid, } \\
\text { hydroxypropylcellulose, polycarbophil, } \\
\text { chitosan, and gellan }\end{array}$ & Improved mucoadhesion & {$[88]$} \\
\hline $\begin{array}{l}\text { Chicken } \\
\text { pox, } \\
\text { HZV, } \\
\text { HSV }\end{array}$ & Acyclovir & Nanoemulsion & Eudragit RLPO & $\begin{array}{l}\text { Low dose } \\
\text { Minimizes side effects } \\
\text { Improves oral } \\
\text { bioavailability } \\
\text { Prolonged circulation time }\end{array}$ & [89] \\
\hline
\end{tabular}


Table 3 (continued)

\begin{tabular}{|c|c|c|c|c|c|}
\hline Diseases & Antiviral drug & $\begin{array}{l}\text { Type of nanodelivery } \\
\text { system }\end{array}$ & Lipid/polymer used as carrier & Key findings & Ref \\
\hline $\begin{array}{l}\text { VZV, } \\
\text { HZV, } \\
\text { HSV }\end{array}$ & & & & $\begin{array}{l}\text { Increased biodistribution } \\
\text { and bioavailability }\end{array}$ & \\
\hline HIV & $\begin{array}{l}\text { Nelfinavir } \\
\text { mesylate, } \\
\text { darunavir, } \\
\text { atazanavir }\end{array}$ & Nanoemulsions & $\begin{array}{l}\text { Poly-vinylpyrrolidone, HPMC, sodium } \\
\text { carboxymethyl cellulose, and methyl cellulose }\end{array}$ & $\begin{array}{l}\text { Maximizes therapeutic } \\
\quad \text { efficacy } \\
\text { Enhances solubility } \\
\text { High drug-loading capacity }\end{array}$ & [90] \\
\hline HIV & $\begin{array}{l}\text { Efavirenz, } \\
\text { saquinavir }\end{array}$ & Cyclodextrins-complexes & $\beta$-Cyclodextrin polymers & $\begin{array}{l}\text { Enhances solubility } \\
\text { Enhances physicochemical } \\
\text { properties }\end{array}$ & [91] \\
\hline $\begin{array}{l}\text { VZV, } \\
\text { HZV, } \\
\text { HSV }\end{array}$ & Acyclovir & $\begin{array}{l}\text { Mucus-penetrating } \\
\text { nanoparticles }\end{array}$ & $\begin{array}{l}\text { Poly(lactide-co-glycolide), poly(anhydrides), } \\
\text { polyethylenimine, chitosan, and polylysine }\end{array}$ & Improved mucoadhesion & [92] \\
\hline HIV & Nevirapine & Nanocrystals & $\begin{array}{l}\text { Cellulose derivatives, PVA, PVP, polyoxyethylene } \\
\text { sorbitan fatty acid esters, pluronics, poloxamers, } \\
\text { copolymers - polyoxyethylene and } \\
\text { polyoxypropylene }\end{array}$ & $\begin{array}{l}\text { Improved bioavailability } \\
\text { Prolonged and increased } \\
\text { availability of drug; } \\
\text { less excretion of the drug } \\
\text { Facilitates phagocytosis } \\
\text { and targets the spleen }\end{array}$ & [93] \\
\hline HIV & Efavirenz & Nanodispersion & PVP, PVA, HPMC, PEG & $\begin{array}{l}\text { Enhanced solubility } \\
\text { Prolonged availability of } \\
\text { drug }\end{array}$ & [72] \\
\hline HSV & Acyclovir & Nanosponges & $\begin{array}{l}\text { Hyper cross-linked polystyrenes, methyl } \\
\beta \text {-cyclodextrin, alkyloxycarbonyl cyclodextrins, } \\
\text { 2-hydroxy, propyl } \beta \text {-cyclodextrins } \\
\text { Copolymers like PVA, poly(valerolactone } \\
\text { allylvalerolactone), } \\
\text { poly(valerolactone-- } \\
\text { allylvalerolactoneoxepanedione), ethyl cellulose }\end{array}$ & $\begin{array}{l}\text { Increased solubility, } \\
\text { stability, and } \\
\text { formulation flexibility } \\
\text { Modified release of drug }\end{array}$ & [94] \\
\hline HSV & Acyclovir & Nanosponges & $\begin{array}{l}\text { Cyclodextrins, ethylcellulose, PVA, poly(valero } \\
\text { lactone allylvalero lactone), } \\
\text { poly(valerolactone-- } \\
\text { allylvalerolactoneoxepanedione) }\end{array}$ & & [95] \\
\hline HIV & Zidovudine & $\begin{array}{l}\text { Amide-functionalized } \\
\text { alginate nanoparticles }\end{array}$ & Sodium alginate & Efficient cellular uptake & [96] \\
\hline
\end{tabular}

chondroitin sulfate, dermatan sulfate, and keratan sulfate have exhibited efficient binding to the HIV envelope resulting in shielding of the viral particles and their entry into the host cells $[121,122]$. AZT conjugates with naturally occurring polymers like chitosan, dextrin, and $\mathrm{k}$-carrageenan through succinic ester linker have resulted in longer plasma half-lives and high loading of AZT. Phosphoamide-based prodrugs have been explored in which the antiviral drug stavudine was conjugated with chitosan through phosphoamide linkage. This resulted in greater antiviral potency and reduced toxicity. Synthetic polymers like vinyl esters and methacrylates have been explored for conjugation with AZT and ribavirine showing beneficial results [123]. In 2018, Andersen et al. designed albumin-polymer-drug conjugates to ensure longer residential time and lymphatic accumulation, delivering the right ratio of individual drugs of ART to primary human T cells exhibiting strong protection from HIV infection in comparison with individual ART drugs. The polymer used was N-(2hydroxypropyl) methacrylamide (PHPMA) [124].

\section{Dendrimers}

Dendrimers are highly branched, well-defined, monodisperse three-dimensional, synthetic nano-architectures, 2$10 \mathrm{~nm}$ in diameter, consisting of a central core, an inner shell made up of repeating units of the building blocks, and an outer shell containing numerous functionalities [125]. The voids and flexible spaces within dendrimers facilitate entrapment of the guest molecules, and the surface functional groups allow interaction with the desired biological targets or can carry the drug by electrostatic interaction or chemical conjugation [126]. They are synthesized by sequential addition of the building block molecules to the initiator through convergent or divergent approach, by click or lego chemistry [127]. Dendrimers have the advantages being used as theranostics and show excellent uptake by cells, longer circulation times, and enhanced solubility and stability and targeted delivery [128]. Among the commercially available dendrimers are polyamidoamine (PAMAM), poly-propylene 
imine (PPI), and poly-L-lysine dendrimers (PLL) [129]. Dendrimers are functionalized mainly with three types of molecules: carbohydrates, peptides, and anionic groups. Interestingly, these dendrimers possess inherent antimicrobial or antiviral activities. Dendrimers decorated with anionic groups interact with V3 loop of gp 120 protein and interfere with early stages of viral replication. PPI dendrimers with randomly sulfated galactose residues and PLL dendrimers with sulfated galactose and cellobiose residues have demonstrated good antiviral activity [130]. In recent times, glycodendropeptide with up to 16 peptides and 9 mannose units emerged as a promising tool for optimizing immune response against viral infections [131]. The most successful PLL dendrimer (VivaGel) functionalized with naphthalene disulfonate groups is currently undergoing phase I/II clinical trials for vaginal microbicidal activity [132].

Polyanionic carbosilane dendrimers (PCDs) have been explored against HIV and herpes simplex virus (HSV)-2 as topical microbicides [133]. They are shown to inhibit viral entry fusion process and prevent these sexually transmitted infections. Some of them bind directly to HSV-2 virus, inactivating it, and some adhere to the host cell-surface proteins. They exhibit synergistic activity with antiviral drugs like acyclovir and tenofovir against HSV-2 in vitro. The combination of PCDs with tenofovir and maraviroc as monotherapy has shown to enhance efficacy, reduce doses and side effects, and minimize emergence of multidrug-resistant mutants of HIV (mutants resistant to nucleoside reverse transcriptase inhibitors) [134]. This is attributed to the multiple mechanism of action of polyanionic carbosilane dendrimers which includes binding to viral gp120 as well as also with the CD4 and 740 CCR5/CXCR4 receptors expressed on the host cell surface. In another study, PCDs have shown to prevent HCV infection in cell culture [135]. In a study carried out by Landers et al., sialic acid-functionalized PAMAM dendrimers were shown to prevent mice from influenza pneumonitis [136].

In another study carried out by García-Gallego et al., metal complexes of carboxylated and sulfated PPI dendrimers with ethylene diamino core demonstrated dual therapeuticpreventive activity against HIV-1 infection by inhibiting internalization of HIV-1 into the epithelial cells. In addition, these metallodendrimers also prevented the entry of virus in peripheral blood mononuclear cells taken as a model for second barrier against HIV infection [137]. Ammonium terminated amphiphilic Janus dendrimers were shown to selfassemble in water to form micelles capable of carrying the antiviral drug camptothecin. These drug-loaded dendrimers were found to be highly efficacious against replicating HCV at lower working concentrations and hence displayed low toxicity and better therapeutic index than the free drug [138]. Biodegradable poly(phosphor-hydrazone) dendrimers with end phosphoric acid functionalities and alkyl chains have been proposed for anti-HIV activity [139]. Thiolated dendrimers loaded with acyclovir were developed by Yandrapu et al. which exhibited sustained release and mucoadhesion [140].

Recently, Martínez-Gualda et al. synthesized a new class of dendrimers which are pentaerythritol derivatives containing multiple aromatic and nonaromatic amino acids on the periphery using the convergent approach. These dendrimers were found to exhibit dual activity against HIV and enterovirus 71 (EV71) responsible for hand-foot-and-mouth disease prevalent among children below 6 years of age. They found dendrimer with peripheral $\mathrm{N}$-methyl tryptophan to be most potent against HIV-1 and that with tyrosine to be most active against EV71 [141].

\section{Nanocapsules}

A nanocapsule consists of nanosized structure $(50-300 \mathrm{~nm})$ having a core and a shell. The drug is confined to the inner core, surrounded by the polymeric shell. Nanocapsules exhibit advantages of high drug loading, controlled release, and targeted drug delivery. They are usually prepared by polymer coating, layer-by-layer method, nanoprecipitation, emulsiondiffusion, emulsion coacervation, emulsion evaporation, and double emulsification [142]. In a study, nanocapsule consisting of poly(iso-butylcyanoacrylate) core, entrapping azidothymidine-triphosphate (AZT-TP) and polyethyleneimine which forms the shell, was designed to directly deliver (AZT-TP) into the cytoplasm [143].

\section{Nanospheres}

Nanospheres are smaller spherical structures of 10-200 nm diameter, where the drug is uniformly dispersed in the matrix system. This type of nanocarrier shows enhanced sizedependent characteristics, having the capability to prevent the drug from undergoing degradation. In addition, rapid drug clearance is observed due to smaller size. It offers site-specific delivery and the required drug release profiles. Recommended preparation techniques used are solvent evaporation, polymerization solvent displacement techniques, and phase inversion temperature methods [144]. Chitosan nanospheres loaded with acyclovir were synthesized using modified nanoemulsion template method for topical treatment of herpes. The spheres were of the average size of $200 \mathrm{~nm}$ and showed better permeation in in vitro skin permeation studies and higher potency against HSV-1 and HSV-2 than the free acyclovir itself [145].

\section{Cyclodextrin-based delivery systems}

Cyclodextrins (CDs) are cyclic oligosaccharides made of six to twelve $\alpha$-D-glucopyranose monomers linked by $\alpha 1-4$ linkages having exceptional hydrophobic interior surfaces and hydrophilic rims with primary and secondary $-\mathrm{OH}$ groups. 
This type of molecular construct entraps the drug in a bucketshaped cavity, thereby increasing the solubility of the drug and protecting the drug from degradation. Due to this, CDs become preferred delivery system for drugs [146]. The common native or parent cyclodextrins are $\alpha-\mathrm{CD}, \beta-\mathrm{CD}$, and $\gamma$ $\mathrm{CD}$ comprising of 6,7 , and 8 glycopyranose units and molecular weights of 972, 1135, and $1297 \mathrm{Da}$, respectively [147]. These CDs have a homogeneous crystalline structure offering numerous advantages like their unique ability to interact with a range of organic and inorganic lipophilic molecules and form inclusion complexes. But their use is restricted due to low solubility of the CDs. Thus, alteration in CDs is being made to make them more suitable for their application in the pharmaceutical industry [148]. $\beta-C D$ and its derivatives are more widely used than $\alpha$-CD and $\gamma$-CD because of their safety and ease of production. The structural framework of $\beta-C D$ is attractive with a height of 750-800 pm, external diameter of $1530 \mathrm{pm}$, internal diameter of 600-680 pm, and cavity volume of $260-265 \AA^{3}$ [149]. These dimensions make the most ideal hosts for the formation of inclusion complexes. Chemical and enzymatic modifications of macrocycle 1 in $\mathrm{CD}$ derivatives that self-assemble in aqueous solutions provide different shapes of supramolecular nano-assemblies (vesicles, micelles, nanorods, nanospheres, and other kinds of nanoparticles and liquid crystalline structures of 30-500 nm in size depending on the concentration which are very useful for different types of nanodelivery systems) [150]. One of the common problems encountered with antiviral drugs is their poor bioavailability. A similar problem was found with the drug saquanavir. Couvreur and Vauthier formulated CDs loaded with saquanavir using poly(alkylcyanoacrylate) to deal with the issue. This improved solubility in water by 400 -fold. Also, it was speculated that saquanavir could now bypass the efflux mechanism of P-gp, preventing its resistance [151]. Similarly, in another study, acyclovir was loaded with CDs using the copolymer such as Eudragit RLPO ${ }^{\circledR}$, and on evaluation, it was found that intracellular uptake of the drug increased and it had sustained drug release over a period of $24 \mathrm{~h}$ [145]. Thus, by utilizing other drugs, CDs with different polymers can be formulated to increase the intracellular concentration of the drug.

\section{Antimicrobial peptides with antiviral activities}

Several peptides from natural (includes plants, arthropod venoms, amphibian skin, mammalian tissues) and microbial sources (includes bacteria, algae, and fungi) have been known to possess broad-spectrum antiviral activities. Various mechanisms, either targeting the virus or the host cells have been proposed for their antiviral activities. Some examples include magainin 1 and 2, dermaseptin S4 and temporin B (from frog skin), clavanin (from marine source), latarcin, protegrin (from swine WBCs), cyclotides (from plants), cecropin (from moth), defensins and cathelicidins (from mammals), and poly- $\gamma$ glutamic acid (from bacteria) exhibiting potent activity against various viruses like HIV, H1N1, DENV, and HCV $[152,153]$. In addition, certain peptides, rationally designed and synthesized depending on the structure of the viral protein and its interaction with the host cell protein, have shown great potential as antiviral agents. Enfuvirtide is the first peptide antiviral drug approved against HIV [154]. Despite various advantages, various hurdles in their production, shorter half-life, and poor bioavailability have limited their use as antiviral agents. Nanotechnology-based solutions have been explored for the delivery of antiviral peptides. Peptide-nanoparticle conjugate systems have been extensively studied. Emileh et al. have reported gold nanoparticle-peptide triazole conjugates to be active against HIV-1 by disrupting the interactions between host receptor proteins and trimeric envelope spike glycoprotein of virus [155]. Recently, Alghrair et al. functionalized silver and gold nanoparticles with an antiviral peptide FluPep and reported increased antiviral potency against influenza A virus [156].

Table 3 compiles a list of polymer-based nanoformulations for antiviral treatment.

\section{Carbon-based nanoformulation}

Carbon-based nanoformulations are comprise of carbon nanotubes, graphene oxide nanoparticles, and fullerenes.

\section{Carbon nanotubes}

Carbon nanotubes (CNTs) are cylindrical-shaped hollow nanomaterials, viewed as tubes made by rolling up of planar graphene sheets. They can be viewed as coming from the rolling up of a graphene sheet, named as single-walled carbon nanotubes (SWCNTs), or a series of concentric rolled-up graphene sheets termed as multi-walled carbon nanotubes (MWCNTs) [157]. The cylindrical structure is capped with fullerene sheets on one end or both ends. The $\mathrm{sp}^{2}$-hybridized carbon atoms in graphene sheets impart a unique strength to CNTs. In addition, they display other unique characteristics like high aspect ratio, high surface area, cell penetration capacity, and ultralight weight [158]. The chemical vapor deposition (CVD) technique, laser-ablation technique, and electric arc-discharge techniques are commonly employed for the preparation of carbon nanotubes [159]. Though CNTs are widely explored for delivering chemotherapeutic agents at the target site, their overall application in the biomedical field is limited due to pulmonary toxicity and high hydrophobicity [160]. The proposed mechanisms for toxicity are uptaken by macrophages with subsequent generation of ROS and inflammatory mediators. However, functionalized CNTs have shown decreased toxicity and increased biodegradability. CNTs can be decorated with peptides, carbohydrates, and 
polymers and can be used for targeted therapy, when needed [161]. In one study, Kumar et al. stated about protoporphyrin IX (PPIX)-conjugated multi-walled nanotubes (MWNTs) and its ability to treat influenza using photodynamic therapy. It was found that in the presence of visible light, PPIXMWNT may indulge in mechanisms like RNA strand breakage, protein oxidation, or protein-RNA cross-linking caused by reactive oxygen species (singlet oxygen and superoxide anion) leading to inactivation of the influenza viral strain. Probing into the inactivation mechanism of carbon nanotubes, they concluded that PPIX-MWNTs can be used for treating any viral infection as it displays nonspecificity in treating viral diseases. Also, PPIX-MWNT can be easily recovered through filtration and reused. Due to its multitarget mechanisms of antiviral action, it was proposed that PPIX-MWNTs have less chances of development of drug resistance [162].

Nanostructures have shown antiviral effect in respiratory syncytial virus, a virus causing severe bronchitis and asthma. The treatment is generally done by combining nanoparticles and gene-silencing technologies. In a novel approach, MWCNTs were functionalized with recombinant dengue virus 3 envelop proteins. This induced significant immune responses in mice [163]. Similarly, conjugation of functionalized CNTs with B and T cell peptide epitopes could generate a multivalent system that was able to induce a strong immune response; thus, CNTs were considered to be good candidates for vaccine delivery [164]. Further, functionalized CNTs were used for the transport of peptides (such as foot-and-mouth virus peptide) for vaccination [165].

\section{Graphene}

One of the most promising carbon-based nanomaterials with great potential for antiviral application is graphene. Graphene (G) is a two-dimensional (2-D) planar sheet of hexagonally arranged $\mathrm{sp}^{2}$-hybridized carbon atoms obtained from its threedimensional (3-D) material of graphite [166]. It is chemically oxidized to graphene oxide (GO) to acquire oxygen bearing functional groups like hydroxyl, epoxide, and carboxylic acids [167]. Graphene-based nanomaterials (GBNs) have high surface area, high loading capacity, and superior mechanical strength which make them attractive candidates for carrying antiviral agents [168]. The oxygen-containing functional groups allow surface functionalization and conjugation strategies and show biocompatibility, reduced toxicity, and good dispersibility [169]. The amphiphilicity of GO makes the incorporation of hydrophilic as well as hydrophobic moieties possible [170]. In addition, these functional groups also provide attachment sites for various biological molecules like proteins, DNA, and RNA [171].

Recently, Pokhrel et al. studied the interactions between graphene and VP40 (viral matrix protein) of Ebola virus using molecular dynamics simulations and graphene pelleting assay.
Graphene was found to interact strongly with VP-40 at various interfaces crucial for the formation of the viral matrix. They proposed the use of graphene-based nanoparticle solutions as disinfectant to prevent the Ebola epidemic [172].

In another study, 18 sulfonated magnetic nanoparticles were anchored onto reduced graphene oxide (SMRGO) sheets and used to trap and destroy HSV-1 photothermally, upon their irradiation with near-infrared light. It was found to be effective against 28 viral infections including HSV. It was found that SMRGO has higher entrapment efficiencies in comparison to magnetic nanoparticles due to increased entrapping efficiency, larger surface area, unique sheet-like structure, and outstanding photothermal characteristics shown by graphene [173].

\section{Fullerenes}

Fullerenes are among the first discoveries in symmetric carbon nanostructures and have received considerable attention in the case of antiviral research. Fullerenes are comprised fully of carbon atoms forming a nanosized caged hollow sphere. Buckminster fullerene (C60), also known as buckyball, is the most common form of fullerenes with 60 carbon atoms arranged in a spherical structure showing high symmetry [174]. Due to their unique architecture, immense scope of derivatization, free radical scavenging activity, and low toxicity, they are widely studied for drug delivery and antimicrobial and antiviral activities [175].

Fullerenes were found to fit inside the hydrophobic cavity of HIV proteases and inhibit HIV replication [176]. Structureactivity relationship studies revealed trans-position of substitutions and positive charge near the cage to be important for antiviral activity. Fulleropyrolidines with two ammonium groups have been shown to be active against HIV-1 and HIV-2 [177]. Also, fullerene C60 derivatized with two or more solubilizing side chains has been active when tested in CEM culture cells infected with HIV-1 and HIV-2 [178]. Additionally, amino-acid derivatives of fullerene C60 are found to inhibit HIV and HCV replication [179, 180].

Few studies aimed at screening fullerene derivatives for anti-influenza activity. Shoji et al. screened 12 fullerene derivatives for in vitro PA endonuclease inhibition. PA represents the subunit of influenza A RNA polymerase which demonstrates endonuclease activity. It was found that 8 fullerene derivatives demonstrated endonuclease inhibiting potential. In the MDCK cell culture system, these fullerene derivatives inhibited influenza A virus infection and expression of viral nucleoprotein [181].

Few of the studies also aimed at synthesizing anti-influenza fullerenes and evaluating their effectiveness against the influenza virus. Tollas and colleagues also prepared a fullerene conjugate having a thiosialosyl-a(2,6)-galactose disaccharide and evaluated to understand the multimeric interaction of a 
sialocluster with influenza virus NA and HA. Results revealed that these fullerene derivatives did not target HA but was able to target influenza NA slightly [182].

Table 4 gives an account of various carbon-based nanoformulations for antiviral treatment.

\section{Inorganic-based nanoformulations}

Quantum dots (QDs) $(2-10 \mathrm{~nm})$ are semiconductor nanocrystals having the shape of dots. They are comprised of a semiconductor core, overcoated by a shell, and a cap leading to improved solubility in aqueous buffers [190]. Fundamental semiconducting character and unique optical and electronic properties are attributed to the presence of the inorganic core consisting of semiconducting materials like silicon, cadmium selenide, cadmium sulfide, or indium arsenide [191]. Quantum dots find interesting applications in biomedical imaging due to its limited light scattering, narrow emission bands, and low tissue penetration. Quantum dots have been widely explored as theranostic platforms for simultaneous sensing, imaging, and therapy [192]. The advantages of quantum dots as a drug carrier system include improved bioavailability and stability of drugs, increased circulation times, active targeting, and localized therapy. In addition to this, QDs can be surface modified with targeting ligands [193, 194]. Yong et al. utilized saquinavir and transferrin (Tf)-conjugated quantum dots for the treatment of HIV. In vitro studies demonstrated that higher concentrations of saquinavir were able to cross the BBB by this method [195].

Metal and metal oxide nanoparticles have been widely explored for their antiviral activity. Among the various metal nanoparticles showing high efficacy are silver and gold, and among the various metal oxides are $\mathrm{CuO}, \mathrm{SiO}_{2}, \mathrm{TiO}_{2}$, and $\mathrm{CeO}_{2}$. These nanoparticles have shown great efficacy against a broad spectrum of viruses like influenza (H3N2 and H1N1), HBV, HSV, HIV-1, HSV, dengue virus type-2, foot-andmouth disease virus, and vesicular stomatitis virus [196].

Metal nanoparticles by virtue of their unique shape, size, structure, and local-field enhancement action can interact with viral surface proteins through Kazimir interaction and van der Waals forces causing its inactivation [197]. A variety of surface functionalizations with silane or thiol groups have shown to enhance interaction with biomolecules, affecting viral internalization in cells as well as the release of the drug molecule. Few researchers have also explored further grafting on functionalized metal nanoparticles in order to enhance their efficacy and selectivity [198].

\section{Gold nanoparticles}

Gold nanoparticles (AuNPs) are colloids of nanosized particles of gold. AuNPs show special optical properties in the presence of light. When AuNP comes in contact with light, the oscillating electromagnetic field of light triggers coherent oscillation of the free gold electrons [199]. This electron oscillation about the particle surface is responsible for a charge separation with regard to the ionic lattice, leading to a dipole oscillation in the path of the electric field of light. However, when the amplitude of the oscillation becomes maximum at a particular frequency, photons get confined to a small particle size and leads to a special phenomenon known as surface plasmon resonance (SPR) [200]. This SPR boosts all the radiative and nonradiative characteristics of the nanoparticles and, thus, has extensive application in areas of biological imaging, electronics, and materials science [200].

In 2015, Bayo et al. demonstrated that AuNP could enter the cells of various types like lymphocytes, macrophages, and brain microendothelial cells where HIV is known to replicate. Further, they modified raltegravir (RAL) by introducing a thiol group that served as a linker between RAL and AuNP. These particles inhibited HIV replication after penetrating inside infected primary PBMCs (peripheral blood mononuclear cells) exhausted from CD8+. Surprisingly, when the concentration of RAL was increased with the expectation of displaying high antiviral activity, it was found that anti-HIV activity was impaired. The experiment showed positive results when a low concentration of RAL was loaded into AuNP. The authors also performed an experiment using free AuNP and the results proved that it does not have any antiviral activity. So it was just a low concentration of RAL-loaded AuNP which turns it into an active compound having inhibitory action against HIV [201].

Small interfering RNAs (siRNAs) which can target particular viral gene can be employed in the treatment of dengue. However, siRNAs are prone to degradation by serum nucleases and to rapid elimination on account of its small size and anionic character. Paul et al. conjugated siRNAs with AuNPs and found that the complex had enhanced stability and could reduce dengue virus replication and the release of infectious virion in both pre- and post-infection conditions [202].

A breakthrough in the arena of gold nanoparticles was the design and synthesis of long and flexible linkers which mimicked heparan sulfate proteoglycans (HSPG), a target for viral attachment ligand. This allowed effective attachment of the virus to HSPG, generating strong forces that eventually lead to viral deformation. The mechanism was proposed by researchers on the basis of molecular dynamics simulations, electron microscopy images, and virucidal assays. These nanoparticles were nontoxic and effective against a broad range of viruses like HSV, human papilloma virus, respiratory syncytial virus (RSV), dengue, and lentivirus. Additionally, they were found to be active ex vivo in human cervicovaginal histocultures infected by HSV-2 and in vivo in mice infected with RSV [203].

Recently, Halder et al. synthesized highly monodispersed gold nanoparticles, stabilized by gallic acid. Reduction of 
Table 4 Carbon-based nanoformulation

\begin{tabular}{|c|c|c|c|c|c|c|}
\hline Diseases & $\begin{array}{l}\text { Antiviral } \\
\text { drug }\end{array}$ & Type of nanodelivery system & Composition & $\begin{array}{l}\text { Problems } \\
\text { encountered }\end{array}$ & Key findings & Ref \\
\hline HIV & Lamivudine & CNT & $\begin{array}{l}\text { Isobutane, nitric acid, } \\
\text { and sulfuric acid }\end{array}$ & $\begin{array}{l}\text { Decreased } \\
\quad \text { drug } \\
\text { solubility } \\
\text { Increased } \\
\quad \text { drug } \\
\text { resistance }\end{array}$ & $\begin{array}{l}\text { Improved hydrophilicity } \\
\text { Improved dispersibility }\end{array}$ & [183] \\
\hline $\begin{array}{l}\text { Respiratory } \\
\text { syncitial virus }\end{array}$ & Curcumin & $\begin{array}{l}\text { B-cyclodextrin-functionalized } \\
\text { graphene oxide }\end{array}$ & - & - & $\begin{array}{l}\text { Highly efficient inhibition of } \\
\text { RSV by inhibiting the viral } \\
\text { attachment. Exhibited } \\
\text { prophylactic as well as } \\
\text { therapeutic effects toward the } \\
\text { virus }\end{array}$ & [184] \\
\hline Pseudorabies virus & - & $\begin{array}{l}\text { PVP-conjugated graphene } \\
\text { oxide }\end{array}$ & - & - & $\begin{array}{l}\text { Improved antiviral activity by } \\
\text { mechanism of structural } \\
\text { destruction of the virus prior to } \\
\text { viral entry }\end{array}$ & [185] \\
\hline $\begin{array}{l}\text { Nonenveloped } \\
\text { virus (infectious } \\
\text { bursal virus) } \\
\text { and enveloped } \\
\text { feline } \\
\text { coronavirus }\end{array}$ & - & $\begin{array}{l}\text { Graphene-silver } \\
\text { nanocomposites }\end{array}$ & - & - & $\begin{array}{l}\text { Improved antiviral activity of } \\
\mathrm{GO}-\mathrm{Ag} \text { nanocomposites as } \\
\text { compared to GO nanocom- } \\
\text { posites }\end{array}$ & - \\
\hline HIV & $\begin{array}{l}\text { CHI499 } \\
\text { CDF119 }\end{array}$ & Graphene quantum dots & - & $\begin{array}{l}\text { Decreased } \\
\text { drug } \\
\text { solubility in } \\
\text { water }\end{array}$ & Increased drug solubility in water & [186] \\
\hline HIV & - & Cationic fullerene derivatives & - & $\begin{array}{l}\text { Decreased } \\
\quad \text { solubility } \\
\text { of } \\
\text { fullerenes }\end{array}$ & $\begin{array}{l}\text { Increased selectivity of viral } \\
\text { inhibition }\end{array}$ & [180] \\
\hline Ebola & - & Fullerenes & Mannose & $\begin{array}{l}\text { Decreased } \\
\text { develop- } \\
\text { ment of } \\
\text { resistance } \\
\text { due to viral } \\
\text { mutations }\end{array}$ & Increased antiviral activity & [187] \\
\hline Influenza virus & - & Fullerene derivatives & - & - & $\begin{array}{l}\text { Antiviral activity through } \\
\text { inhibition of endonuclease } \\
\text { activity }\end{array}$ & [181] \\
\hline HIV & - & Fullerenes & $\begin{array}{l}\text { Water-soluble } \\
\text { polycarboxylic acid } \\
\text { derivative of C60 } \\
\text { fullerene loaded with } \\
\text { 3,4-dichlorophenyl } \\
\text { units }\end{array}$ & - & Antiviral activity & [188] \\
\hline $\mathrm{HCV}$ and $\mathrm{HSV}$ & - & Carbon nanodot & - & $\begin{array}{l}\text { Decreased } \\
\text { antiviral } \\
\text { activity }\end{array}$ & Increased antiviral activity & [189] \\
\hline
\end{tabular}

$\mathrm{AuCl}_{4}$ using gallic acid was carried out using ultrasoundinduced sonication which produced spherical nanoparticles in the range of 7-8 $\mathrm{nm}$. These nanoparticles selectively inhibited HSV with EC50 of $32.3 \mu \mathrm{M}$ in HSV-1 and $38.6 \mu \mathrm{M}$ in HSV-2 with better safety profile compared to acyclovir. Prevention of viral cell attachment and penetration was proposed as a mechanism of action of these nanoparticles [204].

\section{Silver nanoparticles}

Silver metal possesses intrinsic antimicrobial activity due to its ability to interact with respiratory chain and electron transport chain enzymes and bacterial DNA. It has been extensively studied since ancient times for fighting infections [205]. Silver nanoparticles, on account of its small size and enormous surface area, facilitate rapid dissolution and have shown 
promising activity against a wide spectrum of viruses [206]. They demonstrate less chances of development of resistance on account of multiplicity of targets they act upon [207]. Nanoparticles of silver possess their own unique properties with regard to chemical stability, catalytic activity, high conductivity, and localized surface plasma resonance enabling researchers to envisage the implication of using AgNPs in disease therapeutics [208].

Galdiero et al. were the first authors to describe the antiviral activity of silver nanoparticles against HIV-1. They studied AgNP with three different surface functionalities: foamy carbon-coated AgNPs, poly(N-vinyl-2-pyrrolidone) (PVP)-coated AgNPs synthesized using glycerol as a reducing agent, and BSA-conjugated AgNPs. They proposed that the interaction between these NPs and the HIV viral surface glycoprotein gp120 was size dependent, as only the NPs in the size range of $1-10 \mathrm{~nm}$ were able to bind to the virus. BSA- and PVP-coated nanoparticles demonstrated lower inhibitory activity than silver nanoparticles released from the carbon matrix in in vitro assays on laboratory-adapted HIV-1 strain. AgNPs were shown to block the gp120-CD4 interaction. Additionally, they also were proved to inhibit the postentry stages of infection by complexing with $\mathrm{S}$ and $\mathrm{O}$ of thiols and phosphates on amino acids and nucleic acid or directly bind to RNA or DNA, thus reducing the rate of reverse transcription [208]. Baram Pinto et al. synthesized mercaptoethane sulfonate (MES)-functionalized $\mathrm{Au}$ and AgNPs against HSV with a strategy to mimic heparan sulfate, present on the cell surface so that they compete for binding of the virus onto the cell. They inhibited HSV-1 infections by blocking the attachment and entry of the virus into the cell [209].

AgNPs have been investigated for their activity against H1N1 influenza virus. Xiang et al. prepared and studied the activity of AgNP on H1N1 influenza A virus-induced apoptosis in MDCK cells [210]. With the help of hemagglutination inhibition test, they found that AgNPs reduced or completely inhibited agglutination of RBCs. During the MTT assay, they found that the antiviral activity of AgNPs continued for a prolonged period. Surface-decorated AgNPs were explored by Li et al. They synthesized the AgNPs' surface decorated with oseltamivir and its anti-H1N1 activity through inhibition of neuraminidase and hemagglutinin activity, leading to the prevention of attachment of H1N1 to the host cells. They proposed interference with ROS-mediated signaling pathway as a mechanism of anti-H1N1 activity [211]. Similar studies were carried out by the same research group on $\mathrm{AgNPs}$ decorated with amantadine [211]. Moreover, it was seen that reactive oxygen species (ROS) are formed either on the surface of AgNPs or via release of free silver ions under specific conditions. This ROS induces the cell death of either microbial cells or mammalian cells, depicting a unique antibacterial and antifungal attribute of AgNPs [212].
Similarly, another study highlighted the use of gold and silver nanoparticles for effective delivery of antiviral peptide FluPep. Its conjugation with the noble metal nanoparticles enhanced the solubility as well as its antiviral activity. The authors proposed $\mathrm{Ag}$ and AuNPs as an effective strategy for delivering the therapeutic peptide [213].

In another study, modification of silver nanoparticles with tannic acid was able to reduce HSV-2 infections and inflammation in vitro and in vivo. The authors proposed binding of tannic acid with glycoproteins present on the surface of infectious virions as a mechanism for prevention of entry and spread to host cells. The anti-HSV-2 activity of tannic acidmodified AgNP (TAAgNP) was more profound than tannic acid alone, and the direct interaction between tannic acidmodified AgNP with virions was essential for the activity. Pretreatment of host cells with TAAgNPs did not inhibit the entry of the virus into the host cells. Furthermore, the TAAgNPs having a particle size of $33 \mathrm{~nm}$ not only showed better toxicity/effectiveness ratio but also reduced inflammation in an in vivo mouse model of HSV-2 infection [214].

\section{Zinc oxide nanoparticles}

Antione et al. designed and synthesized zinc oxide tetrapod nanoparticles (ZOTEN) with engineered oxygen vacancies using the flame transport synthesis approach. This was achieved by burning mixture of zinc particles, polyvinyl butyrol particles, and ethanol in a furnace at $900{ }^{\circ} \mathrm{C}$, where $\mathrm{Zn}$ in vapor form combines with available oxygen resulting in uniform nucleation and growth of the same and forming tetrapod-like structures. Nano-immunotherapy is one more way in which HSV-2 can be treated. The activity of ZOTEN was tested in female mice. It was seen that clinical signs of vaginal infection was greatly improved with use of this therapy. ZOTEN has high ability to trap HSV-2 virus and then it acts by increasing the presentation of the virus to mucosal APCs, which boosts T cell-mediated and Ab-mediated responses to the HSV-2 infection and, thus, suppresses viral activity [215].

Despite potential advantages, the use of inorganic nanoparticles has become limited due to its potential toxicity. Numerous studies have proven to cause toxicity as a result of administration of inorganic nanoparticles [216, 217]. Examination of toxicity-related aspects with regard to inorganic nanoparticles is being done by researchers.

Table 5 presents various inorganic material-based nanodelivery systems used for the treatment of viral infections.

\section{Lipid-polymer hybrid nanoformulations}

The inability of a single drug to completely cure viral infection necessitates a multidrug therapy approach. In order to deliver 
two or more chemotherapeutic drugs with different physicochemical properties in a single delivery vehicle, lipid-polymer hybrid nanoparticles are developed [227]. This becomes possible due to the amphiphilic nature of polymers and lipids which helps in the development of stable nanodelivery systems for the simultaneous delivery of several hydrophobic/ hydrophilic drugs [228]. They offer benefits like high drugloading capacity, stealth characteristics, high stability, biocompatibility, prolonged circulation time, and controlled drug release properties. The use of polymers allowed the systems too be surface functionalized and achieve targeted delivery [229]. On account of several benefits offered by the use of lipid and polymer, several nanocarrier systems have been developed. They include the following various polymer-lipid hybrid nanoformulations which can be used for the above purpose: polymer core-lipid shell nanoparticles, hollow core/shell lipid-polymer-lipid hybrid nanoparticles, lipid bilayer-coated polymeric nanoparticles, and polymer-caged nanoparticles.

Polymer core-lipid shell nanoparticle consists of an inner polymeric core enclosed in one or more outer layers of lipid membranes (lipid-PEG and lipoidal shell). Hollow core/shell lipid-polymer-lipid hybrid nanoparticles are comprised of 3 layers - a hollow core bordered by a lipid layer bearing a positive charge, a middle hydrophobic polymeric layer, and then surrounded by a lipid-PEG layer. Lipid bilayer-coated polymeric nanoparticles consist of a lipid bilayer coated with polymer. Polymer-caged nanoparticles are actually liposomes with their surface modified by cross-linked polymers for better functionality (as shown in Fig. 3) [230]. Various methods like emulsification solvent evaporation, nanoprecipitation, high pressure homogenization, and self-assembly

Table 5 Inorganic-based nanoformulation

\begin{tabular}{|c|c|c|c|c|c|c|}
\hline Diseases & Antiviral drug & $\begin{array}{l}\text { Type of } \\
\text { nanodelivery system }\end{array}$ & Composition & $\begin{array}{l}\text { Problems } \\
\text { encountered }\end{array}$ & Key findings & Ref \\
\hline Influenza & Zanamivir & $\begin{array}{l}\text { Selenium } \\
\text { nanoparticles }\end{array}$ & $\begin{array}{l}\text { PVP, } \\
\text { polyethylenimine, } \\
\text { polyacrylamide }\end{array}$ & Low oral absorption & Increase in cell viability & [218] \\
\hline Influenza & Amantadine & SeNPs & $\mathrm{Na}_{2} \mathrm{SeO}$ & $\begin{array}{l}\text { Tendency to } \\
\text { develop drug } \\
\text { resistance }\end{array}$ & High anti-influenza activity & [219] \\
\hline $\mathrm{HCV}$ & - & Copper oxide NP & $\begin{array}{l}\text { Cupric sulfate, } \\
\text { HCVcc/Huh7.5.1 } \\
\text { cell culture }\end{array}$ & & $\begin{array}{l}\text { Inhibition of HCV at noncytotoxic } \\
\text { concentration, by blocking } \\
\text { attachment and entry of virus into } \\
\text { the cells }\end{array}$ & [220] \\
\hline HIV & - & $\begin{array}{l}\text { Gold NP stabilized } \\
\text { by polyethylene } \\
\text { glycol }\end{array}$ & $\begin{array}{l}\text { HeLa-CD4-LTR-B-gal } \\
\text { cell line }\end{array}$ & - & $\begin{array}{l}\text { Inhibits the HIV entry by binding with } \\
\text { gp120 and prevents CD4 } \\
\text { attachment, } \\
\text { IC } 50=1.12 \pm 0.05 \mathrm{mg} / \mathrm{mL}\end{array}$ & [221] \\
\hline RSV & - & $\begin{array}{l}\text { Gold NPs } \\
\text { functionalized } \\
\text { with anti-RSV } \\
\text { synthetic peptides }\end{array}$ & Hep2 cells & - & Inhibition of RSV replication & [222] \\
\hline HIV & Zidovudine & $\begin{array}{l}\text { Gold NPs stabilized } \\
\text { and reduced by } \\
\text { pectin }\end{array}$ & Macrophages & Increased toxicity & $\begin{array}{l}\text { Decreased toxicity, stable under } \\
\text { varying pH and electrolyte } \\
\text { conditions, high uptake by } \\
\text { macrophages }\end{array}$ & [223] \\
\hline HIV & Azidothymidine & $\begin{array}{l}\text { Gold nanocargos } \\
\text { functionalized } \\
\text { with L-cysteine }\end{array}$ & $\begin{array}{l}\text { HIV-1 Ba-L virus, cys- } \\
\text { teine }\end{array}$ & - & $\begin{array}{l}\text { Provides biocompatible and stable } \\
\text { drug delivery }\end{array}$ & [224] \\
\hline Dengue & - & AgNPs & $\begin{array}{l}\text { Salicylic acid, } \\
\text { 3,5-dinitrosalicylic } \\
\text { acid }\end{array}$ & $\begin{array}{l}\text { Less drugs available } \\
\text { in market to } \\
\text { potentially treat } \\
\text { dengue } \\
\text { High cost of drugs }\end{array}$ & $\begin{array}{l}\text { Eco-friendly insecticide, low dose of } \\
\text { drug required }\end{array}$ & [225] \\
\hline $\begin{array}{l}\text { Herpes } \\
\text { simplex } \\
\text { virus } \\
\text { (HSV) in- } \\
\text { fections }\end{array}$ & - & $\begin{array}{l}\text { Highly } \\
\text { monodispersed } \\
\text { AgNPs }\end{array}$ & Gallic acid & $\begin{array}{l}\text { Tendency to } \\
\text { develop drug } \\
\text { resistance } \\
\text { Safety issues }\end{array}$ & $\begin{array}{l}\text { High ant-HSV activity } \\
\text { Safer alternative drug }\end{array}$ & [204] \\
\hline $\begin{array}{l}\text { H1N1 } \\
\text { influenza } \\
\text { A virus }\end{array}$ & - & $\begin{array}{l}\text { AgNP-chitosan } \\
\text { composites }\end{array}$ & - & - & Appreciable antiviral activity & [226] \\
\hline
\end{tabular}


nanoprecipitation have been used for the preparation of these systems [227]. Joshy and colleagues formulated zidovudineloaded polyvinylpyrrolidone (PVP)/stearic (SA)-polyethylene glycol (PEG) nanoparticles (PSNPs) in order to increase the short half-life of the drug. Results illustrated positive outcomes with maximum drug-loading and encapsulation efficiencies were observed [231].

Table 6 represents various lipid-polymer hybrid systems for antiviral therapy.

\section{Biomimetic lipid-polymer hybrid nanoformulation}

Biomimetic lipid-polymer hybrid (LPH)-NPs are formed by modifying the surface of NPs with ligands that mimic cell surface proteins. These LPH-NPs offer distinct advantages like long circulation time and cell-specific targeting, biocompatibility, increased efficacy, and attenuation of drug resistance [236]. The approach is becoming increasingly popular in nanotherapeutics as well as in nanovaccines [237]. Two strategies under this category are virus-like particles (VLPs) and virosomes. VLPs are self-assembled particles that are formed by incorporating the virus-derived capsid or envelope proteins into various naturally occurring proteins like ferritin, lumazine synthase, and encapsulin, displaying an advantage of precise structure and defined surface functionalities [238]. Virosomes are virus-like particles having a modified phospholipid bilayer to incorporate the viral envelope glycoproteins like HA or NA. This vesicle is comprised of a reconstituted virus envelope lacking nucleocapsid (includes genetic content of the source virus) [239]. The unique properties of these vesicles make them suitable to carry diverse payloads including drugs, antibodies, proteins, and contrast agents. These systems hold considerable promise as they enable cellular entry, escape endolysosomal entrapment, and achieve targeted delivery [240]. It is proposed that the risk of potential immunogenicity of such systems can be addressed by incorporating PEG and other targeting moieties in a bilipid layer of virosomes [241]. Kanekiyo et al. genetically fused influenza HA protein with naturally occurring protein ferritin. This fusion glycoprotein could spontaneously self-assemble to create nanoparticles exposing HA trimeric spikes on their surfaces. This designed vaccine elicited more potent and broader response than the conventional influenza vaccine [242]. In another study, a self-assembling protein was rationally designed in silico to present the antigenic prefusion stabilized F-protein from RSV. This was further synthesized to form selfassembled NP which had the advantages of having optimized stability and immunogenicity [243].

\section{Stimuli-based lipid-polymer hybrid nanoformulation}

Stimuli-responsive LPH-NPs (SRNPs) have the capacity to increase the therapeutic efficacy and to reduce the side effects of drugs by controlling the release of the encapsulated drug exactly at the target site in response to stimuli. Various stimuli could be $\mathrm{pH}$, temperature, and magnetic field [244]. For instance, Clawson et al. synthesized LPH-NP using poly(lactic-co-glycolic acid) core and a lipid-PEG monolayer shell which could get disrupted at low acidic $\mathrm{pH}$ and release the drug. The tunable $\mathrm{pH}$ sensitivity was achieved by synthesizing lipid-(succinate)-mPEG conjugate and using different molar concentrations of this [245]. The advantage of such system included the stability of NP at neutral $\mathrm{pH}$ of blood but specific delivery at low $\mathrm{pH}$ sites in the body which includes the tumor microenvironment and deep bronchioles [246]. Similarly, LPH-NPs containing magnetic beads have been synthesized for the controlled release of drug under the external stimulus of radiofrequency (RF) magnetic field [247]. Thermosensitive nanomaterials have been recently utilized for delivering drugs at a specific target site. Temperature difference between the normal and infected tissues and temperature as the noninvasive trigger for drug release have been successfully utilized in designing nanohydrogels for the topical delivery of antiviral drugs. Examples of such polymers include poly(ethylene glycol)poly(3-caprolactone)-poly(ethylene glycol) (PCEC) and poly $n$-isopropylacrylamide/polyacrylic acid (PNIPAm/ PAA) [248]. In one study, methylcellulose modified with stearic acid was proposed as a promising thermosensitive nanocarrier for formulation of hydrogel for intravaginal delivery of tenofovir to prevent the sexual transmission of HIV [249]. The advantage of this delivery system relied on preventing the burst release of drugs and achieving controlled release over a prolonged period [250]. In a recent study, nanosized layered double hydroxides (LDHs) and poloxamer were simultaneously used to construct a hybrid thermosensitive hydrogel for the co-delivery of theaflavin, a hydrophilic drug molecule, and nifeviroc, a hydrophobic antiviral agent, for intravaginal application with the aim to block the entry of HIV by acting as a pre-exposure prophylactic microbicide [251]. Thermosensitive hydrogels have also been used for intranasal delivery of antiviral drugs like zidovudine to combat CNS viral infections [252].

\section{Multifunctional lipid-polymer hybrid nanoformulation}

It is well known that monofunctional nanoparticles can provide a single function [253]. For example, liposome is employed for the transport of drug but it does not have inherent characteristics to distinguish between healthy and unhealthy cells. Multifunctional-based LPH-NPs combine various functionalities in a single stable construct. For instance, a core particle can be linked to a specific targeting agent which has the ability to recognize the unique surface signatures of viral target cells. At the same time, the same particle can also be modified with cellular penetration moiety to enhance the 


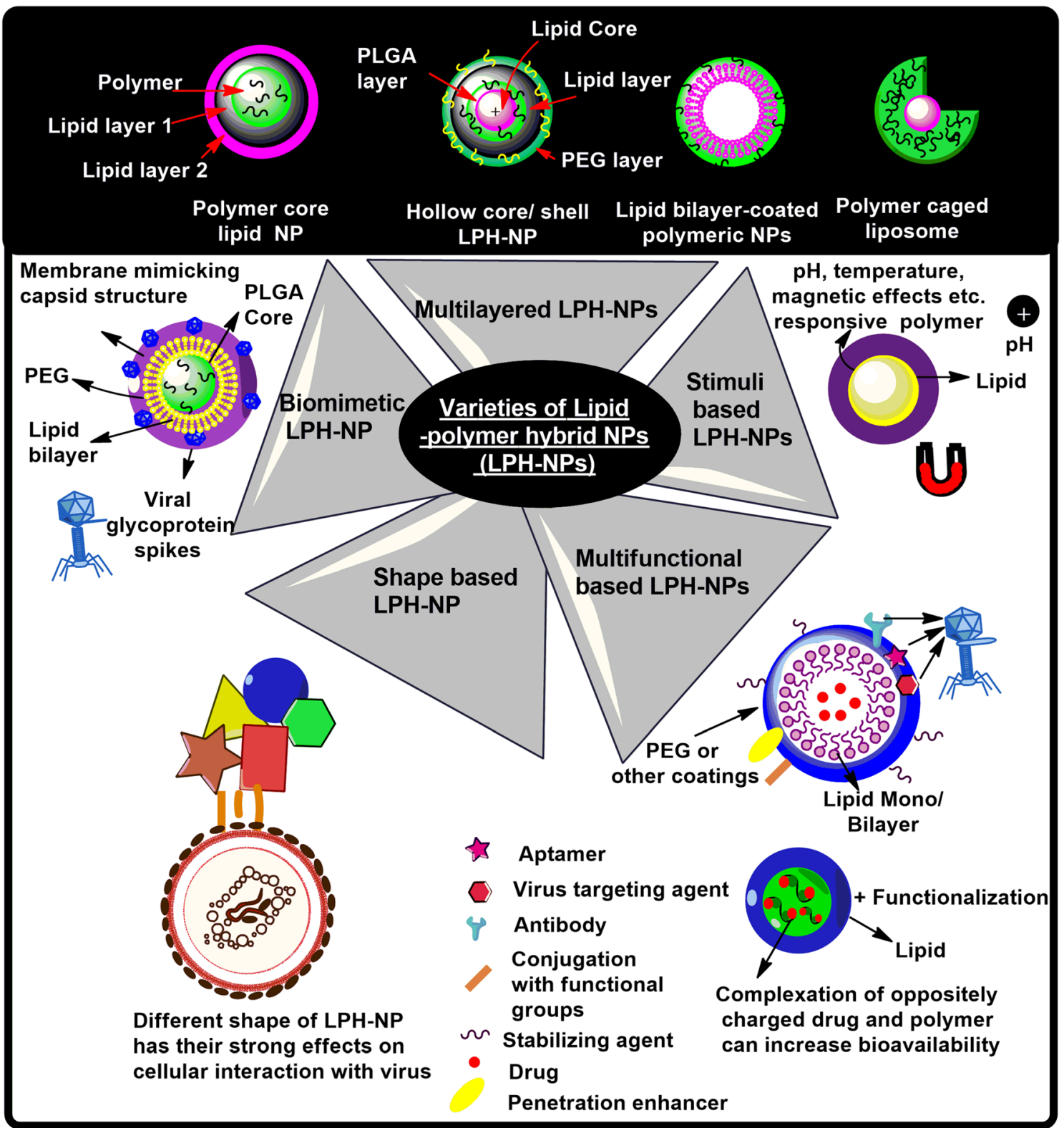

Fig. 3 Polymer-caged nanoparticles

penetration of a drug, and surface modification or coating of an additional polymer can be done to mask the undesirable interaction of the drug with a biological system, thereby enhancing the therapeutic efficacy of the drug [254]. These multifunctional nanoparticles can allow various functions like detection, diagnosis, imaging, drug delivery, cell penetration, and destruction of the virus [255]. HA nanoparticle hybrid system approach has been found promising as a multifunctional system [256]. Lee et al. have researched in this direction and proposed gold NP functionalized with HA for delivering interferon- $\alpha$ to the liver for the treatment of hepatitis $\mathrm{C}$ virus infection. HA-coated cationic lipid PLGA hybrid NP has found significant application for vaccine delivery to elicit cellular and humoral immunity [257].
Shape-based lipid-polymer hybrid nanoformulation

Viruses exhibit a variety of shapes like cylindrical helical virus, HIVs with enveloped membrane, brome mosaic virus that exhibits icosahedral symmetry, and phage T4 that has a complex shape. The existence of such diversity has instilled a need for the development of nanoparticles of different designs as drug carriers, i.e., NPs with different shapes and sizes [258]. Researchers are, therefore, exploring all possible shapes of NPs varying from spherical to nonspherical (rod, disc, star, cube, cone, hexagon, etc). Moreover, particle shape has been recognized as a new physical parameter which can exert a high impact on cells. They play an important role in cellular interaction, drug cellular uptake, and biodistribution. This can 
Table 6 Hybrid nanoformulation

\begin{tabular}{|c|c|c|c|c|c|c|}
\hline Diseases & $\begin{array}{l}\text { Antiviral } \\
\text { drug }\end{array}$ & $\begin{array}{l}\text { Type of } \\
\text { nanodelivery } \\
\text { system }\end{array}$ & Lipid and polymer which used as carrier & $\begin{array}{l}\text { Problems } \\
\text { encountered }\end{array}$ & Key findings & Ref \\
\hline HIV/AIDS & Zidovudine & $\begin{array}{l}\text { Lipid-polymer } \\
\text { hybrid } \\
\text { nanoparticles }\end{array}$ & $\begin{array}{l}\text { Stearic acid, Compritol } 888 \text { ATO, polymer } \\
\text { Gelatin }\end{array}$ & $\begin{array}{l}\text { Low aqueous } \\
\text { solubility } \\
\text { Short half-life and } \\
\text { high side effects }\end{array}$ & $\begin{array}{l}\text { High loading, } \\
\text { hemocompatibility, } \\
\text { sustained release }\end{array}$ & [232] \\
\hline HIV/AIDS & Zidovudine & $\begin{array}{l}\text { Lipid-polymer } \\
\text { hybrid } \\
\text { nanoparticles }\end{array}$ & Alginate, stearic acid, PEG & $\begin{array}{l}\text { Biocompatibility } \\
\text { problems, high } \\
\text { toxicity }\end{array}$ & $\begin{array}{l}\text { Biocompatibility, superior } \\
\text { drug-loading capacity, and } \\
\text { enhanced drug release effi- } \\
\text { cacy }\end{array}$ & [233] \\
\hline HIV/AIDS & Nevirapine & $\begin{array}{l}\text { Lipid-polymer } \\
\text { hybrid } \\
\text { nanoparticles }\end{array}$ & $\begin{array}{l}\text { PEG 400, propylene glycol, polyoxyethylene } \\
\text { polyoxypropylene (copolymer), glyceryl } \\
\text { monostearate, polyglyceryl distearate }\end{array}$ & $\begin{array}{l}\text { Decreased } \\
\text { solubility }\end{array}$ & $\begin{array}{l}\text { Increased drug delivery to } \\
\text { target sites }\end{array}$ & [233] \\
\hline HIV/AIDS & Zidovudine & $\begin{array}{l}\text { Core shell } \\
\text { nanoparticle }\end{array}$ & $\begin{array}{l}\text { Long-chain fatty acid, stearic acid, PEG, } \\
\text { dextran }\end{array}$ & $\begin{array}{l}\text { Biodegradability } \\
\text { and } \\
\text { biocompatibility }\end{array}$ & $\begin{array}{l}\text { High stability, controlled drug } \\
\text { release }\end{array}$ & [234] \\
\hline HIV/AIDS & Zidovudine & $\begin{array}{l}\text { Core shell } \\
\text { nanoparticle }\end{array}$ & PVP, stearic acid, PEG & $\begin{array}{l}\text { Short half-life } \\
\text { Low } \\
\text { bioavailability }\end{array}$ & $\begin{array}{l}\text { Decreased systemic side } \\
\text { effects, useful therapeutic } \\
\text { activity }\end{array}$ & [235] \\
\hline
\end{tabular}

therefore affect the in vivo performance of nanoparticles [259]. Recently, in the case of cancer, it was found that nonspherical NPs can provide higher therapeutic efficacy in comparison with spherical NPs [260]. Similarly, in the future, studies can be carried out in the field of virology to understand which shape of NP can increase therapeutic efficacy and also since, as a carrier, lipid polymer hybrid nanoformulation are exhibiting better results than lipid or polymer alone, they can be employed as nanocarriers for the delivery of antiviral drugs.

\section{Surface modification of nanocarriers}

Surface modification by adding charging agents or by coating is done to improve the properties of nanoformulation [261]. Coating is done to ensure that the drug remains in a dispersed state and it also helps to retain the properties of nanoparticles [262]. There are several drugs in which little surface modification in nanoparticles is done and its effectiveness is evaluated like indinavir, ritonavir, atazanavir, and efavirenz loaded in monocyte-derived macrophage-nanoparticle interactions, ampenavir loaded in Tf-conjugated quantum dots, etc [263]. A previous study listed the possible surface modifications on nanoparticles to achieve targeted drug delivery in tissues or organs [115]. A similar research has been carried out by researchers showing high improvement in drug delivery systems. In addition to this, future importance should also be given to charge present on the surface of a nanoparticle. This is because surface charge on nanocarriers, either positive, negative, or neutral, changes its behavior to a large extent [264]. Properties such as toxicity, compatibility, absorption, and elimination rate are modified by adding charging agents in lipids or polymers [265]. Hence, understanding the type of charging agents to be added can come through the study of these properties. So in this paper we would like to emphasize on the proper selection of charging agents in nanoformulation. Figure 4 provides information on which charge is preferred based on the types of nanoformulations. In 2008, Kaur et al. studied zidovudine-loaded charged liposomes or site-specific ligand mannose to evaluate its performance against the virus. They found that more concentration of drug-loaded liposomes accumulated in organs like the spleen and lymph nodes, therefore leading to more effective treatment of viral diseases [266].

\section{Nanovaccines}

Nanovaccines are engineered to modulate the immune response of the host and are among the host-directed therapies for viral infections. Numerous efforts have been made in the direction to engineer nanovaccines with the aim to overcome the disadvantages of the conventional vaccines used for the prevention of viral infections. Live-attenuated pathogen-based vaccines suffer from the limitation of reversion of pathogenic virulence and pose safety concerns, whereas inactivated pathogen-based vaccines induce weaker immune response. Subunit vaccines offer partial protection most of the time. Nanovaccines on the basis of its size, shape, functionality, and surface properties can address these issues and present enhanced and broad-spectrum immunity [267]. Other advantages include protection of the basic structure of the antigen and its prolonged presentation to immune cells. Various nanovaccines against respiratory viruses have been developed and few are under trial. They can be delivered by 


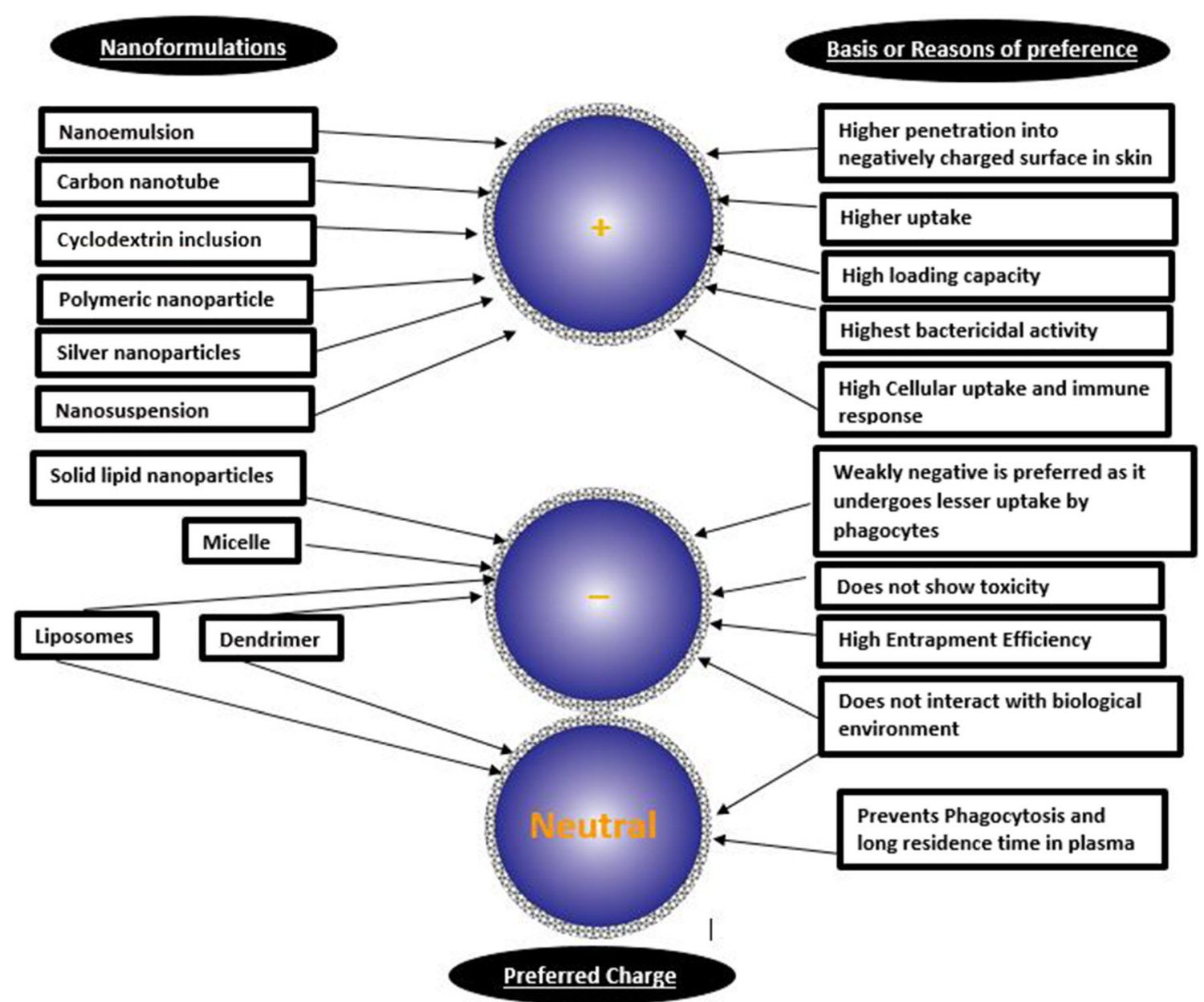

Fig. 4 Types and charges of nanoformulations

intramuscular, subcutaneous, or intranasal routes. Inclusion of antigen into nanoparticles can be brought about by encapsulation or conjugation. Some nanoparticles have their intrinsic ability to elicit immune response [268]. Table 7 enlists marketed nanovaccines.

In the last decade, a wide variety of nanoparticulate systems have been designed to induce humoral and cellular immunity against various viral infections. Various phospholipidic, polymeric, inorganic, carbon-based, metallic [269-271], and protein-based systems [272] have been explored for the development of vaccines [273-278]. In addition, the nanoparticles have been surface modified to carry antigens or epitomes to target antigen-presenting cells [279, 280]. Disulfide or thiolate-gold chemistry has been used to achieve conjugation of antigenic epitomes with nanoparticles. Advanced methods include the formation of self-assembling units to form nanoparticles surface decorated with antigens $[242,281]$.

A multifunctional nanocarrier system of a core-corona architecture, consisting of an oil core for loading immunoactive molecules, surrounded by a polymeric envelope of chitosan assembled with recombinant hepatitis B surface antigen was designed in an attempt to make a single dose vaccine formulation and to elicit a longer-lasting action of immunoprotection and avoid the use of alum as an adjuvant. Chitosan nanocapsules with positive surface charge were shown to enhance the immune response and elicited sustained effect against hepatitis B. Freeze-drying of the formulation that afforded long-term stability and recovery of its physicochemical properties on rehydration was a clear-cut advantage over alum when used as an adjuvant [282]. One more example includes the development of an effective HIV vaccine. In this design, immunogenic peptides were included into the design of polysaccharide nanoparticles consisting of chitosan and hyaluronic acid and were co-administered with polyinosinic:polycytidylic acid (poly(I:C). This system resulted in strong humoral and cellular immunogenic response [283].

\section{Nanotechnological approaches currently under investigation against SARS-CoV2}

Coronaviruses (CoVs) induced three major outbreaks of respiratory distress syndrome in the last decades, namely severe 
Table 7 Marketed Nanovaccines

\begin{tabular}{|c|c|c|c|c|}
\hline Nanovaccines & Carrier system & Composition & Areas of Use & Ref \\
\hline $\operatorname{Vaxfectin}^{\circledR}$ & Liposomes & $\begin{array}{l}\text { GAPDMORIE (a cationic lipid) and DPyPE (a } \\
\text { neutral phospholipid) in 1:1 molar ratio }\end{array}$ & $\begin{array}{l}\text { Adjuvant for plasmid-DNA } \\
\text { H5N1 influenza vaccine }\end{array}$ & {$[184]$} \\
\hline Cervarix ${ }^{\circledR}$ & $\begin{array}{l}\text { Virus like particles } \\
\text { Bivalent }\end{array}$ & $\begin{array}{l}\text { Antigenic articles from two strains of HPV } 16 \text { and } \\
18 \text { with capsid proteins L1 and L2 adsorbed onto } \\
\text { AsO4 (aluminum hydroxide and deacylated } \\
\text { monophosphoryl lipid A) as an adjuvant }\end{array}$ & Protection against two oncogenic strains of HPV & {$[185]$} \\
\hline Inflexal®V & $\begin{array}{l}\text { Virosome based } \\
\text { trivalent subunit } \\
\text { influenza vaccine }\end{array}$ & $\begin{array}{l}\text { Naturally occurring phospholipids and } \\
\text { phosphatidylcholine with viral envelope } \\
\text { glycoproteins hemagglutinin (HA) and } \\
\text { neuraminidase (NA) intercalated into it. }\end{array}$ & Retention of natural presentation of antigen & {$[186]$} \\
\hline Epaxal® & $\begin{array}{l}\text { Virosome based } \\
\text { inactivated } \\
\text { Hepatitis A virus } \\
\text { (whole virus) } \\
\text { vaccine }\end{array}$ & $\begin{array}{l}\text { Lecithin and cephalin intercalated with HA and } \\
\text { NA forming virosomes, carrying formalin } \\
\text { inactivated hepatitis A virus (HAV) adsorbed } \\
\text { onto its surface. }\end{array}$ & $\begin{array}{l}\text { Long lasting protection, advantageous in case of } \\
\text { travelers, and excellent local tolerance as } \\
\text { compared to aluminium based adjuvants, } \\
\text { compatible with coadministration of other } \\
\text { conventional vaccines }\end{array}$ & {$[187]$} \\
\hline Dermavir & $\begin{array}{l}\text { Plasmid DNA based } \\
\text { topical vaccine } \\
\text { agaawainst HIV }\end{array}$ & $\begin{array}{l}\text { Viral antigen presentation using dendritic cell } \\
\text { Contains plasmid DNA expressing all HIV } \\
\text { proteins except integrase, formulated as } \\
\text { mannosilated particle }\end{array}$ & $\begin{array}{l}\text { Specific targeting to T antigen presenting cells } \\
\text { Protection of DNA from intracellular } \\
\text { degradation Under clinical development }\end{array}$ & \\
\hline
\end{tabular}

acute respiratory syndrome (SARS) in 2003 with the epicenter in Guangdong, China; Middle East respiratory syndrome (MERS) in 2012 in Saudi Arabia; and novel coronavirus disease (COVID-19), in Wuhan Province, China, in late 2019 [284]. This virus was an unknown pathogen until January 10, 2020, when next-generation sequencing identified it as an RNA virus with genomic sequence similar to SARS-CoV of 2003 and was named as SARS-CoV2. It is a singlestranded positive sense enveloped RNA virus, approximately of $30 \mathrm{~kb}$ in length, the longest of the known RNA viruses. It is said to be zoonotic in origin, bats being the large reservoirs of this virus [285]. The viral genome consists of ORF1a and ORF1b which produces two polyproteins, pp1a (450$500 \mathrm{kDa})$ and pp1ab (750-810 kDa) [286]. This polypeptide is proteolytically processed into structural and nonstructural proteins which are important for virus survival and multiplication. This proteolytic cleavage is mainly mediated by the main protease $\left(\mathrm{M}^{\text {pro }}\right)$ also known as 3-chymotrypsin-like protease (3CL ${ }^{\text {pro }}$ ) [287]. Structural proteins include spike, envelope, membrane, nucleocapsid, and other accessory protein. The 6 nonstructural proteins play an important role in viral replication and infectivity. The spike protein is known to be essential for viral entry [288]. It is cleaved by enzymes like transmembrane protease serin 2 , furin, etc into $S_{1}$ and $S_{2} . S_{1}$ binds to angiotensin-converting enzyme-2 (ACE2) receptors expressed on the host cell and $\mathrm{S}_{2}$ facilitates membrane fusion. Under low $\mathrm{pH}$, uncoating of the virus occurs. Genomic viral RNA undergoes translation to form polyproteins (ppla/pp1ab) which then undergoes proteolysis to give nsp 3,4,6 [which forms double membrane vesicles (DMV)], RdRp, and Hel (which is transferred inside DMV) and undergoes translation. These proteins are moved into the endoplasmic reticulum-Golgi intermediate compartment (ERGIC) where the $\mathrm{N}$ protein enclosed viral genomes get attached, forming mature virions. This initiates the process of assembly of viruses and is followed by the release of viruses via exocytosis [289, 290] (as shown in Fig. 5).

The latest development in viral diseases was the advent of COVID-19, which was so named as it started in late 2019. The symptoms of this disease included fever, cough, shortness of breath, and pneumonia, ranging from mild to severe degree, with a higher transmission rate than SARS-CoV. The severe cases demonstrated respiratory, gastrointestinal, hepatic, and neurological complications that can lead to death. The humanto-human transmission of COVID-19 is reported to occur by respiratory droplets or direct contact with the patients [284].

To date, no precise antiviral cure is available for COVID19. Drug repurposing has identified remdesivir, favipiravir (RNA polymerase inhibitors), lopinavir/ritonavir combination along with interferon- $\beta$, and hydroxychloroquine as promising candidates for the treatment of this disease; however, these drugs are said to be associated with serious side effects. Certain interleukin-6 inhibitors are in clinical trials for their immunomodulatory effect in COVID-19 [291]. Zhou et al. in their study attempted to minimize the time that elapses before results from preclinical trials can be converted into desirable clinical outcomes by making quick identification of repurposable drugs possible. They looked at potential drug combinations through the lens of a medicine platform based on systems pharmacology to target 2019-nCoV/SARS-CoV2 and made it possible to quantify the interrelationship between the $\mathrm{HCoV}$-host interactome and drug targets [29].

In the fight against this devastating pandemic, nanotechnological tools have been adopted by several companies and academic institutions. These efforts have laid groundwork in the areas of rapid diagnosis, prevention, and treatment. In light 


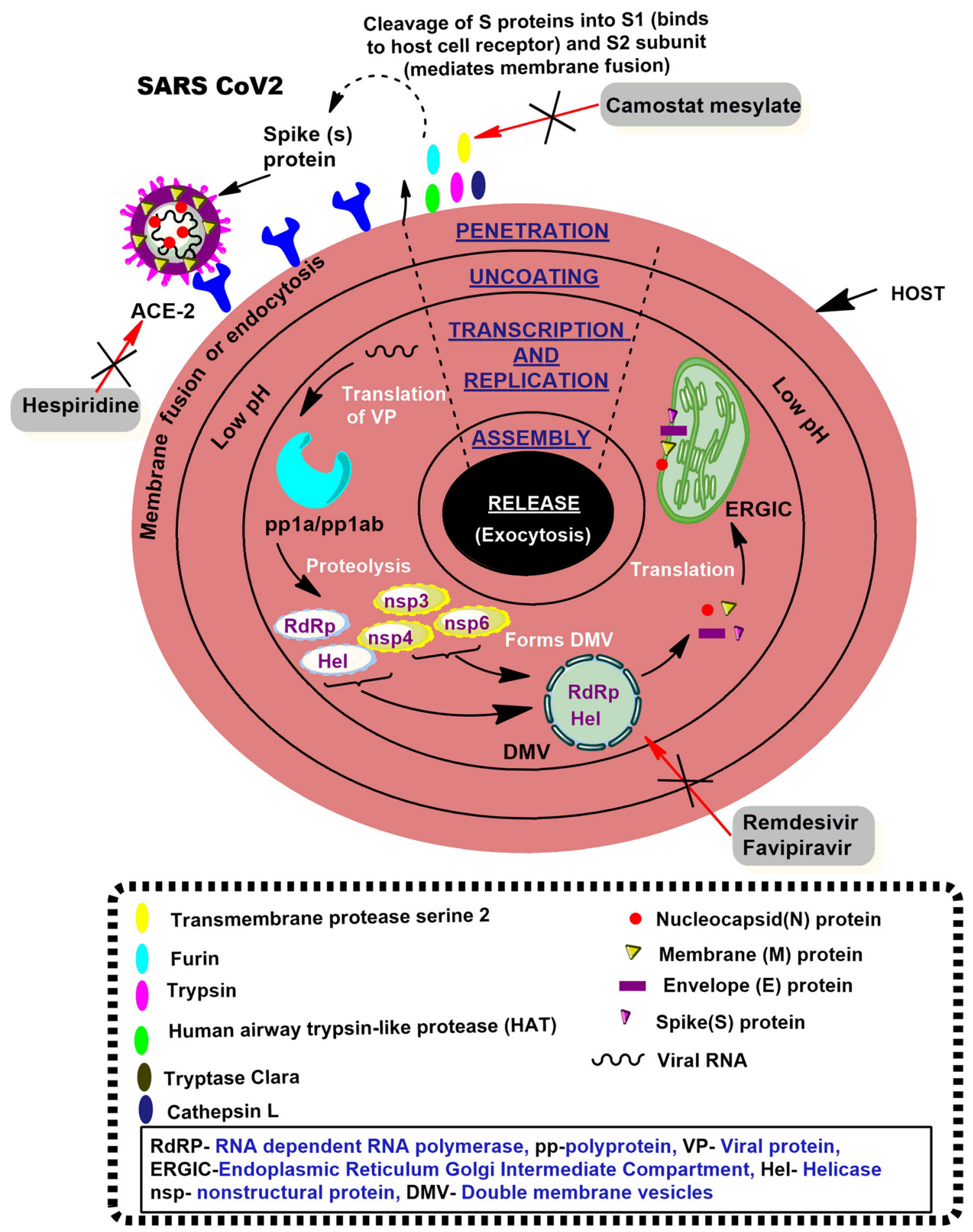

Fig. 5 Schematic representation of life cycle of novel corona virus in the host cell

of this, we present here a compilation of various efforts based on nanotechnology, going on around the globe to fight against this pandemic. We wish to state that these are not research papers; however, this compilation will help in the emergence of newer ideas and innovations.

According to the statistical analysis conducted by StatNano, there is a total of 9217 patents filed at different patent offices with respect to coronaviruses till February 13,
$2020 ; 5.2 \%$ of these are based on nanotechnology. The majority of these patents are on diagnostic technology followed by RNAi therapeutics, vaccines, and nanomaterial-based filters [292]. The following section briefs about various such approaches which are at different stages of development.

Dr. Patrick Couvreur at the Institute Galien Paris-Sud, in France, applied a multidrug nanoparticle approach to fight against the cytokine storm observed in the case of 
hyperinflammatory state of COVID-19. He encapsulated adenosine and squalene, a naturally occurring antiinflammatory compound and fat, respectively, produced in our body, in a nanoparticulate system consisting of alpha tocopherol (vitamin E envelope). The formulation was tested in mice in a state of hyperinflammation and suffering from cytokine storm to mimic the condition of COVID-19. A significant decrease in TNF- $\alpha$ along with an increase in antiinflammatory cytokine interleukin-10 was observed [293].

Arcturus Therapeutics, a company leading into RNA therapeutics based in San Diego, and Duke-NUS Medical School, a research-intensive medical school at Singapore, have collaborated their efforts to develop an mRNA-based vaccine against COVID-19. They propose to use a LUNAR platform to develop lipid-based nanoparticles to encapsulate the mRNA to trigger rapid and prolonged antigen expression within host cells resulting in protective immunity against infectious pathogens. LUNAR is known to be composed of four lipid components: a lipid proprietary to Arcturus Therapeutics, consisting of a $\mathrm{pH}$-sensitive ionizable amino group and a biodegradable lipid backbone containing an ester linkage, cholesterol, a phospholipid 1,2-distearoyl-snglycero-3-phosphocholine (DSPC), and a pegylated lipid. The amino groups remain unionized at physiological $\mathrm{pH}$, preventing toxicity due to the otherwise used cationic lipid for RNA delivery. It gets positively ionized at acidic endosomal $\mathrm{pH}$ enabling its binding to anionic lipids inside endosomes and disrupting its membrane to release the therapeutic RNA. The presence of ester linkage also makes it susceptible to cleavage by esterases, so as to produce hydrophilic products successive to cellular delivery, which can be rapidly metabolized, leading to reduced toxicity [294]. Another company Alnylam Pharmaceuticals Inc., leading in lung delivery technology, in collaboration with Vir Biotechnology Inc (both US based) is planning lipid nanoparticle-based delivery of functionalized siRNA for therapeutics against COVID-19. They propose to use SNALP as a technology platform which uses ionizable lipids, shielding lipids, cholesterol, and endogenous or exogenous targeting ligands for the delivery of nucleic acid [295, 296].

Scientists at the University of Waterloo, Canada, are designing nanotechnology-based vaccine that can be delivered through the intranasal route. They propose to deliver therapeutic DNA to target tissues through nasal spray to produce SARS-CoV2 antigenic proteins (virus-like particles) which are harmless but produce an immunogenic response against the virus [297].

Chinese researchers recently announced their success in developing a special nanomaterial (nanozyme) that can absorb and deactivate this deadly virus with the efficiency of 96.5 to $99.9 \%$ [298].

Novavax, a US-based biotechnology company, has developed a vaccine candidate using its proprietary recombinant protein nanoparticle technology platform to generate antigens derived from the coronavirus spike (S) protein. Novavax expects to utilize its proprietary Matrix-M ${ }^{\mathrm{TM}}$ adjuvant with its COVID-19 vaccine candidate to enhance immune responses [299].

Forest business, nanoSeptic, is developing a mineral nanocrystal-based technique to create a coating material which gets activated by any visible light to cause a strong oxidation reaction to completely breakdown any organic material including the virus. Similarly, a nanotech surface company in Italy has used titanium dioxide and silver ion-based nanoformulations to spray over buildings and surfaces to sanitize them. They claim that with this, the surfaces remain selfsterilized for years [300].

The Iranian government is supporting a manufacturing plant producing 4 million N95 masks per day based on nanofiber technology. They propose that nanofibers produced by electrospinning as perfect filter materials for manufacturing N95 masks. The Czech nanofiber technology firm Respilon Group has incorporated copper oxide into nanofibers to be used for producing mask that has the capability of trapping and destroying the virus. The Advanced Institute of Science and Technology (KAIST), Korea, developed nanofiber-based nanofilters using an insulation block electrospinning process which maintains its filtering efficiency even after 20 washes with ethanol. The orthogonal and unidirectional alignment of nanofibers is claimed to minimize the air pressure toward the filter and maximize filtration efficiency [301].

The World Nano Foundation (WNF) has created a secondgeneration rapid COVID-19 IgM/IgG antibody assay kit using gold nanoparticles into a testing strip. Also, an MIT spin out startup company has developed strips based on gold nanoparticles which could give the color reaction within $20 \mathrm{~min}$ of the start of the test. The strip is coated with antibodies that bind to the specific SARS-CoV2 viral protein and the second antibody is attached to gold nanoparticles. The patient's sample is placed on the strip, and if it has viral antigen which binds to both these antibodies, a colored spot appears on the strip. Sona Nanotech Inc., a Canada-based company, is developing a nanorod-based lateral flow test to screen the patient for the $\mathrm{nCoV}$ virus, which is expected to produce results within 5-15 $\mathrm{min}$ [302].

St. Olavs Hospital in Trondheim used iron oxide nanoparticles coated with silica to extract RNA from a patient's sample in an attempt to fight the COVID-19 outbreak [303].

PreLynx in their portals have used vapors of a nanopolymer-based sanitizer which gets sprayed on individuals entering through this portal along with scanning of body temperature [304].

\section{Nanoherbal formulations}

Herbal drugs and phytoconstituents are considered to be safe and efficacious in comparison with allopathic medicines. 
Globally, the use of natural medicines is increasing. Principles of nanoscience and technology have been applied to these naturally occurring drugs for the purpose of increasing their bioavailability and achieving targeted delivery [305]. Table 8 gives a compilation of nanotechnology based herbal formulation for antiviral therapy.

\section{Overcoming barriers and economization}

Despite huge efforts and funds directed toward the development of nanotechnology-based formulations for various indications for the past three decades, there are only about twenty such FDA-approved products available in the market. The majority of these formulations are for cancer and neurological disorders, with liposomes and polymeric nanoparticles being largely used for drug delivery. However, the recent trend in investigational drugs is moving toward micellar systems, nanocrystals, dendrimers, and multicomponent targeted delivery systems and the therapeutic areas addressed are bacterial, fungal, and viral infections [306]. The next decade will witness the rise of nanotechnology platforms for the treatment of microbial infections including viral.

\section{Nanotoxicity as a major limitation}

With the rapid advancement of nanoscience in the healthcare sector, its adverse effects and toxicities are parallelly assessed by many scientists. On the virtue of the same reasons that lead to its increased potency, i.e., small size, larger surface area, specific shapes, and surface charges, their interaction at nonspecific target sites also increases [307]. The major mechanism responsible for the toxicity of nanomaterials is considered to be enhanced generation of oxidative stress and inflammatory mediators in various tissues which damage the biological molecules of the cell, namely proteins, lipids, and DNA [308]. Some of the most perfused organs in the body include the liver, lungs, spleen, kidney, and heart. On account of this, they receive a maximum amount of any material that is absorbed or injected. The liver is the major site where accumulation of free radicals takes place. Hence, nanomaterials may cause hepatotoxicity, nephrotoxicity, cardiotoxicity, immunotoxicity, and genotoxicity [309]. Gold nanoparticles are shown to undergo cyanidation and oxidation in the body generating toxic products. They get heavily absorbed in the kidneys and are known to cause nephrotoxicity [310]. Similarly, various in vitro and in vivo studies have

Table 8 Nano-herbal formulations for antiviral effect

\begin{tabular}{|c|c|c|c|c|}
\hline Herb or Botanical & Nanoparticle Type & Disease & Advantages & Ref \\
\hline Hypocrellins & $\begin{array}{l}\text { A C9 monounsaturated model } \\
\text { phospholipid } \\
\text { Liposomes }\end{array}$ & HSV 1 & Increased hydophilicity and stability & [188] \\
\hline Marsupium & Phospholipid Liposomes & Viral infections & Increase in bioavailability & [189] \\
\hline Oxymatrine & Phospholipid Liposomes & Viral infections & Increase in bioavailabiliy & [190] \\
\hline $\begin{array}{l}\text { Catechins (Active constituents - } \\
(+) \text {-catechin, (-)-epicatechin }\end{array}$ & Chitosan nanoparticles & Viral infections & Increased stability of catechins & [191] \\
\hline Harungana madagascariensis & $\begin{array}{l}\text { poly(D,L-lactide-co-glycolide) } \\
\text { (PLG) nanoparticles }\end{array}$ & Viral infections & Increase in bioavailabiliy & [192] \\
\hline Quercetin & $\begin{array}{l}\text { Eudragit }{ }^{\circ} \text { E \& poly vinyl alcohol } \\
\text { nanoparticles }\end{array}$ & $\begin{array}{l}\text { Viral infections } \\
\text { like } \\
\text { DENV, } \\
\text { Influenza }\end{array}$ & Improved bioavailability and stability & [193] \\
\hline Artemisia arborescens L. & $\begin{array}{l}\text { Positively charged } \\
\text { Multilamellar liposomes } \\
\text { MLVs and small unilamellar } \\
\text { SUVs Liposomes }\end{array}$ & HSV 2 , & Increase in bioavailabiliy & [194] \\
\hline Catechin & Chitosan nanoparticles & Influenza & $\begin{array}{l}\text { Improves Bioavailability and controlled drug } \\
\text { release }\end{array}$ & [191] \\
\hline Ambrosia arborescens & Silver nanoparticles & $\begin{array}{l}\text { DENV, } \\
\text { CHIKV, } \\
\text { ZIKV }\end{array}$ & Effective in low concentration & [195] \\
\hline Phyllanthus niruri & Silver nanoparticles & DENV & Cheap \& Nontoxic materials are used & [196] \\
\hline Cymbopogon citratus & Gold nanoparticles & DENV & Effective in low concentration & [197] \\
\hline Halodule uninervis & Gold nanoparticles & $\begin{array}{l}\text { DENV, } \\
\text { CHIKV, } \\
\text { ZIKV }\end{array}$ & Cheap, easy to produce \& effective treatment & [198] \\
\hline Silybum Marianum & phytoliposomes & Hepatitis C & $\begin{array}{l}\text { High bioavailability and more active in } \\
\text { pharmacological activity. }\end{array}$ & [199] \\
\hline
\end{tabular}




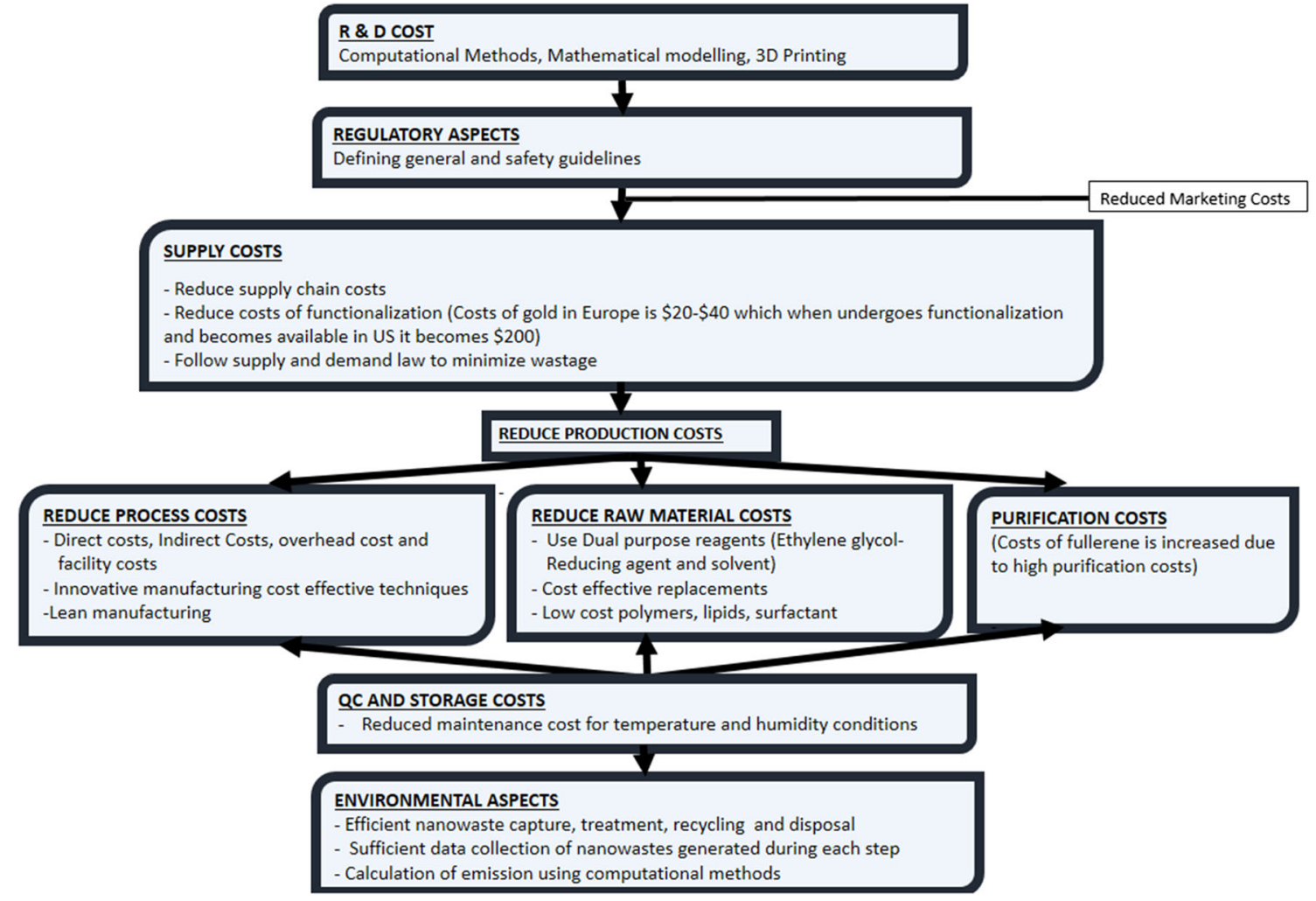

Fig. 6 Methods to overcome manufacturing and scale-up challenges

demonstrated the toxicity of silver nanoparticles (AgNP). Besides the pulmonary toxicity of inhaled $\mathrm{AgNP}$ and dermatotoxicity of topical AgNP, they are found to be harmful in sperm function as well as embryo development [311-313]. Among the metal oxide nanoparticles, $\mathrm{CuO}$ nanoparticles have shown the highest level of DNA damage and cytotoxicity in vitro [314]. $\mathrm{ZnO}$ and $\mathrm{TiO}_{2}$ nanoparticles are also known to cause potential harm to human health $[315,316]$. Numerous studies have been carried out on the toxicity of carbon-based nanomaterials. The presence of metal-based impurities and agglomeration state are considered to be major factors responsible for toxicity in carbon nanotubes (CNTs) besides size, shape, and length that have been found to be responsible for cytotoxicity. Murphy et al. have shown that long-term retention of long carbon nanotubes leads to severe inflammation and progressive fibrosis in mice [317]. It is found that $\mathrm{COOH}$-functionalized SWCNTs were more toxic than the nonfunctionalized ones [318]. In the case of MWCNT, the cationic-functionalized nanotubes are found to cause more lysosomal dysfunction as compared with - $\mathrm{COOH}$-functionalized MWCNT [319]. Numerous studies have shown multiple toxicities of graphene-based nanomaterials in cells and animals [320]. There are even reports about the clinical toxicity of polymeric nanoparticles composed of polyacrylates, where pulmonary inflammation and fibrosis were displayed [321]. The toxicity of these nanomaterials of course depends on the dose and period of exposure, and conclusion about their toxicity has to be carefully drawn based on sound testing protocols. Efforts are ongoing toward approaches to overcome these toxic effects of nanomaterials so that the potential benefits outweigh the risks.

\section{Manufacturing and scale-up challenges}

Though there is a vast amount of literature offering profound benefits of nanotechnology-based approaches to diagnose and treat viral infections, limited products have made their way to clinics. The complexity, variability, and diversity of the approaches and the absence of a detailed methodology of experimentation and characterization have made reproducibility and scale-up a big challenge [322]. The control of critical parameters during manufacturing and the effect of even minor changes on overall safety and efficacy of the product is a major challenge in the pharmaceutical development of nanomedicines [323]. FDA guidelines for the industry similar to that for 'liposomal drug products' and 'drug products, including biological products, that contain nanomaterials' are needed for the development of nanomedicines through other different approaches [323]. This may help in harmonizing efforts toward a successful product. In a similar way, testing of these products for safety and toxicity by procedures specific for nanoformulations is needed. In addition, pharmacoeconomics play a crucial role in the product's access to the market and its commercialization [323]. 
Figure 6 below enumerates the different ways by which the above drawbacks can be overcome so that nanotechnology can become cost-effective as a treatment strategy.

\section{Futuristic aspects}

Various novel delivery systems like nanotraps, nanorobots, nanobubbles, nanofibers, and nanodiamonds are paving their way in the diagnosis, prevention, and therapeutics of viral infections. These systems have broadened our vision and opened up a whole new area of research in the direction of antiviral therapeutics.

\section{Nanotraps}

Nanotraps are homogeneous hydrogel particles comprised of high affinity, charge-based, bulky aromatic baits which form the core, surrounded by a sieving shell made by polymerization reaction. They are designed to selectively trap the target virus, infectious virions, and viral proteins through hydrophobic and electrostatic interactions, while excluding high molecular weight proteins like albumin. While they are selective and versatile and provide molecular sieving, they also protect the trapped particles and proteins from degradation by proteases and are stable to various buffering temperature and storage conditions, required for downstream processing for the assay methodologies [324]. Nanotraps have found application in the diagnosis of HIV-1 infections. In one study, scientists used nanotraps having a core made up of Cibacron Blue surrounded by a sieving shell made up of polymers of $\mathrm{N}$-isopropylacrylamide, $\mathrm{N}, \mathrm{N}$-methylenebis-acrylamide, and allylamine or methacrylate with vinylsulfonic acid monomers incorporated into it. These nanotraps were found to capture and concentrate selectively HIV-1 Tat peptide, full-length Tat, Nef, p24 proteins, and cell-free virions from patients' sera as well as infected culture supernatant [325]. Acrylic acid, Acid Black 48, and pigment red are few other baits which have been used for designing nanotraps. In the past, the nanotrap concept has been used for the detection of a variety of viruses like RSV [326], Rift Valley fever virus (RVFV) [327], Venezuelan equine encephalitis virus (VEEV), human coronavirus, and influenza virus from different complex matrices like saliva, nasal fluid, and nasal aspirates [328]. Recently, nanotraps were used for high efficiency purification of intact foot-and-mouth disease virus (FMDV) for the purpose of inactivated vaccine manufacture. The purification was based on affinity between Gram-positive enhancer matrix particles (GEM) (obtained from nonliving food grade Lactococcus lactis bacteria with intact peptidoglycan envelope but without recombinant DNA or cellular components) coupled with a peptidoglycan-binding protein anchor (GEM-PA) and the FMDV-specific nanobody $(\mathrm{Nb})$. The GEM-PA-Nb nanotrap displayed easy and efficient purification of FMDV from cellular lysates [329]. Nanotrap particles have enhanced the detection sensitivity and specificity by allowing enrichment of the sample through molecular size sieving. Recently, magnetic nanotrap particles were found to concentrate and preserve the stability of VEEV and its proteins in whole human blood at elevated temperature $\left(40{ }^{\circ} \mathrm{C}\right)$ and prolonged storage conditions (72 h) [330]. Recently, magnetic nanotrap particles with different affinity baits consisting of Cibacron Blue, acrylic acid, and Reactive Red 120 have been explored to trap and enrich ZIKV, DENV, and CHIKV in human urine and saliva spiked with $1 \times 10^{6} \mathrm{PFU} / \mathrm{mL}$ of virus and found that a nanotrap system with Reactive Red 120 as the aromatic bait could recover 8-16-fold higher genomic copies of ZIKV, CHIKV, and DENV. Viral titers as low as $100 \mathrm{PFU} / \mathrm{mL}$ for ZIKV and $10 \mathrm{PFU} / \mathrm{mL}$ for CHIKV were detectable. Thus, nanotraps have revolutionized the world of viral diagnostics and hold a bright future [331].

\section{Nanorobots}

Nanorobots are multifunctional controllable machines, made up of inorganic or polymeric nanomaterials, modified with biomimetic materials performing various functions like actuation, propulsion, sensing, signaling, self-replicating, and delivering various materials with high accuracy [332]. In general, nanorobotic systems consist of a power source, sensors, actuators, onboard computers, pumps, and structural support. Additionally, it has a payload compartment to load the drug and a miniature camera to navigate through the bloodstream [333]. They are proposed to find a wide application in the development of minimally invasive diagnosis and treatment of various diseases like cancer, diabetes, and neurological and cardiovascular disorders [332]. They serve as nanosurgeons and find a direct pathway to the cell due to their nanosize and can target the drug delivery directly to the site of action. Though the technology has not been explored with respect to antiviral diagnostics and therapeutics until now, the future will definitely see research in this direction [334]. This kind of nanorobots can be comprised of a nanobiosensor established by nanoelectronics engineer experts, a nanochip, a nanotube, and a nanocontainer. A nanobiosensor can contain an antibody on its surface for targeting a particular antigen. A nanochip can receive signal from the nanobiosensor and can execute the given tasks. A nanotube can be introduced into the nucleus present in the cell using the nanochip when it receives positive signal. A nanocontainer can contain extremely concentrated DNase and RNase enzyme which can be released into the infected cell and will cut the entire genomic DNA into single nucleotides [335]. 


\section{Nanobubbles}

Nanobubbles possess an oxygen-containing core, as a result of which they are echogenic in nature and can be used for photoacoustic or ultrasonic imaging. They can be loaded with drugs and combined with ultrasound techniques and can be used for site-specific delivery. The core may consist of other gases like perfluoropentane and decafluoropentane and the shell of nanobubbles consists of lipids or polymers and a surfactant so as to provide stability, reasonable half-life, and ideal acoustic parameters to trigger the drug release from nanobubbles [336]. They find application in photodynamic therapy for supplying oxygen to the hypoxic areas for an effective anticancer treatment [337]. They display minimally invasive ultrasound-guided site-specific delivery with longer residence time and improved stability. Further, they can be surface modified for active targeting and can serve as theranostics [338]. Drug-loaded nanobubbles have also been investigated for antibiotic delivery to overcome the challenges of antibiotic resistance, as an adjuvant treatment for chronic infectious wounds. Since the versatile structure of nanobubbles allows the efficient incorporation of a variety of molecules, their application in the future can be extrapolated to the diagnosis, treatment, and prevention of viral infections with the advantage of possibility of visualizing the target area and the target drug with the help of real-time ultrasound imaging [336].

\section{Nanofibers}

Nanofibers, produced by the electrospinning technique, are potential novel drug delivery systems and have found wide applications in the delivery of antibiotics in cases of wound dressing and burns. The drug can be loaded as such or in nanoparticulate form to these nanofibers [339]. Various polymers like polyvinyl alcohol, chitosan, polycaprolactone, polyethylene oxide, polyvinyl pyrrolidone, and cellulose acetate are used for obtaining nanofibers. Core-sheath designs are used for overcoming the problem of initial burst release. They possess unique properties like large surface area and porosity with small pore size and high mechanical strength and capability to get surface modified. In one study, nanofibers prepared from soy proteins were used against the influenza virus [340]. Carson et al. achieved tunable release of various hydrophilic anti-HIV drugs like tenofovir, raltegravir, maraviroc, and azidothymidine through electrospun fibers blended with two biodegradable polyesters, polycaprolactone (PCL) and poly(lactic-co-glycolic) acid (PLGA). The ratio of these two polymers was varied to achieve sustained release ranging from $24 \mathrm{~h}$ to 30 days [341]. In another study, an antiHIV drug loaded onto mucoadhesive HA nanofiber was developed as a topical microbicide to inhibit HIV infection, as an alternative to existing intravaginal drug delivery systems which lack appropriate vaginal retention [342].

\section{Nanodiamonds}

Nanodiamonds are one of the most promising nanocarbon materials which are safe and possess favorable properties like structural stability, biocompatibility, nontoxicity, increased loading, solubility, bioavailability, and stability of the drug along with prolonged circulation times. They have stable $\mathrm{sp}^{3}$ carbon in the core and faceted surfaces which can co-ordinate water molecules surrounding their surface and, hence, possess exceptional proficiency to solubilize the water-insoluble drugs. They are produced by high temperature-high pressure (HTHP method) or by the detonation method [343]. They have been used for the delivery of various anticancer drugs, siRNAs, hormones, vitamins, and proteins. Nanodiamonds functionalized with growth factors have been used in tissue engineering and localized bone formation. They are capable of being functionally surface modified which helps in the sitespecific delivery [344]. Conjugation of an anti-HIV-1 drug efavirenz with functionalized nanodiamonds has shown increased antiviral efficacy in infected primary human macrophages. In addition, this formulation also showed enhanced passage of the drug through the blood-brain barrier in an in vitro model which used primary human brain microvascular endothelial cells and astrocytes over a sustained period of time, a clear advantage against the free drug [345]. In another study, the researchers have proposed the use of nanodiamond sorbents for the preparation of filters to purify water from the influenza virus based on their interaction. Nanodiamonds have also been proposed for diagnostic systems in virology through various imaging techniques [346]. Pham et al. conjugated purified trimeric hemagglutinin $(\mathrm{H} 7)$ to the surface of nanodiamonds which enhanced the $\mathrm{H} 7$-specific IgG immune response [347].

\section{Mathematical modeling in the treatment of viral diseases}

Mathematical modeling is one of the most upcoming techniques and an attractive treatment strategy for viral therapeutics. The model can uncover interesting facts regarding dynamics involving the spread of viral infection and factors involved in the treatment of viral diseases [348]. Since there are hardly drugs that are able to cure viral diseases completely, the use of a mathematical model may help in the discovery of novel drugs and can also assist in designing new treatment protocols and has the ability to predict future outcomes. Further, this method offers many more advantages like it is a more economical method (reduces experimental costs and wastage), can overcome drug resistance, etc [349]. Recently, a mathematical model has been devised for the control of 
Ebola by taking into consideration the Ebola characteristics, dynamic factors, economic, and time optimization [350]. To understand the dynamics of corona transmission, mathematical models are being generated making use of ordinary differential equations, Markov chain Monte Carlo methods or the serial intervals and intrinsic growth rate to calculate the basic reproduction number, etc [351].

\section{Conclusion}

Nanotechnology has revolutionized the world by offering innovative solutions to multiple problems associated with various areas of healthcare today. The recent advances in the design and engineering of nanomedicines have offered a number of advantages over conventional methods of prevention, diagnosis, and treatment of viral infections. The superiority of nanomedicine approaches lies in presenting unique characteristics like small particle size, high area to volume ratio, flexibility to get surface modified in order to achieve desired selectivity, and biocompatibility. Additionally, these novel approaches present enormous potential in antiviral therapeutics by helping to overcome the problems of resistance to therapy, low solubility and bioavailability of drugs, burst release, and short duration of action.

Future research can be directed to achieve 'multifunctionalization' of nanomaterials in order to achieve site-specific, concurrent delivery of multiple drugs and 'multiplexing' in order to achieve treatment of broad spectrum of diseases and associated comorbidities in a heterogeneous population. Development of theranostics which can bring about accurate diagnosis along with effective treatment and real-time monitoring is becoming increasingly essential in the field of viral infections. Various technologies like nanotraps, nanodiamonds, and nanofibers have found their way in ongoing research against influenza and HIV-1 viruses and can be further extended to other viral infections. Studies to enhance immune response and usage of nanomaterials as adjuvant to antiviral vaccines have been promising in the prevention and control of viral infections.

Among the few barriers in the development of these advanced forms of nanomaterials are the complexities involved in their fabrication and characterization and their large-scale production. The concern of long-term toxicity should be given paramount importance while designing the nanomaterials. However, with rapid advancements in the field of material chemistry, biology, and technology, one can be hopeful that the rate at which the emergence of new viral infections takes place can be controlled and the overall management of viral infections can be more effective.

Author contribution statement We are responsible in total for the contents of this paper, from inception to its completion.

\section{Compliance with ethical standards}

Competing interest The authors declare that they have no competing interest.

\section{References}

1. Rajbari M, Rajbari N, Faridpur F. Morbidity and mortality due to Nipah or Nipah-like virus encephalitis in WHO South-East Asia Region Country: India 2018;2018. Available from: http://www. searo.who.int/entity/emerging_diseases/links/morbidity-andmortality-nipah-sear-2001-2018.pdf.

2. Immunisation Coalition 2019 Influenza statistics - Immunisation Coalition [Internet]. [cited 2019 Apr 12]. Available from: https:// www.immunisationcoalition.org.au/news-media/2019-influenzastatistics/

3. S C, Mishra AK, Bazroy J. Trend of morbidity and mortality of dengue in Tamil Nadu and Puducherry, South India. Int J Community Med Public Heal. 2017;5:322. Available from: http://www.ijcmph.com/index.php/ijcmph/article/view/2291.

4. CDTR-Disease, communicable report, threats. 2018;20-6. Available from: https://ecdc.europa.eu/sites/portal/files/documents/ Communicable-disease-threats-report-26-may-2018_0.pdf.

5. Lopez-Diez E, Perez S, Carballo M, Inarrea A, de la Orden A, Castro M, et al. Lifestyle factors and oncogenic papillomavirus infection in a high-risk male population. PLoS One. 2017;12: e0184492.

6. Fuller TL, Calvet G, Estevam CG, Angelo JR, Abiodun GJ, Halai UA, et al. Behavioral, climatic, and environmental risk factors for Zika and chikungunya virus infections in Rio de Janeiro, Brazil, 2015-16. PLoS One. 2017;12:1-15.

7. Reker C, Islam KM. Risk factors associated with high prevalence rates of hepatitis C infection in Egypt. Int J Infect Dis. 2014;25: 104-6. https://doi.org/10.1016/j.ijid.2014.02.003.

8. Zhu J-D, Meng W, Wang X-J, Wang H-CR. Broad-spectrum antiviral agents. Front Microbiol. 2015;6. Available from: http://www. frontiersin.org/Virology/10.3389/fmicb.2015.00517/abstract.

9. Chinchar VG. Replication of viruses. Encycl Virol [Internet]. Elsevier; 1999. p. 1471-8. Available from: https://linkinghub. elsevier.com/retrieve/pii/B0122270304002454

10. Baron S, Fons M AT. Viral pathogenesis medical microbiology. 4th edn. S, Baron.

11. Manjarrez-zavala ME, Rosete-olvera DP, Gutiérrez-gonzález LH, Ocadiz-delgado R, Cabello-gutiérrez C. Pathogenesis of viral respiratory infection 2013; p. 3-32.

12. Rouse BT, Sehrawat S. Immunity and immunopathology to viruses: what decides the outcome? Nat Rev Immunol. 2010;10:514 26. Available from: http://www.nature.com/articles/nri2802.

13. Ferhadian D, Contrant M, Printz-Schweigert A, Smyth RP, Paillart J-C, Marquet R. Structural and functional motifs in influenza virus RNAs. Front Microbiol. 2018;9. Available from: http:// journal.frontiersin.org/article/10.3389/fmicb.2018.00559/full.

14. Yan X, Wang Q, Zhang Z, Xie Y, Zhang H, Razi M, et al. Involvement of non-structural proteins (NS) in influenza A infection and viral tropism. Biochem Biophys Res Commun. Elsevier Inc.; 2012;428:62-7. Available from: https://doi.org/10.1016/j. bbrc.2012.10.006

15. Cooper NJ. Effectiveness of neuraminidase inhibitors in treatment and prevention of influenza A and B: systematic review and metaanalyses of randomised controlled trials. BMJ. 2003;326:12351235. Available from: http://www.bmj.com/cgi/doi/10.1136/bmj. 326.7401 .1235 . 
16. UYEKI TM. Influenza diagnosis and treatment in children: a review of studies on clinically useful tests and antiviral treatment for influenza. Pediatr Infect Dis J. 2003;22:164-77. Available from: https:// insights.ovid.com/crossref?an=00006454-200302000-00015.

17. Dahlke C, Kasonta R, Lunemann S, Krähling V, Zinser ME, Biedenkopf N, et al. Dose-dependent T-cell dynamics and cytokine cascade following rVSV-ZEBOV immunization. EBioMedicine. 2017.

18. Merk A, Subramaniam S. HIV-1 envelope glycoprotein structure. Curr Opin Struct Biol. 2013;23:268-76. Available from: https:// linkinghub.elsevier.com/retrieve/pii/S0959440X13000493.

19. Laskey SB, Siliciano RF. A mechanistic theory to explain the efficacy of antiretroviral therapy. Nat Rev Microbiol. 2014;12: 772-80. https://doi.org/10.1038/nrmicro3351.

20. De Clercq E. Anti-HIV drugs: 25 compounds approved within 25 years after the discovery of HIV. Int J Antimicrob Agents. 2009;33:307-20. Available from: http://linkinghub.elsevier.com/ retrieve/pii/S0924857908004846.

21. Shukla D, Spear PG. Herpesviruses and heparan sulfate: an intimate relationship in aid of viral entry. J Clin Invest. 2001;108:503-10.

22. $\mathrm{Gu} \mathrm{M}$, Rice CM. Structures of hepatitis $\mathrm{C}$ virus nonstructural proteins required for replicase assembly and function. Curr Opin Virol. Elsevier B.V.; 2013;3:129-36. Available from: https://doi. org/10.1016/j.coviro.2013.03.013

23. Sager G, Gabaglio S, Sztul E, Belov G. Role of host cell secretory machinery in zika virus life cycle. Viruses. 2018;10:559. Available from: http://www.mdpi.com/1999-4915/10/10/559

24. Qin C, Qi J, Gao GF. Structures of the zika virus envelope protein and its complex with a flavivirus broadly protective antibody. Cell Host Microbe. Elsevier Inc.; 2016;1-9. https://doi.org/10.1016/j. chom.2016.04.013

25. Reid S, Rimmer K, Thakur K. Zika virus and neurologic disease. Neurol Clin. Elsevier Inc; 2018;36:767-87. Available from: https://doi.org/10.1016/j.ncl.2018.06.003.

26. Guabiraba R, Ryffel B. Dengue virus infection: current concepts in immune mechanisms and lessons from murine models. Immunology. 2014;141:143-56. Available from: http://doi. wiley.com/10.1111/imm.12188.

27. Srivastava V. Quinacrine and berberine as antiviral agents against dengue and zika fever: in silico approach. 2018;2:2016-9.

28. Osuna-Ramos JF, Reyes-Ruiz JM, del Ángel RM. The role of host cholesterol during flavivirus infection. Front Cell Infect Microbiol. 2018;8:1-12.

29. Zhou Y, Hou Y, Shen J, Huang Y, Martin W, Cheng F. Networkbased drug repurposing for novel coronavirus 2019-nCoV/SARSCoV-2. Cell Discov. 2020;6:14. Available from: http://www. nature.com/articles/s41421-020-0153-3.

30. Oshikoya KA, Ogunleye, Lawal, Senbanjo S, Oreagba. Clinically significant interactions between antiretroviral and co-prescribed drugs for HIV-infected children: profiling and comparison of two drug databases. Ther Clin Risk Manag. 2013;215. Available from: http://www.dovepress.com/clinically-significant-interactionsbetween-antiretroviral-and-co-pres-peer-reviewed-article-TCRM.

31. Gerber JG. Using pharmacokinetics to optimize antiretroviral drug-drug interactions in the treatment of human immunodeficiency virus infection. Clin Infect Dis. 2000;30:S123-9. Available from: http://academic.oup.com/cid/article/30/Supplement_2/ S123/371450/Using-Pharmacokinetics-to-OptimizeAntiretroviral.

32. Strasfeld L, Chou S. Antiviral drug resistance: mechanisms and clinical implications. Infect Dis Clin N Am. 2010;24:413-37. Available from: https://linkinghub.elsevier.com/retrieve/pii/ S0891552010000024.

33. Singh R, Lilliard JW Jr. Nanoparticle-based targeted drug delivery. Exp Mol Pathol. 2009;86:215-23.
34. Vyas SP, Subhedar R, Jain S. Development and characterization of emulsomes for sustained and targeted delivery of an antiviral agent to liver. 2006;321-326.

35. Chaudhuri A. Diagnosis and treatment of viral encephalitis. Postgrad Med J. 2002;78:575-83. Available from: http://pmj. bmj.com/cgi/doi/10.1136/pmj.78.924.575.

36. Bule M, Khan F, Niaz K. Antivirals: past, present and future. Recent Adv Anim Virol. Singapore: Springer Singapore; 2019. p. 425-46. Available from: http://link.springer.com/10.1007/ 978-981-13-9073-9 22.

37. Adalja A, Inglesby T. Broad-spectrum antiviral agents: a crucial pandemic tool. Expert Rev Anti-Infect Ther. 2019;17:467-70. Available from: https://www.tandfonline.com/doi/full/10.1080/ 14787210.2019 .1635009 .

38. Mendes PM. Cellular nanotechnology: making biological interfaces smarter. Chem Soc Rev. 2013;42:9207. Available from: http://xlink.rsc.org/?DOI=c3cs60198f.

39. Villanueva-Flores F, Castro-Lugo A, Ramírez OT, Palomares LA. Understanding cellular interactions with nanomaterials: towards a rational design of medical nanodevices. Nanotechnology. 2020;31:132002.

40. Cojocaru F-D, Botezat D, Gardikiotis I, Uritu C-M, Dodi G, Trandafir L, et al. Nanomaterials designed for antiviral drug delivery transport across biological barriers. Pharmaceutics. 2020;12: 171. Available from: https://www.mdpi.com/1999-4923/12/2/171.

41. Joo K-I, Lei Y, Lee C-L, Lo J, Xie J, Hamm-Alvarez SF, et al. Site-specific labeling of enveloped viruses with quantum dots for single virus tracking. ACS Nano. 2008;2:1553-62. Available from: https://pubs.acs.org/doi/10.1021/nn8002136.

42. Saini R, Saini S, Sharma S. Nanotechnology: The future medicine. J Cutan Aesthet Surg. 2010;3:32-3.

43. Blecher K, Nasir A, Friedman A. The growing role of nanotechnology in combating infectious disease. Virulence. 2011;2:395401. Available from: http://www.tandfonline.com/doi/abs/10. 4161/viru.2.5.17035.

44. Puri A, Loomis K, Smith B, Lee J-H, Yavlovich A, Heldman E, et al. Lipid-based nanoparticles as pharmaceutical drug carriers: from concepts to clinic. Crit Rev Ther Drug Carrier Syst. 2009;26: 523-80. Available from: http://www.ncbi.nlm.nih.gov/pubmed/ 20402623.

45. Mukherjee S, Ray S, Thakur R. Solid lipid nanoparticles: a modern formulation approach in drug delivery system. Indian J Pharm Sci. 2009;71:349 Available from: http://www.ijpsonline.com/text. asp?2009/71/4/349/57282.

46. Nabi B, Rehman S, Baboota S, Ali J. Insights on oral drug delivery of lipid nanocarriers: a win-win solution for augmenting bioavailability of antiretroviral drugs. AAPS PharmSciTech. 2019;20:60 Available from: http://link.springer.com/10.1208/s12249-0181284-9.

47. Attama AA, Momoh MA, Builders PF. Lipid nanoparticulate drug delivery systems: a revolution in dosage form design and development. Recent Adv Nov Drug Carr Syst. InTech; 2012. Available from: http://www.intechopen.com/books/recent-advances-in-noveldrug-carrier-systems/lipid-nanoparticulate-drug-delivery-systems-arevolution-in-dosage-form-design-and-development.

48. Li T, Cipolla D, Rades T, Boyd BJ. Drug nanocrystallisation within liposomes. J Control Release. 2018;288:96-110 Available from: https://linkinghub.elsevier.com/retrieve/pii/ S0168365918305182.

49. He H, Lu Y, Qi J, Zhu Q, Chen Z, Wu W. Adapting liposomes for oral drug delivery. Acta Pharm Sin B. 2018; Available from: https://linkinghub.elsevier.com/retrieve/pii/S2211383517307311.

50. Huang Z, Li X, Zhang T, Song Y, She Z, Li J, et al. Progress involving new techniques for liposome preparation. Asian J Pharm Sci. 2014;9:176-82 Available from: https://linkinghub. elsevier.com/retrieve/pii/S1818087614000336. 
51. Mishra V, Bansal K, Verma A, Yadav N, Thakur S, Sudhakar K, et al. Solid lipid nanoparticles: emerging colloidal nano drug delivery systems. Pharmaceutics. 2018;10:191 Available from: http://www.mdpi.com/1999-4923/10/4/191.

52. Makwana V, Jain R, Patel K, Nivsarkar M, Joshi A. Solid lipid nanoparticles (SLN) of Efavirenz as lymph targeting drug delivery system: elucidation of mechanism of uptake using chylomicron flow blocking approach. Int J Pharm. Elsevier B.V.; 2015;495: 439-46. Available from: https://doi.org/10.1016/j.ijpharm.2015. 09.014 .

53. Guo D, Zhou T, Araínga M, Palandri D, Gautam N, Bronich T, et al. Creation of a long-acting nanoformulated 29,39-dideoxy-39thiacytidine. J Acquir Immune Defic Syndr. Springer US. 2017;74:e75-83. https://doi.org/10.1038/s41467-018-02885-x.

54. Müller RH, Alexiev U, Sinambela P, Keck CM. Nanostructured lipid carriers (NLC): the second generation of solid lipid nanoparticles. Percutaneous penetration enhancers chemical methods in penetration enhancement.. Dragicevic N, Maibach HI, editors. Berlin: Springer; 2016. Available from: http://link.springer.com/ 10.1007/978-3-662-47862-2

55. Kuo Y-C, Chung J-F. Physicochemical properties of nevirapineloaded solid lipid nanoparticles and nanostructured lipid carriers. Colloids Surfaces B Biointerfaces. 2011;83:299-306 Available from: https://linkinghub.elsevier.com/retrieve/pii/ S0927776510006685.

56. Kanwar R, Rathee J, Salunke DB, Mehta SK. Green nanotechnology-driven drug delivery assemblies. ACS Omega. 2019;4:8804-15 Available from: https://pubs.acs.org/doi/10. 1021/acsomega.9b00304.

57. Kumar Gupta P, Bhandari N, Shah NH, Khanchandani V, Keerthana R, Nagarajan V et al. An update on nanoemulsions using nanosized liquid in liquid colloidal systems. Nanoemulsions - Prop Fabr Appl. IntechOpen; 2019. Available from: https://www. intechopen.com/books/nanoemulsions-properties-fabrications-andapplications/an-update-on-nanoemulsions-using-nanosized-liquidin-liquid-colloidal-systems.

58. Hobson JJ, Edwards S, Slater RA, Martin P, Owen A, Rannard SP. Branched copolymer-stabilised nanoemulsions as new candidate oral drug delivery systems. RSC Adv. 2018;8:12984-91 Available from: http://xlink.rsc.org/?DOI=C8RA01944D.

59. Sutradhar KB, Amin ML. Nanoemulsions: increasing possibilities in drug delivery. Eur J Nanomed. 2013;5 Available from: https:// www.degruyter.com/view/j/ejnm.2013.5.issue-2/ejnm-20130001/ejnm-2013-0001.xml.

60. Manyarara TE, Khoza S, Dube A, Maponga CC. Formulation and characterization of a paediatric nanoemulsion dosage form with modified oral drug delivery system for improved dissolution rate of nevirapine. MRS Adv. 2018;3:2203-19 Available from: https:// www.cambridge.org/core/product/identifier/ S2059852118003201/type/journal article.

61. Vyas TK, Shahiwala A, Amiji MM. Improved oral bioavailability and brain transport of saquinavir upon administration in novel nanoemulsion formulations. Int J Pharm. 2008;347:93-101.

62. Prabhakar K, Afzal SM, Surender G, Kishan V. Tween 80 containing lipid nanoemulsions for delivery of indinavir to brain. Acta Pharm Sin B. 2013;3:345-53 Available from: https:/linkinghub. elsevier.com/retrieve/pii/S2211383513000774.

63. M US, Lobo FJR, Uppuluri KB. Self nano emulsifying drug delivery systems for oral delivery of hydrophobic drugs. Biomed Pharmacol J. 2013;6:355-62 Available from: http://www. biomedpharmajournal.org/absdoic.php?snoid $=425$.

64. Selvam RP, Kulkarni PK. Design and evaluation of self nanoemulsifying systems for poorly water soluble HIV drug. J PharmaSciTech. 2014;4:23-8 Available from: http://www. pharmascitech.in/admin/php/uploads/84_pdf.pdf.
65. O'Keefe EP. siRNAs and shRNAs: tools for protein knockdown by gene silencing. Mater Methods. 2013;3 Available from: http:// www.labome.com/method/siRNAs-and-shRNAs-Tools-forProtein-Knockdown-by-Gene-Silencing.html.

66. Cullis PR, Hope MJ. Lipid nanoparticle systems for enabling gene therapies. Mol Ther. 2017;25:1467-75 Available from: https:// linkinghub.elsevier.com/retrieve/pii/S1525001617301119.

67. Thi EP, Lee ACH, Geisbert JB, Ursic-Bedoya R, Agans KN, Robbins M, et al. Rescue of non-human primates from advanced Sudan ebolavirus infection with lipid encapsulated siRNA. Nat Microbiol. 2016;1:16142 Available from: http://www.nature. com/articles/nmicrobiol2016142.

68. Leung AKK, Tam YYC, Cullis PR. Lipid nanoparticles for short interfering RNA delivery. Adv Genet Elsevier; 2014. https://doi. org/10.1016/B978-0-12-800148-6.00004-3.

69. Nayak D, Boxi A, Ashe S, Thathapudi NC, Nayak B. Stavudine loaded gelatin liposomes for HIV therapy: preparation, characterization and in vitro cytotoxic evaluation. Mater Sci Eng C. Elsevier B.V. 2017;73:406-16. https://doi.org/10.1016/j.msec.2016.12.073.

70. Jain S, Mistry MA, Swarnakar NK. Enhanced dermal delivery of acyclovir using solid lipid nanoparticles. Drug Deliv Transl Res. 2011;1:395-406 Available from: http://link.springer.com/10. 1007/s13346-011-0036-0.

71. Seyfoddin A, Al-Kassas R. Development of solid lipid nanoparticles and nanostructured lipid carriers for improving ocular delivery of acyclovir. Drug Dev Ind Pharm. 2013;39:508-19 Available from: http://www.tandfonline.com/doi/full/10.3109/03639045. 2012.665460.

72. McDonald TO, Giardiello M, Martin P, Siccardi M, Liptrott NJ, Smith D, et al. Antiretroviral solid drug nanoparticles with enhanced oral bioavailability: production, characterization, and in vitro-in vivo correlation. Adv Healthc Mater. 2014;3:400-11 Available from: http://doi.wiley.com/10.1002/adhm.201300280.

73. Ravi PR, Vats R. Comparative pharmacokinetic evaluation of lopinavir and lopinavir-loaded solid lipid nanoparticles in hepatic impaired rat model. J Pharm Pharmacol. 2017;69:823-33.

74. Khosa A, Reddi S, Saha RN. Nanostructured lipid carriers for sitespecific drug delivery. Biomed Pharmacother. 2018;103:598-613 Available from: https://linkinghub.elsevier.com/retrieve/pii/ S0753332218313222.

75. FENG M. Liver targeting and anti-HBV activity of reconstituted HDL-acyclovir palmitate complex. Eur J Pharm Biopharm. 2008;68:688-93 Available from: http://linkinghub.elsevier.com/ retrieve/pii/S0939641107002524.

76. Kaushik S. Polymeric and ceramic nanoparticles: possible role in biomedical applications. Handb Polym Ceram Nanotechnol. Cham: Springer International Publishing; 2020. p. 1-17. Available from: http:/link.springer.com/10.1007/978-3-030-10614-0 39-1.

77. Chiappetta DA, Hocht C, Taira C, Sosnik A. Efavirenz-loaded polymeric micelles for pediatric anti-HIV pharmacotherapy with significantly higher oral bioavailability. Nanomedicine. 2010;5: 11-23 Available from: https://www.futuremedicine.com/doi/10. 2217/nnm.09.90

78. Sawdon AJ, Peng C-A. Polymeric micelles for acyclovir drug delivery. Colloids Surfaces B Biointerfaces. 2014;122:738-45 Available from: https://linkinghub.elsevier.com/retrieve/pii/ S0927776514004330.

79. Li Q, Du Y-Z, Yuan H, Zhang X-G, Miao J, Cui F-D, et al. Synthesis of lamivudine stearate and antiviral activity of stearic acid-g-chitosan oligosaccharide polymeric micelles delivery system. Eur J Pharm Sci. 2010;41:498-507 Available from: https:// linkinghub.elsevier.com/retrieve/pii/S0928098710003015.

80. Varshosaz J, Taymouri S, Jafari E, Jahanian-Najafabadi A, Taheri A. Formulation and characterization of cellulose acetate butyrate nanoparticles loaded with nevirapine for HIV treatment. J Drug 
Deliv Sci Technol. 2018;48:9-20 Available from: https:// linkinghub.elsevier.com/retrieve/pii/S1773224718306178.

81. Martins C, Araújo F, Gomes MJ, Fernandes C, Nunes R, Li W, et al. Using microfluidic platforms to develop CNS-targeted polymeric nanoparticles for HIV therapy. Eur J Pharm Biopharm. Elsevier; 2018;0-1. https://doi.org/10.1016/j.ejpb.2018.01.014

82. Ogunwuyi O, Kumari N, Smith KA, Bolshakov O, Adesina S, Gugssa A, et al. Antiretroviral drugs-loaded nanoparticles fabricated by dispersion polymerization with potential for HIV/AIDS treatment. Infect Dis Res Treat. 2016;9:IDRT.S38108 Available from: http://journals.sagepub.com/doi/10.4137/IDRT.S38108.

83. Kuo Y-C, Chung C-Y. Transcytosis of CRM197-grafted polybutylcyanoacrylate nanoparticles for delivering zidovudine across human brain-microvascular endothelial cells. Colloids Surfaces B Biointerfaces. 2012;91:242-9 Available from: https:// linkinghub.elsevier.com/retrieve/pii/S0927776511006527.

84. Cheung R, Ng T, Wong J, Chan W. Chitosan: an update on potential biomedical and pharmaceutical applications. Mar Drugs. 2015;13:5156-86 Available from: http://www.mdpi.com/16603397/13/8/5156.

85. Panagopoulos P, Tsiodras S, Antoniadou A, Katsarolis I, Papadopoulos A, Poulakou G, et al. Efficacy and safety of an anti-retroviral combination regimen including either efavirenz or lopinavir-ritonavir with a backbone of two nucleoside reverse transcriptase inhibitors. Clin Microbiol Infect. 2006;12:486-9 Available from: https://linkinghub.elsevier.com/retrieve/pii/ S1198743X14620164.

86. Dhoke DM, Basaiyye SS, Khedekar PB. Development and characterization of L-HSA conjugated PLGA nanoparticle for hepatocyte targeted delivery of antiviral drug. J Drug Deliv Sci Technol. 2018;47:77-94 Available from: https://linkinghub.elsevier.com/ retrieve/pii/S1773224718303496.

87. Gong Y, Chowdhury P, Midde NM, Rahman MA, Yallapu MM, Kumar S. Novel elvitegravir nanoformulation approach to suppress the viral load in HIV-infected macrophages. Biochem Biophys Reports. Elsevier B.V. 2017;12:214-9. https://doi.org/ 10.1016/j.bbrep.2017.10.005.

88. Alka S. Development and evaluation of cyclodextrin based nanosponges for bioavailability enhancement of poorly bioavailable drug. World Jornal of Pharmacy and Pharmaceutical Sciences. 2017;6:805-36.

89. Hassan H, Adam SK, Othman F, Shamsuddin AF, Basir R. Antiviral nanodelivery systems: current trends in acyclovir administration. J Nanomater. 2016;2016:1-8 Available from: https:// www.hindawi.com/journals/jnm/2016/4591634/.

90. Patel A, Shelat P, Lalwani A. Development and optimization of solid self-nanoemulsifying drug delivery system (S-SNEDDS) using Scheffe's design for improvement of oral bioavailability of nelfinavir mesylate. Drug Deliv Transl Res. 2014;4:171-86 Available from: http://link.springer.com/10.1007/s13346-0140191-1.

91. Sathigari S, Chadha G, Lee Y-HP, Wright N, Parsons DL, Rangari VK, et al. Physicochemical characterization of efavirenzcyclodextrin inclusion complexes. AAPS PharmSciTech. 2009;10:81-7 Available from: http://www.springerlink.com/ index/10.1208/s12249-008-9180-3.

92. Lai SK, Wang Y-Y, Hanes J. Mucus-penetrating nanoparticles for drug and gene delivery to mucosal tissues. Adv Drug Deliv Rev. 2009;61:158-71 Available from: http://linkinghub.elsevier.com/ retrieve/pii/S0169409X08002652.

93. Sun B, Yeo Y. Nanocrystals for the parenteral delivery of poorly water-soluble drugs. Curr Opin Solid State Mater Sci. 2012;16: 295-301 Available from: http://linkinghub.elsevier.com/retrieve/ pii/S135902861200054X.
94. Kaur G, Aggarwal G, Harikumar SL. Nanosponge: new colloidal drug delivery system for topical delivery. Indo Global J Pharm Sci. 2015;5:53-7.

95. Tejashri G, Amrita B, Darshana J. Cyclodextrin based nanosponges for pharmaceutical use: a review. Acta Pharm. 2013;63:335-58.

96. Pothen LA, Thomas S. Encapsulation of zidovudine in PF-68 coated alginate conjugate nanoparticles for anti-HIV drug delivery. Int J Biol Macromol. Elsevier B.V.; 2017. https://doi.org/10. 1016/j.ijbiomac.2017.09.078

97. Ratemi E. pH-responsive polymers for drug delivery applications. Stimuli Responsive Polym. Nanocarriers Drug Deliv. Appl. Vol. 1 Types Triggers. Elsevier Ltd.; 2018. https://doi.org/10.1016/ B978-0-08-101997-9.00005-9

98. Bhaskar VV, Middha A, Srivastava P, Rajagopal S. Liquid chromatography/tandem mass spectrometry method for quantitative estimation of solutol HS15 and its applications. J Pharm Anal. 2015;5:120-9 Available from: https://linkinghub.elsevier.com/ retrieve/pii/S2095177914000835.

99. Kumar S, Dilbaghi N, Saharan R, Bhanjana G. Nanotechnology as emerging tool for enhancing solubility of poorly water-soluble drugs. Bionanoscience. 2012;2:227-50.

100. Cabral H, Miyata K, Osada K, Kataoka K. Block copolymer micelles in nanomedicine applications. Chem Rev. 2018;118:6844 92 Available from: https://pubs.acs.org/doi/10.1021/acs.chemrev. 8 b00199.

101. Miyata K, Christie RJ, Kataoka K. Polymeric micelles for nanoscale drug delivery. React Funct Polym. 2011;71:227-34 Available from: https://linkinghub.elsevier.com/retrieve/pii/ S1381514810001835.

102. Kataoka K, Harada A, Nagasaki Y. Block copolymer micelles for drug delivery: design, characterization and biological significance. Adv Drug Deliv Rev. 2001;47:113-31 Available from: https:// linkinghub.elsevier.com/retrieve/pii/S0169409X00001241.

103. Mandal A, Bisht R, Rupenthal ID, Mitra AK. Polymeric micelles for ocular drug delivery: from structural frameworks to recent preclinical studies. J Control Release. 2017;248:96-116 Available from: https://linkinghub.elsevier.com/retrieve/pii/ S0168365917300172.

104. Gill KK, Kaddoumi A, Nazzal S. PEG-lipid micelles as drug carriers: physiochemical attributes, formulation principles and biological implication. J Drug Target. 2015;23:222-31 Available from: http://www.tandfonline.com/doi/full/10.3109/1061186X. 2014.997735.

105. Trivedi R, Kompella UB. Nanomicellar formulations for sustained drug delivery: strategies and underlying principles. Nanomedicine. 2010;5:485-505 Available from: https://www. futuremedicine.com/doi/10.2217/nnm.10.10.

106. Jhaveri AM, Torchilin VP. Multifunctional polymeric micelles for delivery of drugs and siRNA. Front Pharmacol. 2014;5 Available from: http://journal.frontiersin.org/article/10.3389/fphar.2014. 00077/abstract.

107. Kumari A, Singla R, Guliani A, Yadav SK. Nanoencapsulation for drug delivery. EXCLI J. 2014;13:265-86.

108. Ahn YS, Baik HJ, Lee BR, Lee ES, Oh KT, Lee DH, et al. Preparation of multifunctional polymeric micelles for antiviral treatment. Macromol Res. 2010;18:747-52 Available from: http://link.springer.com/10.1007/s13233-010-0802-8.

109. Nagavarma BVN, Yadav HKS, Ayaz A, Vasudha LS, Shivakumar HG. Different techniques for preparation of polymeric nanoparticles-a review. Asian J Pharm Clin Res 2012;5(3):16-23.

110. Verma G, Rajagopalan MD, Valluru R, Sridhar KA. Nanoparticles: a novel approach to target tumors. NanoMicroscale Drug Deliv Syst. Elsevier; 2017. p. 113-29. 
Available from: https://linkinghub.elsevier.com/retrieve/pii/ B9780323527279000078.

111. Singh A, Garg G, Sharma PK. Nanospheres: a novel approach for targeted drug delivery system. Int J Pharm Sci Rev Res. 2010;5: 84-8.

112. Ferrari R, Sponchioni M, Morbidelli M, Moscatelli D. Polymer nanoparticles for the intravenous delivery of anticancer drugs: the checkpoints on the road from the synthesis to clinical translation. Nanoscale. 2018;10:22701-19 Available from: http://xlink.rsc. org/?DOI=C8NR05933K.

113. Qian C, Chen Y, Feng P, Xiao X, Dong M, Yu J, et al. Conjugated polymer nanomaterials for theranostics. Acta Pharmacol Sin. 2017;38:764-81 Available from: http:/www.nature.com/articles/ aps201742.

114. Edagwa BJ, Zhou T, McMillan JM, Liu X-M, Gendelman HE. Development of HIV reservoir targeted long acting nanoformulated antiretroviral therapies. Curr Med Chem. 2014;21:4186-98 Available from: http://www.ncbi.nlm.nih.gov/ pubmed/25174930.

115. Gunaseelan S, Gunaseelan K, Deshmukh M, Zhang X, Sinko PJ. Surface modifications of nanocarriers for effective intracellular delivery of anti-HIV drugs. Adv Drug Deliv Rev. 2010;62:518 31 Available from: https://inkinghub.elsevier.com/retrieve/pii/ S0169409X09003627.

116. Ekladious I, Colson YL, Grinstaff MW. Polymer-drug conjugate therapeutics: advances, insights and prospects. Nat Rev Drug Discov. 2019;18:273-94 Available from: http://www.nature. com/articles/s41573-018-0005-0.

117. Parveen S, Arjmand F, Tabassum S. Clinical developments of antitumor polymer therapeutics. RSC Adv. 2019;9:24699-721.

118. Larson N, Ghandehari H. Polymeric conjugates for drug delivery. Chem Mater. 2012;24:840-53 Available from: https://pubs.acs. org/doi/10.1021/cm2031569.

119. Chen X, Chen X, Chen W, Ma X, Huang J, Chen R. Extended peginterferon alfa-2a (Pegasys) therapy in Chinese patients with HBeAg-negative chronic hepatitis B. J Med Virol. 2014;86:170513 Available from: http://doi.wiley.com/10.1002/jmv.24013.

120. Li J, Yu F, Chen Y, Oupický D. Polymeric drugs: advances in the development of pharmacologically active polymers. J Control Release. 2015;219:369-82 Available from: https://linkinghub. elsevier.com/retrieve/pii/S0168365915301425.

121. Kjellén L, Lindahl U. Proteoglycans: structures and interactions. Annu Rev Biochem. 1991;60:443-75 Available from: http:// www.annualreviews.org/doi/10.1146/annurev.bi.60.070191. 002303

122. Basu A, Kanda T, Beyene A, Saito K, Meyer K, Ray R. Sulfated homologues of heparin inhibit hepatitis $\mathrm{C}$ virus entry into mammalian cells. J Virol. 2007;81:3933-41 Available from: https://jvi. asm.org/content/81/8/3933.

123. Smith AAA, Kryger MBL, Wohl BM, Ruiz-Sanchis P, Zuwala K, Tolstrup M, et al. Macromolecular (pro)drugs in antiviral research. Polym Chem. 2014;5:6407-25 Available from: http://xlink.rsc. org/?DOI=C4PY00624K.

124. Andersen AHF, Riber CF, Zuwala K, Tolstrup M, Dagnæs-Hansen F, Denton PW, et al. Long-acting, potent delivery of combination antiretroviral therapy. ACS Macro Lett. 2018;7:587-91 Available from: https://pubs.acs.org/doi/10.1021/acsmacrolett.8b00179.

125. Tomalia DA. The dendritic state. Mater Today. 2005;8:34-46 Available from: https://linkinghub.elsevier.com/retrieve/pii/ S1369702105007467.

126. Tripathy S, Das MK. Dendrimers and their applications as novel drug delivery carriers. J Appl Pharm Sci. 2013;3:142-9 Available from: http://www.japsonline.com/abstract.php?article_id=1064.

127. Šebestík J, Reiniš M, Ježek J. Synthesis of dendrimers: convergent and divergent approaches. Biomed Appl Pept GlycoGlycopeptide Dendrimers, Analog Dendrimeric Struct. Vienna:
Springer Vienna; 2012. p. 55-81. Available from: http://link. springer.com/10.1007/978-3-7091-1206-9 6 .

128. Abedi-Gaballu F, Dehghan G, Ghaffari M, Yekta R, AbbaspourRavasjani S, Baradaran B, et al. PAMAM dendrimers as efficient drug and gene delivery nanosystems for cancer therapy. Appl Mater Today. 2018;12:177-90 Available from: https:// linkinghub.elsevier.com/retrieve/pii/S2352940718301641.

129. Garg T, Singh O, Arora S, Murthy RSR. Dendrimer - a novel scaffold for drug delivery. Int J Pharm Sci Rev Res. 2011;7:211-20.

130. Kensinger RD, Catalone BJ, Krebs FC, Wigdahl B, Schengrund C-L. Novel polysulfated galactose-derivatized dendrimers as binding antagonists of human immunodeficiency virus type 1 infection. Antimicrob Agents Chemother. 2004;48:1614-23 Available from: https://aac.asm.org/content/48/5/1614.

131. Kannan RM, Nance E, Kannan S, Tomalia DA. Emerging concepts in dendrimer-based nanomedicine: from design principles to clinical applications. J Intern Med. 2014;276:579-617 Available from: http://doi.wiley.com/10.1111/joim.12280.

132. Price CF, Tyssen D, Sonza S, Davie A, Evans S, Lewis GR, et al. SPL7013 gel (VivaGel®) retains potent HIV-1 and HSV-2 inhibitory activity following vaginal administration in humans. Goepfert PA, editor. PLoS One. 2011;6:e24095 Available from: https://dx.plos.org/10.1371/journal.pone.0024095.

133. Telwatte S, Moore K, Johnson A, Tyssen D, Sterjovski J, Aldunate M, et al. Virucidal activity of the dendrimer microbicide SPL7013 against HIV-1. Antiviral Res. 2011;90:195-9 Available from: https://linkinghub.elsevier.com/retrieve/pii/S0166354211002543.

134. Sepúlveda-Crespo D, Gómez R, De La Mata FJ, Jiménez JL, Muñoz-Fernández MÁ. Polyanionic carbosilane dendrimerconjugated antiviral drugs as efficient microbicides: recent trends and developments in HIV treatment/therapy. Nanomed Nanotechnol Biol Med. 2015;11:1481-98 Available from: https://linkinghub.elsevier.com/retrieve/pii/S1549963415000829.

135. Sepúlveda-Crespo D, Jiménez JL, Gómez R, De La Mata FJ, Majano PL, Muñoz-Fernández MÁ, et al. Polyanionic carbosilane dendrimers prevent hepatitis $\mathrm{C}$ virus infection in cell culture. Nanomed Nanotechnol Biol Med. 2017;13:49-58 Available from: https://linkinghub.elsevier.com/retrieve/pii/S1549963416301307.

136. Landers JJ, Cao Z, Lee I, Piehler LT, Myc PP, Myc A, et al. Prevention of influenza pneumonitis by sialic acid-conjugated dendritic polymers. J Infect Dis [Internet. 2002;186:1222-30 Available from: https://academic.oup.com/jid/article-lookup/doi/ $10.1086 / 344316$

137. García-Gallego S, Díaz L, Jiménez JL, Gómez R, de la Mata FJ, Muñoz-Fernández MÁ. HIV-1 antiviral behavior of anionic PPI metallo-dendrimers with EDA core. Eur J Med Chem. 2015;98: 139-48 Available from: https://linkinghub.elsevier.com/retrieve/ pii/S0223523415300532.

138. Lancelot A, Clavería-Gimeno R, Velázquez-Campoy A, Abian O, Serrano JL, Sierra T. Nanostructures based on ammoniumterminated amphiphilic Janus dendrimers as camptothecin carriers with antiviral activity. Eur Polym J. 2017;90:136-49 Available from: https://linkinghub.elsevier.com/retrieve/pii/ S0014305716314689.

139. Caminade A-M, Turrin C-O, Majoral J-P. Biological properties of phosphorus dendrimers. New J Chem. 2010;34:1512 Available from: http://xlink.rsc.org/?DOI=c0nj00116c.

140. Yandrapu SK, Kanujia P, Chalasani KB, Mangamoori L, Kolapalli RV, Chauhan A. Development and optimization of thiolated dendrimer as a viable mucoadhesive excipient for the controlled drug delivery: an acyclovir model formulation. Nanomed Nanotechnol Biol Med. 2013;9:514-22 Available from: https://linkinghub.elsevier.com/retrieve/pii/ S1549963412006028.

141. Martínez-Gualda B, Sun L, Rivero-Buceta E, Flores A, Quesada E, Balzarini J, et al. Structure-activity relationship studies on a Trp 
dendrimer with dual activities against HIV and enterovirus A71. Modifications on the amino acid. Antivir Res. 2017;139:32-40 Available from: https://linkinghub.elsevier.com/retrieve/pii/ S0166354216306222.

142. Mayer C. Nanocapsules as drug delivery systems. Int J Artif Organs. 2005;28:1163-71.

143. Parboosing R, Maguire GEM, Govender P, Kruger HG, Albert I, Central L, et al. Nanotechnology and the treatment of HIV infection. Viruses. 2012;4(4):488-520.

144. Singh A, Garg G, Sharma PK. Review article. Nanospheres: a novel approach for targeted drug delivery system. Int J Pharm Sci Rev Res. 2010;5:84-8.

145. Donalisio M, Leone F, Civra A, Spagnolo R, Ozer O, Lembo D, et al. Acyclovir-loaded chitosan nanospheres from nano-emulsion templating for the topical treatment of herpesviruses infections. Pharmaceutics. 2018;10:46 Available from: http://www.mdpi. com/1999-4923/10/2/46.

146. Davis ME, Brewster ME. Cyclodextrin-based pharmaceutics: past, present and future. Nat Rev Drug Discov. 2004;3:1023-35.

147. Miranda JCD, Martins TEA, Veiga F, Ferraz HG. Cyclodextrins and ternary complexes: technology to improve solubility of poorly soluble drugs. Braz J Pharm Sci. 2011;47:665-81.

148. Shelley H, Babu RJ. Role of cyclodextrins in nanoparticle based drug delivery systems. J Pharm Sci. American Pharmacists Association; 2018. https://doi.org/10.1016/j.xphs.2018.03.021.

149. Voncina B, Vivo V. Cyclodextrins in Textile Finishing. Ecofriendly text dye finish. InTech; 2013. Available from: http:// www.intechopen.com/books/eco-friendly-textile-dyeing-andfinishing/cyclodextrins-in-textile-finishing.

150. Zerkoune L, Angelova A, Lesieur S. Nano-assemblies of modified cyclodextrins and their complexes with guest molecules: incorporation in nanostructured membranes and amphiphile nanoarchitectonics design. Nanomaterials. 2014;4:741-65 Available from: http://www.mdpi.com/2079-4991/4/3/741.

151. Couvreur P, Vauthier C. Nanotechnology: intelligent design to treat complex disease. Pharm Res. 2006.

152. Vilas Boas LCP, Campos ML, Berlanda RLA, de Carvalho Neves N, Franco OL. Antiviral peptides as promising therapeutic drugs. Cell Mol Life Sci. 2019;76:3525-42 Available from: http://link. springer.com/10.1007/s00018-019-03138-w.

153. Lee W, Lee S-H, Ahn D-G, Cho H, Sung M-H, Han SH, et al. The antiviral activity of poly- $\gamma$-glutamic acid, a polypeptide secreted by Bacillus sp., through induction of CD14-dependent type I interferon responses. Biomaterials [Internet. 2013;34:9700-8 Available from: https://linkinghub.elsevier.com/retrieve/pii/ S0142961213010302.

154. Ding X, Zhang X, Chong H, Zhu Y, Wei H, Wu X, et al. Enfuvirtide (T20)-based lipopeptide is a potent HIV-1 cell fusion Inhibitor: implications for viral entry and inhibition. Kirchhoff F, editor. J Virol. 2017;91. Available from: https://jvi.asm.org/ lookup/doi/10.1128/JVI.00831-17.

155. Emileh A, Tuzer F, Yeh H, Umashankara M, Moreira DRM, LaLonde JM, et al. A model of peptide triazole entry inhibitor binding to HIV-1 gp120 and the mechanism of bridging sheet disruption. Biochemistry. 2013;52:2245-61 Available from: https://pubs.acs.org/doi/10.1021/bi400166b.

156. Alghrair ZK, Fernig DG, Ebrahimi B. Enhanced inhibition of influenza virus infection by peptide-noble-metal nanoparticle conjugates. Beilstein J Nanotechnol. 2019;10:1038-47 Available from: https://www.beilstein-journals.org/bjnano/articles/10/104.

157. Rahman G, Najaf Z, Mehmood A, Bilal S, Mian SA, Ali G. An overview of the recent progress in the synthesis and applications of carbon nanotubes. C_-J Carbon Res. 2019;5:3.

158. Kaur J, Gill GS, Jeet K. Applications of carbon nanotubes in drug delivery. Charact Biol Nanomater Drug Deliv. Elsevier; 2019. p.
113-35. Available from: https://linkinghub.elsevier.com/retrieve/ pii/B9780128140314000052.

159. Szabó A, Perri C, Csató A, Giordano G, Vuono D, Nagy JB. Synthesis methods of carbon nanotubes and related materials. Materials (Basel). 2010;3:3092-140 Available from: http://www. mdpi.com/1996-1944/3/5/3092.

160. Shao W, Arghya P, Yiyong M, Rodes L, Prakash S. Carbon nanotubes for use in medicine: potentials and limitations. Synth Appl carbon Nanotub their compos: InTech; 2013. Available from: http://www.intechopen.com/books/syntheses-and-applicationsof-carbon-nanotubes-and-their-composites/carbon-nanotubes-foruse-in-medicine-potentials-and-limitations.

161. Eatemadi A, Daraee H, Karimkhanloo H, Kouhi M, Zarghami N Carbon nanotubes: properties , synthesis , purification, and medical applications. Nanoscale Res Lett. 2014;9(1):393.

162. Kumar R, Dhanawat M, Kumar S, Singh B, Pandit J, Sinha V. Carbon nanotubes: a potential concept for drug delivery applications. Recent Pat Drug Deliv Formul. 2014;8:12-26 Available from: http://www.eurekaselect.com/openurl/content.php?genre= article \&issn $=1872-2113 \&$ volume $=8 \&$ issue $=1 \&$ spage $=12$.

163. Versiani AF, Astigarraga RG, Rocha ESO, Barboza APM, Kroon EG, Rachid MA, et al. Multi-walled carbon nanotubes functionalized with recombinant dengue virus 3 envelope proteins induce significant and specific immune responses in mice. $\mathrm{J}$ Nanobiotechnol. 2017;15:26 Available from: http:// jnanobiotechnology.biomedcentral.com/articles/10.1186/s12951017-0259-4.

164. Andrade LM, Cox L, Versiani AF, da Fonseca FG. A growing world of small things: a brief review on the nanostructured vaccines. Future Virol. 2017;12:767-79 Available from: https:// www.futuremedicine.com/doi/10.2217/fvl-2017-0086.

165. Pantarotto D, Partidos CD, Hoebeke J, Brown F, Kramer E, Briand J-P, et al. Immunization with peptide-functionalized carbon nanotubes enhances virus-specific neutralizing antibody responses. Chem Biol. 2003;10:961-6 Available from: https:// linkinghub.elsevier.com/retrieve/pii/S107455210300214X.

166. Casimir D, Alghamdi H, Ahmed YI, Garcia-Sanchez R, Misra P. Raman spectroscopy of graphene, graphite and graphene nanoplatelets. 2D Mater. IntechOpen; 2019. Available from: https://www.intechopen.com/books/2d-materials/ramanspectroscopy-of-graphene-graphite-and-graphene-nanoplatelets.

167. Aliyev E, Filiz V, Khan MM, Lee YJ, Abetz C, Abetz V. Structural characterization of graphene oxide: surface functional groups and fractionated oxidative debris. Nanomaterials. 2019;9:1180 Available from: https://www.mdpi.com/2079-4991/9/8/1180.

168. Donskyi IS, Azab W, Cuellar-Camacho JL, Guday G, Lippitz A, Unger WES, et al. Functionalized nanographene sheets with high antiviral activity through synergistic electrostatic and hydrophobic interactions. Nanoscale. 2019;11:15804-9 Available from: http:// xlink.rsc.org/?DOI=C9NR05273A.

169. Lategan K, Alghadi H, Bayati M, de Cortalezzi M, Pool E. Effects of graphene oxide nanoparticles on the immune system biomarkers produced by RAW 264.7 and human whole blood cell cultures. Nanomaterials. 2018;8:125 Available from: http://www. mdpi.com/2079-4991/8/2/125.

170. Neto AJP, Fileti EE. Elucidating the amphiphilic character of graphene oxide. Phys Chem Chem Phys. 2018;20:9507-15.

171. Dideikin AT, Vul' AY. Graphene oxide and derivatives: the place in graphene family. Front Phys. 2019;6 Available from: https:// www.frontiersin.org/article/10.3389/fphy.2018.00149/full.

172. Pokhrel R, Sompornpisut P, Chapagain P, Olson B, Gerstman B, Pandey RB. Domain rearrangement and denaturation in Ebola virus protein VP40. AIP Adv. 2018;8:125129 Available from: http://aip.scitation.org/doi/10.1063/1.5063474.

173. Deokar AR, Nagvenkar AP, Kalt I, Shani L, Yeshurun Y, Gedanken A, et al. Graphene-based "hot plate" for the capture 
and destruction of the herpes simplex virus type 1. Bioconjug Chem. 2017;28:1115-22.

174. Goodarzi S, Da Ros T, Conde J, Sefat F, Mozafari M. Fullerene: biomedical engineers get to revisit an old friend. Mater Today. 2017;20:460-80 Available from: https://linkinghub.elsevier.com/ retrieve/pii/S1369702116301808.

175. Bakry R, Vallant RM, Najam-ul-Haq M, Rainer M, Szabo Z, Huck CW, et al. Medicinal applications of fullerenes. Int J Nanomed. 2007;2:639-49 Available from: http://www.ncbi.nlm. nih.gov/pubmed/18203430.

176. Bondavalli P. Carbon and its new allotropes: fullerene, carbon nanotubes, and graphene. Graphene Relat Nanomater. Elsevier; 2018. p. 1-40. Available from: https://linkinghub.elsevier.com/ retrieve/pii/B9780323481014000011.

177. Martinez ZS, Castro E, Seong C-S, Cerón MR, Echegoyen L, Llano M. Fullerene derivatives strongly inhibit HIV-1 replication by affecting virus maturation without impairing protease activity. Antimicrob Agents Chemother. 2016;60:5731-41 Available from: https://aac.asm.org/content/60/10/5731.

178. Bosi S, Da Ros T, Spalluto G, Balzarini J, Prato M. Synthesis and anti-HIV properties of new water-soluble bisfunctionalized[60]fullerene derivatives. Bioorg Med Chem Lett. 2003;13:4437-40 Available from: https://linkinghub.elsevier. com/retrieve/pii/S0960894X03009703.

179. Mashino T, Shimotohno K, Ikegami N, Nishikawa D, Okuda K, Takahashi K, et al. Human immunodeficiency virus-reverse transcriptase inhibition and hepatitis C virus RNA-dependent RNA polymerase inhibition activities of fullerene derivatives. Bioorg Med Chem Lett. 2005;15:1107-9 Available from: https:// linkinghub.elsevier.com/retrieve/pii/S0960894X04014908.

180. Marchesan S, Da Ros T, Spalluto G, Balzarini J, Prato M. AntiHIV properties of cationic fullerene derivatives. Bioorg Med Chem Lett. 2005;15:3615-8 Available from: https://inkinghub. elsevier.com/retrieve/pii/S0960894X05006244.

181. Shoji M, Takahashi E, Hatakeyama D, Iwai Y, Morita Y, Shirayama R, et al. Anti-influenza activity of C60 fullerene derivatives. Digard P, editor. PLoS One. 2013;8:e66337 Available from: https://dx.plos.org/10.1371/journal.pone.0066337.

182. Tollas S, Bereczki I, Borbás A, Batta G, Vanderlinden E, Naesens L, et al. Synthesis of a cluster-forming sialylthio-d-galactose fullerene conjugate and evaluation of its interaction with influenza virus hemagglutinin and neuraminidase. Bioorganic Med Chem Lett. Elsevier Ltd. 2014;24:2420-3. https://doi.org/10.1016/j. bmcl.2014.04.032.

183. Iannazzo D, Pistone A, Galvagno S, Ferro S, De Luca L, Maria A, et al. Synthesis and anti-HIV activity of carboxylated and drugconjugated multi-walled carbon nanotubes. Carbon N Y. Elsevier Ltd. 2014;3977464:1-14. https://doi.org/10.1016/j.carbon.2014. 11.007.

184. Yang XX, Li CM, Li YF, Wang J, Huang CZ. Synergistic antiviral effect of curcumin functionalized graphene oxide against respiratory syncytial virus infection. Nanoscale. 2017;9:16086-92 Available from: http://xlink.rsc.org/?DOI=C7NR06520E.

185. Ye S, Shao K, Li Z, Guo N, Zuo Y, Li Q, et al. Antiviral activity of graphene oxide: how sharp edged structure and charge matter. ACS Appl Mater Interfaces. 2015;7:21571-9 Available from: http://pubs.acs.org/doi/10.1021/acsami.5b06876.

186. Iannazzo D, Pistone A, Ferro S, Luca L De, Romeo R, Buemi MR, et al. Graphene quantum dots based systems as HIV Inhibitors. Bioconjug Chem. 2018;29(9):3084-3093.

187. Illescas BM, Rojo J, Delgado R, Mart N. Multivalent glycosylated nanostructures to inhibit Ebola virus infection. J Am Chem Soc. 2017:6018-25.

188. Voronov II, Martynenko VM, Chernyak AV, Balzarini J, Schols D, Troshin PA. Synthesis and antiviral activity of water-soluble polycarboxylic derivatives of [60]fullerene loaded with 3,4 - dichlorophenyl units. Chem Biodivers. 2018;15:e1800293 Available from: http://doi.wiley.com/10.1002/cbdv.201800293.

189. Barras A, Pagneux Q, Sane F, Wang Q, Boukherroub R, Hober D, et al. High efficiency of functional carbon nanodots as entry inhibitors of herpes simplex virus type 1. ACS Appl Mater Interfaces. 2016;8:9004-13.

190. Malik P, Gulati N, Malik RK, Nagaich U. Carbon nanotubes, quantum dots and dendrimers as potential nanodevices for nanotechnology drug delivery systems. Int J Pharm Sci NanotechInt J Pharm Sci Nanotech. 2013;6:2113-24.

191. Klimov VI, Hollingsworth JA, Crooker SA, Kim H. Los Alamos National Security LLC 2007. Multifunctional nanocrystals. 2007. p. U.S. Patent 7, 261, 940.

192. Matea C, Mocan T, Tabaran F, Pop T, Mosteanu O, Puia C, et al. Quantum dots in imaging, drug delivery and sensor applications. Int J Nanomedicine. 2017;12:5421-31 Available from: https:// www.dovepress.com/quantum-dots-in-imaging-drug-deliveryand-sensor-applications-peer-reviewed-article-IJN.

193. Reshma VG, Mohanan PV. Quantum dots: applications and safety consequences. J Lumin. 2019;205:287-98 Available from: https:// linkinghub.elsevier.com/retrieve/pii/S0022231318313334.

194. Akbarzadeh A, Rezaei-Sadabady R, Davaran S, Joo SW, Zarghami N, Hanifehpour Y, et al. Liposome: classification, preparation, and applications. Nanoscale Res Lett. 2013;8:102 Available from: http://nanoscalereslett.springeropen.com/ articles/10.1186/1556-276X-8-102.

195. Yong K, Wang Y, Roy I, Rui H, Swihart MT, Law W, et al. Preparation of quantum dot / drug nanoparticle formulations for traceable targeted delivery and therapy. Theranostics. 2012;2(7): 681.

196. Yadavalli T, Shukla D. Role of metal and metal oxide nanoparticles as diagnostic and therapeutic tools for highly prevalent viral infections. Nanomed Nanotechnol Biol Med. 2017;13:219-30 Available from: https://linkinghub.elsevier.com/retrieve/pii/ S1549963416301289.

197. Demchenko HO, Rusinchuk NM. Evaluation of the efficiency of interparticle interactions in nanosystems. J Nanotechnol. 2019;2019:1-8 Available from: https://www.hindawi.com/ journals/jnt/2019/4270454/.

198. Markman JL, Rekechenetskiy A, Holler E, Ljubimova JY. Nanomedicine therapeutic approaches to overcome cancer drug resistance. Adv Drug Deliv Rev. 2013;65:1866-79. https://doi. org/10.1016/j.addr.2013.09.019.

199. Guo J, Rahme K, He Y, Li L-L, Holmes J, O’Driscoll C. Gold nanoparticles enlighten the future of cancer theranostics. Int $\mathrm{J}$ Nanomedicine. 2017;12:6131-52 Available from: https://www. dovepress.com/gold-nanoparticles-enlighten-the-future-ofcancer-theranostics-peer-reviewed-article-IJN.

200. Huang X, El-Sayed MA. Gold nanoparticles: optical properties and implementations in cancer diagnosis and photothermal therapy. J Adv Res. 2010;1:13-28 Available from: https://linkinghub. elsevier.com/retrieve/pii/S2090123210000056.

201. Bayo J, MP D, Martinez E. Medicinal chemistry. Future Med Chem. 2015;7:450-61.

202. Paul AM, Shi Y, Acharya D, Douglas JR, Cooley A, Anderson JF, et al. Delivery of antiviral small interfering RNA with gold nanoparticles inhibits dengue virus infection in vitro. J Gen Virol. 2014;95:1712-22 Available from: http://jgv.microbiologyresearch. org/content/journal/jgv/10.1099/vir.0.066084-0.

203. Cagno V, Andreozzi P, D'Alicarnasso M, Silva PJ, Mueller M, Galloux M, et al. Broad-spectrum non-toxic antiviral nanoparticles with a virucidal inhibition mechanism. Nat Mater. 2018;17:195203.

204. Halder A, Das S, Ojha D, Chattopadhyay D, Mukherjee A. Highly monodispersed gold nanoparticles synthesis and inhibition of herpes simplex virus infections. Mater Sci Eng C Mater Biol Appl. 
2018;89:413-21 Available from: http://www.ncbi.nlm.nih.gov/ pubmed/29752114.

205. Rudramurthy G, Swamy M, Sinniah U, Ghasemzadeh A. Nanoparticles: alternatives against drug-resistant pathogenic microbes. Molecules. 2016;21:836 Available from: http://www. mdpi.com/1420-3049/21/7/836.

206. Reidy B, Haase A, Luch A, Dawson K, Lynch I. Mechanisms of silver nanoparticle release, transformation and toxicity: a critical review of current knowledge and recommendations for future studies and applications. Materials (Basel). 2013;6:2295-350 Available from: http://www.mdpi.com/1996-1944/6/6/2295.

207. Prabhu S, Poulose EK. Silver nanoparticles: mechanism of antimicrobial action, synthesis, medical applications, and toxicity effects. Int Nano Lett. 2012;2:32 Available from: http://link. springer.com/10.1186/2228-5326-2-32.

208. Galdiero S, Falanga A, Vitiello M, Cantisani M, Marra V, Galdiero M. Silver nanoparticles as potential antiviral agents. Molecules. 2011;16:8894-918 Available from: http://www. mdpi.com/1420-3049/16/10/8894.

209. Baram-Pinto D, Shukla S, Perkas N, Gedanken A, Sarid R. Inhibition of herpes simplex virus type 1 infection by silver nanoparticles capped with mercaptoethane sulfonate. Bioconjug Chem. 2009;20:1497-502 Available from: https://pubs.acs.org/ doi/10.1021/bc $900215 b$.

210. Xiang D, Chen Q, Pang L, Zheng C. Inhibitory effects of silver nanoparticles on H1N1 influenza A virus in vitro. J Virol Methods. 2011;178:137-42 Available from: https://linkinghub. elsevier.com/retrieve/pii/S0166093411003788.

211. Li Y, Lin Z, Zhao M, Xu T, Wang C, Hua L, et al. Silver nanoparticle based codelivery of oseltamivir to inhibit the activity of the H1N1 influenza virus through ROS-mediated signaling pathways. ACS Appl Mater Interfaces. 2016;8:24385-93 Available from: https://pubs.acs.org/doi/10.1021/acsami.6b06613.

212. Wang M, Marepally SK, Vemula PK, Xu C. Inorganic nanoparticles for transdermal drug delivery and topical application. Nanosci Dermatol. Elsevier; 2016. p. 57-72. Available from: https:// linkinghub.elsevier.com/retrieve/pii/B9780128029268000057.

213. Zaid K. Alghrair DGF and Ebrahimi B. Enhanced inhibition of influenza virus infection by peptide-noble metal nanoparticle conjugates. BioRXiv. 2018;15:2017-9. Available from: https://www. uam.es/gruposinv/meva/publicacionesjesus/capitulos_espanyol jesus/2005_motivacionparaelaprendizajePerspectivaalumnos.pdf, https://www.researchgate.net/profile/Juan_Aparicio7/publication/ 253571379 Los estudios sobre el cambio conceptual.

214. Szunerits S, Barras A, Khanal M, Pagneux Q, Boukherroub R. Nanostructures for the inhibition of viral infections. Molecules. 2015;20:14051-81 Available from: http://www.mdpi.com/1420$3049 / 20 / 8 / 14051$

215. Antoine TE, Hadigal SR, Yakoub AM, Mishra YK, Bhattacharya $\mathrm{P}$, Haddad C, et al. Intravaginal zinc oxide tetrapod nanoparticles as novel immunoprotective agents against genital herpes. J Immunol. 2016;196:4566-75 Available from: http://www. jimmunol.org/lookup/doi/10.4049/jimmunol.1502373.

216. AshaRani PV, Low Kah Mun G, Hande MP, Valiyaveettil S. Cytotoxicity and genotoxicity of silver nanoparticles in human cells. ACS Nano. 2009;3:279-90 Available from: http://pubs. acs.org/doi/10.1021/nn800596w.

217. Kawata K, Osawa M, Okabe S. In vitro toxicity of silver nanoparticles at noncytotoxic doses to HepG2 human hepatoma cells. Environ Sci Technol. 2009;43:6046-51 Available from: http:// pubs.acs.org/doi/abs/10.1021/es900754q.

218. Lin Z, Li Y, Guo M, Xiao M, Wang C, Zhao M, et al. Inhibition of H1N1 influenza virus by selenium nanoparticles loaded with zanamivir through p38 and JNK signaling pathways. RSC Adv. Royal Society of Chemistry; 2017;7:35290-6. Available from: http://xlink.rsc.org/?DOI=C7RA06477B.
219. Li Y, Lin Z, Guo M, Zhao M, Xia Y, Wang C, et al. Inhibition of H1N1 influenza virus-induced apoptosis by functionalized selenium nanoparticles with amantadine through ROS-mediated AKT signaling pathways. Int J Nanomedicine. 2018;13:2005-16.

220. Hang X, Peng H, Song H, Qi Z, Miao X, Xu W. Antiviral activity of cuprous oxide nanoparticles against hepatitis $\mathrm{C}$ virus in vitro. $\mathrm{J}$ Virol Methods. 2015;222:150-7 Available from: https:// linkinghub.elsevier.com/retrieve/pii/S0166093415002268.

221. Vijayakumar S, Ganesan S. Gold nanoparticles as an HIV entry inhibitor. Curr HIV Res. 2012;10:643-6 Available from: http:/ www.eurekaselect.com/openurl/content.php?genre=article\&issn= $1570-162 X \&$ volume $=10 \&$ issue $=8 \&$ spage $=643$.

222. Tiwari P, Vig K, Dennis V, Singh S. Functionalized gold nanoparticles and their biomedical applications. Nanomaterials. 2011;1:3163 Available from: http://www.mdpi.com/2079-4991/1/1/31.

223. Borker S, Patole M, Moghe A, Pokharkar V. Engineering of pectin-reduced gold nanoparticles for targeted delivery of an antiviral drug to macrophages: in vitro and in vivo assessment. Gold Bull. 2017;50:235-46 Available from: http://link.springer.com/ 10.1007/s13404-017-0213-0.

224. Kesarkar R, Yeole M, Dalvi B, Sharon M, Chowdhary A. Gold nanosphere intermediate for drug conjugation. Int J Pharm Sci Rev. 2015;31:143-6.

225. Ga'al H, Fouad H, Tian J, Hu Y, Abbas G, Mo J. Synthesis, characterization and efficacy of silver nanoparticles against Aedes albopictus larvae and pupae. Pestic Biochem Physiol. 2018;144:49-56 Available from: https://linkinghub.elsevier.com/ retrieve/pii/S0048357517301232.

226. Mori Y, Ono T, Miyahira Y, Nguyen VQ, Matsui T, Ishihara M. Antiviral activity of silver nanoparticle/chitosan composites against H1N1 influenza A virus. Nanoscale Res Lett. 2013;8:93 Available from: http://nanoscalereslett.springeropen.com/articles/ 10.1186/1556-276X-8-93.

227. Mukherjee A, Waters AK, Kalyan P, Achrol AS, Kesari S, Yenugonda VM. Lipid-polymer hybrid nanoparticles as a nextgeneration drug delivery platform: state of the art, emerging technologies, and perspectives. Int J Nanomed. 2019;14:1937-52 Available from: https://www.dovepress.com/lipid-polymerhybrid-nanoparticles-as-a-next-generation-drug-delivery $\% 2 \mathrm{D} \%$ 2Dpeer-reviewed-article-IJN.

228. Dave V, Tak K, Sohgaura A, Gupta A, Sadhu V, Reddy KR. Lipid-polymer hybrid nanoparticles: synthesis strategies and biomedical applications. J Microbiol Methods. 2019;160:130-42 Available from: https://linkinghub.elsevier.com/retrieve/pii/ S0167701219300533.

229. Date T, Nimbalkar V, Kamat J, Mittal A, Mahato RI, Chitkara D. Lipid-polymer hybrid nanocarriers for delivering cancer therapeutics Tushar. J Control Release. Elsevier B.V; 2017; Available from: https://doi.org/10.1016/j.jconrel.2017.12.016.

230. Article R, Kumari L, Al HA, Sakure K, Badwaik HR. Recent advancements in the lipid polymer hybrid nanoparticles for drug delivery: an overview. Acta Sci Pharm Sci. 2019;3:21-8.

231. Joshy KS, Snigdha S, Thomas A, George A, Kalarikkal N, Pothen LA, et al. Nanotechnology in HIV / AIDS: lipids and lipid hybrid systems-novel delivery approaches on antiviral drugs. JSM Nanotechnol Nanomed. 2018;6.

232. Joshy KS, Snigdha S, Kalarikkal N, Pothen LA, Thomas S. Gelatin modified lipid nanoparticles for anti retroviral drug delivery. Chem. Phys. Lipids. Elsevier Ireland Ltd; 2017. https://doi. org/10.1016/j.chemphyslip.2017.07.002.

233. Joshy KS, George A, Jose J, Kalarikkal N, Pothen LA, Thomas S. Novel dendritic structure of alginate hybrid nanoparticles for effective anti-viral drug delivery. Int J Biol Macromol. Elsevier B.V. 2017;103:1265-75. https://doi.org/10.1016/j.ijbiomac.2017.05.094.

234. Joshy KS, George A, Snigdha S, Joseph B, Kalarikkal N, Pothen LA, et al. Novel core-shell dextran hybrid nanosystem for anti- 
viral drug delivery. Mater Sci Eng C. Elsevier B.V; 2018;\#pagerange\#. Available from: https://linkinghub.elsevier. com/retrieve/pii/S0928493117336962.

235. Joshy KS, Snigdha S, Anne G, Nandakumar K, Laly AP, Sabu T. Poly (vinyl pyrrolidone)-lipid based hybrid nanoparticles for anti viral drug delivery. Chem Phys Lipids. 2018;210:82-9.

236. Jin K, Luo Z, Zhang B, Pang Z. Biomimetic nanoparticles for inflammation targeting. Acta Pharm Sin B. 2018;8:23-33 Available from: https://linkinghub.elsevier.com/retrieve/pii/ S2211383517303672.

237. Vijayan V, Mohapatra A, Uthaman S, Park IK. Recent advances in nanovaccines using biomimetic immunomodulatory materials. Pharmaceutics. 2019;11:534 Available from: https://www.mdpi. com/1999-4923/11/10/534.

238. Schwarz B, Uchida M, Douglas T. Biomedical and catalytic opportunities of virus-like particles in nanotechnology. Adv Virus Res. 2017;97:1-60 Available from: https://linkinghub.elsevier. com/retrieve/pii/S0065352716300501.

239. Abdoli A, Soleimanjahi H, Kheiri MT, Jamali A, Sohani H, Abdoli M, et al. Reconstruction of H3N2 influenza virus based virosome in-vitro. Iran J Microbiol. 2013;5:166-71 Available from: http://www.ncbi.nlm.nih.gov/pubmed/23825736.

240. Parodi A, Molinaro R, Sushnitha M, Evangelopoulos M, Martinez $\mathrm{JO}$, Arrighetti N, et al. Bio-inspired engineering of cell- and viruslike nanoparticles for drug delivery. Biomaterials. Elsevier Ltd. 2017;147:155-68. https://doi.org/10.1016/j.biomaterials.2017.09. 020 .

241. Yang G, Chen S, Zhang J. Bioinspired and biomimetic nanotherapies for the treatment of infectious diseases. Front Pharmacol. 2019;10 Available from: https://www.frontiersin. org/article/10.3389/fphar.2019.00751/full.

242. Kanekiyo M, Wei C-J, Yassine HM, McTamney PM, Boyington JC, Whittle JRR, et al. Self-assembling influenza nanoparticle vaccines elicit broadly neutralizing H1N1 antibodies. Nature. 2013;499:102-6 Available from: http://www.nature.com/articles/ nature12202.

243. Marcandalli J, Fiala B, Ols S, Perotti M, de van der Schueren W, Snijder J, et al. Induction of potent neutralizing antibody responses by a designed protein nanoparticle vaccine for respiratory syncytial virus. Cell. 2019;176:1420-1431.e17 Available from: https:// linkinghub.elsevier.com/retrieve/pii/S0092867419301096.

244. Karimi M, Ghasemi A, Sahandi Zangabad P, Rahighi R, Moosavi Basri SM, Mirshekari H, et al. Smart micro/nanoparticles in stimulus-responsive drug/gene delivery systems. Chem Soc Rev. 2016;45:1457-501 Available from: http://xlink.rsc.org/?DOI= C5CS00798D.

245. Clawson C, Ton L, Aryal S, Fu V, Esener S, Zhang L. Synthesis and characterization of lipid-polymer hybrid nanoparticles with pH-triggered poly(ethylene glycol) shedding. Langmuir. 2011;27:10556-61 Available from: https://pubs.acs.org/doi/10. 1021/la202123e

246. Du J, Lane LA, Nie S. Stimuli-responsive nanoparticles for targeting the tumor microenvironment. J Control Release. 2015;219:205-14 Available from: https://linkinghub.elsevier. com/retrieve/pii/S0168365915300936.

247. Hallan SS, Kaur P, Kaur V, Mishra N, Vaidya B. Lipid polymer hybrid as emerging tool in nanocarriers for oral drug delivery. Artif Cells Nanomed Biotechnol. 2014:1-16.

248. Mahlumba P, Choonara Y, Kumar P, du Toit L, Pillay V. Stimuliresponsive polymeric systems for controlled protein and peptide delivery: future implications for ocular delivery. Molecules. 2016;21:1002 Available from: http://www.mdpi.com/1420-3049/ 21/8/1002.

249. Li N, Yu M, Deng L, Yang J, Dong A. Thermosensitive hydrogel of hydrophobically-modified methylcellulose for intravaginal drug delivery. J Mater Sci Mater Med. 2012;23:1913-9 Available from: http://ink.springer.com/10.1007/s10856-012-4664-9.

250. Shao P, Wang B, Wang Y, Li J, Zhang Y. The application of thermosensitive nanocarriers in controlled drug delivery. $\mathrm{J}$ Nanomater. 2011;2011:1-12 Available from: http://www. hindawi.com/journals/jnm/2011/389640/.

251. Tian W, Han S, Huang X, Han M, Cao J, Liang Y, et al. LDH hybrid thermosensitive hydrogel for intravaginal delivery of antiHIV drugs. Artif Cells Nanomed Biotechnol. 2019;47:1234-40 Available from: https://www.tandfonline.com/doi/full/10.1080/ 21691401.2019.1596935.

252. Dalpiaz A, Pavan B. Nose-to-brain delivery of antiviral drugs: a way to overcome their active efflux? Pharmaceutics. 2018;10:39 Available from: http://www.mdpi.com/1999-4923/10/2/39.

253. de Dios AS, Díaz-García ME. Multifunctional nanoparticles: analytical prospects. Anal Chim Acta. 2010;666:1-22 Available from: https://linkinghub.elsevier.com/retrieve/pii/ S0003267010003211.

254. Sanvicens N, Marco MP. Multifunctional nanoparticles - properties and prospects for their use in human medicine. Trends Biotechnol. 2008;26:425-33.

255. Alkubaisi NA, Aref NMA. Dispersed gold nanoparticles potentially ruin gold barley yellow dwarf virus and eliminate virus infectivity hazards. Appl Nanosci. 2017;7:31-40 Available from: http://link.springer.com/10.1007/s13204-016-0540-0.

256. Liu D, Lian Y, Fang Q, Liu L, Zhang J, Li J. Hyaluronic-acidmodified lipid-polymer hybrid nanoparticles as an efficient ocular delivery platform for moxifloxacin hydrochloride. Int J Biol Macromol. 2018;116:1026-36 Available from: https:// linkinghub.elsevier.com/retrieve/pii/S0141813018306032.

257. Lee M-Y, Yang J-A, Jung HS, Beack S, Choi JE, Hur W, et al. Hyaluronic acid-gold nanoparticle/interferon $\alpha$ complex for targeted treatment of hepatitis $\mathrm{C}$ virus infection. ACS Nano. 2012;6:9522-31 Available from: https://pubs.acs.org/doi/10. 1021/nn302538y.

258. Liu Y, Tan J, Thomas A, Ou-Yang D, Muzykantov VR. The shape of things to come: importance of design in nanotechnology for drug delivery. Ther Deliv. 2012;3:181-94 Available from: http:// www.ncbi.nlm.nih.gov/pubmed/22834196.

259. Auría-Soro C, Nesma T, Juanes-Velasco P, Landeira-Viñuela A, Fidalgo-Gomez $\mathrm{H}$, Acebes-Fernandez $\mathrm{V}$, et al. Interactions of nanoparticles and biosystems: microenvironment of nanoparticles and biomolecules in nanomedicine. Nanomaterials. 2019;9:1365 Available from: https://www.mdpi.com/2079-4991/9/10/1365.

260. Samuelsson LB, Bovbjerg DH, Roecklein KA, Hall MH. Sleep and circadian disruption and incident breast cancer risk: an evidence-based and theoretical review. Neurosci Biobehav Rev. 2018;84:35-48. https://doi.org/10.1016/j.neubiorev.2017.10.011.

261. Lombardo D, Kiselev MA, Caccamo MT. Smart nanoparticles for drug delivery application: development of versatile nanocarrier platforms in biotechnology and nanomedicine. J Nanomater. 2019;2019:1-26 Available from: https://www.hindawi.com/ journals/jnm/2019/3702518/.

262. Mendel, J., 1999. Dispersions and coatings. Nanostructure Sci Technol. 1999;35-47 Springer, Dordrecht.

263. Law W, Reynolds JL, Yong K. Anti-HIV-1 nanotherapeutics: promises and challenges for the future. Int $\mathrm{J}$ Nanomedicine. 2012;7:5301-14.

264. Xiao K, Li Y, Luo J, Lee JS, Xiao W, Gonik AM, et al. The effect of surface charge on in vivo biodistribution of PEG-oligocholic acid based micellar nanoparticles. Biomaterials. 2011;32:3435-46 Available from: https://linkinghub.elsevier.com/retrieve/pii/ S0142961211000342.

265. Sharma A, Madhunapantula SV, Robertson GP. Toxicological considerations when creating nanoparticle-based drugs and drug delivery systems. Expert Opin Drug Metab Toxicol. 2012;8:47- 
69 Available from: http://www.tandfonline.com/doi/full/10.1517/ 17425255.2012.637916.

266. Kaur CD, Nahar M, Jain NK. Lymphatic targeting of zidovudine using surface-engineered liposomes. J Drug Target. 2008;16:798 805 .

267. Al-Halifa S, Gauthier L, Arpin D, Bourgault S, Archambault D. Nanoparticle-based vaccines against respiratory viruses. Front Immunol. 2019;10 Available from: https://www.frontiersin.org/ article/10.3389/fimmu.2019.00022/full.

268. Ther JCS, Agarwal M. Role of nanovaccine in immunotherapy. J Cell Sci Ther. 2015;s8:8-11 Available from: https://www. omicsonline.org/open-access/role-of-nanovaccine-inimmunotherapy-2157-7013-S8-003.php?aid=61096.

269. Chu SY, Vostiar I, Karki S, Moore GL, Lazar GA, Pong E, et al. Inhibition of B cell receptor-mediated activation of primary human B cells by coengagement of CD19 and FcgammaRIlb with Fc-engineered antibodies. Mol Immunol. 2008;45:3926-33 Available from: http://www.ncbi.nlm.nih.gov/pubmed/18691763.

270. Wang C, Zhu W, Luo Y, Wang B-Z. Gold nanoparticles conjugating recombinant influenza hemagglutinin trimers and flagellin enhanced mucosal cellular immunity. Nanomed Nanotechnol Biol Med. 2018;14:1349-60 Available from: https://linkinghub. elsevier.com/retrieve/pii/S1549963418300698.

271. Marques Neto LM, Kipnis A, Junqueira-Kipnis AP. Role of metallic nanoparticles in vaccinology: implications for infectious disease vaccine development. Front Immunol. 2017;8 Available from: http://journal.frontiersin.org/article/10.3389/fimmu.2017. 00239/full.

272. Deng L, Mohan T, Chang TZ, Gonzalez GX, Wang Y, Kwon Y$\mathrm{M}$, et al. Double-layered protein nanoparticles induce broad protection against divergent influenza A viruses. Nat Commun. 2018;9:359 Available from: http://www.nature.com/articles/ s41467-017-02725-4.

273. Liu Q, Zheng X, Zhang C, Shao X, Zhang X, Zhang Q, et al. Conjugating influenza a (H1N1) antigen to ntrimethylaminoethylmethacrylate chitosan nanoparticles improves the immunogenicity of the antigen after nasal administration. J Med Virol. 2015;87:1807-15 Available from: http://doi.wiley. com/10.1002/jmv.24253

274. Dabaghian M, Latifi AM, Tebianian M, NajmiNejad H, Ebrahimi SM. Nasal vaccination with r4M2e.HSP70c antigen encapsulated into N-trimethyl chitosan (TMC) nanoparticulate systems: preparation and immunogenicity in a mouse model. Vaccine. 2018;36: 2886-95 Available from: https://linkinghub.elsevier.com/retrieve/ pii/S0264410X18302597.

275. Francica JR, Lynn GM, Laga R, Joyce MG, Ruckwardt TJ, Morabito KM, et al. Thermoresponsive polymer nanoparticles co-deliver RSV F trimers with a TLR-7/8 adjuvant. Bioconjug Chem. 2016;27:2372-2385. Available from: https://pubs.acs. org/doi/10.1021/acs.bioconjchem.6b00370.

276. Ulery BD, Phanse Y, Sinha A, Wannemuehler MJ, Narasimhan B, Bellaire BH. Polymer chemistry influences monocytic uptake of polyanhydride nanospheres. Pharm Res. 2009;26:683-90 Available from: http://link.springer.com/10.1007/s11095-0089760-7.

277. Hervé P-L, Deloizy C, Descamps D, Rameix-Welti M-A, Fix J, McLellan JS, et al. RSV N-nanorings fused to palivizumabtargeted neutralizing epitope as a nanoparticle RSV vaccine. Nanomed Nanotechnol Biol Med. 2017;13:411-20 Available from: https://linkinghub.elsevier.com/retrieve/pii/ S1549963416301149.

278. Zhang S, Huang S, Lu L, Song X, Li P, Wang F. Curdlan sulfateO-linked quaternized chitosan nanoparticles: potential adjuvants to improve the immunogenicity of exogenous antigens via intranasal vaccination. Int J Nanomedicine. 2018;13:2377-94 Available from: https://www.dovepress.com/curdlan-sulfate-o-
linked-quaternized-chitosan-nanoparticles-potential\%2D\% 2Dpeer-reviewed-article-IJN.

279. Ulery BD, Petersen LK, Phanse Y, Kong CS, Broderick SR, Kumar D, et al. Rational design of pathogen-mimicking amphiphilic materials as nanoadjuvants. Sci Rep. 2011;1:198 Available from: http://www.nature.com/articles/srep00198.

280. Bohlmann GM. Process economic considerations for production of ethanol from biomass feedstocks. Ind Biotechnol. 2006;2:14 20 Available from: http://www.liebertpub.com/doi/10.1089/ind. 2006.2.14.

281. López-Sagaseta J, Malito E, Rappuoli R, Bottomley MJ. Selfassembling protein nanoparticles in the design of vaccines. Comput Struct Biotechnol J. 2016;14:58-68 Available from: https://inkinghub.elsevier.com/retrieve/pii/S200103701530009X.

282. Vicente S, Diaz-Freitas B, Peleteiro M, Sanchez A, Pascual DW, Gonzalez-Fernandez A, et al. A polymer/oil based nanovaccine as a single-dose immunization approach. Boyaka PN, editor. PLoS One. 2013;8:e62500 Available from: https://dx.plos.org/10.1371/ journal.pone.0062500.

283. Dacoba TG, Omange RW, Li H, Crecente-Campo J, Luo M, Alonso MJ. Polysaccharide nanoparticles can efficiently modulate the immune response against an HIV peptide antigen. ACS Nano. 2019;13:4947-59 Available from: https://pubs.acs.org/doi/10. 1021/acsnano.8b07662.

284. Yi Y, Lagniton PNP, Ye S, Li E, Xu R-H. COVID-19: what has been learned and to be learned about the novel coronavirus disease. Int J Biol Sci. 2020;16:1753-66 Available from: http://www. ijbs.com/v16p1753.htm.

285. Pal M, Berhanu G, Desalegn C, Kandi V. Severe acute respiratory syndrome coronavirus-2 (SARS-CoV-2): an update. Cureus. 2020;12 Available from: https://www.cureus.com/articles/29589severe-acute-respiratory-syndrome-coronavirus-2-sars-cov-2-anupdate.

286. Su D, Lou Z, Sun F, Zhai Y, Yang H, Zhang R, et al. Dodecamer structure of severe acute respiratory syndrome coronavirus nonstructural protein nsp10. J Virol. 2006;80:7902-8 Available from: https://jvi.asm.org/content/80/16/7902.

287. Fang SG, Shen H, Wang J, Tay FPL, Liu DX. Proteolytic processing of polyproteins $1 \mathrm{a}$ and $1 \mathrm{ab}$ between non-structural proteins 10 and $11 / 12$ of coronavirus infectious bronchitis virus is dispensable for viral replication in cultured cells. Virology. 2008;379:175-80 Available from: https://linkinghub.elsevier.com/retrieve/pii/ S0042682208004340.

288. Hofmann H, Pöhlmann S. Cellular entry of the SARS coronavirus. Trends Microbiol. 2004;12:466-72 Available from: https:// linkinghub.elsevier.com/retrieve/pii/S0966842X04001878.

289. Fehr AR, Perlman S. Coronaviruses: an overview of their replication and pathogenesis. Coronaviruses. 2015;1282:1-23 Available from: http://link.springer.com/10.1007/978-1-4939-2438-7 1.

290. Boopathi S, Poma AB, Kolandaivel P. Novel 2019 coronavirus structure, mechanism of action, antiviral drug promises and rule out against its treatment. J Biomol Struct Dyn. 2020:1-10 Available from: https://www.tandfonline.com/doi/full/10.1080/ 07391102.2020 .1758788 .

291. Lai C-C, Shih T-P, Ko W-C, Tang H-J, Hsueh P-R. Severe acute respiratory syndrome coronavirus 2 (SARS-CoV-2) and coronavirus disease-2019 (COVID-19): the epidemic and the challenges. Int J Antimicrob Agents. 2020;55:105924 Available from: https:// linkinghub.elsevier.com/retrieve/pii/S0924857920300674.

292. An Overview of Nanotechnology Patents Focusing on Coronaviruses | STATNANO. [cited 2020 Jun 5]. Available from: https://statnano.com/news/67513/An-Overview-ofNanotechnology-Patents-Focusing-on-Coronaviruses.

293. Dormont F, Brusini R, Cailleau C, Reynaud F, Peramo A, Gendron A, et al. Squalene-based multidrug nanoparticles for improved mitigation of uncontrolled inflammation. Sci Adv. 2020: 
eaaz5466 Available from: https://advances.sciencemag.org/ lookup/doi/10.1126/sciadv.aaz5466.

294. Arcturus reports positive preclinical data for its COVID-19 vaccine candidate $\mid$ Arcturus Therapeutics, Inc.. [cited 2020 Jun 5]. Available from: https://ir.arcturusrx.com/news-releases/newsrelease-details/arcturus-reports-positive-preclinical-data-its-covid19-vaccine.

295. Alnylam ${ }^{\circledR}$ Pharmaceuticals. [cited 2020 Jun 5]. Available from: https://www.alnylam.com/.

296. Sohrab SS, El-Kafrawy SA, Mirza Z, Kamal MA, Azhar EI. Design and delivery of therapeutic siRNAs: application to MERS-coronavirus. Curr Pharm Des. 2018;24:62-77 Available from: http://www.eurekaselect.com/156958/article.

297. University of Waterloo developing DNA-based COVID-19 vaccine | Waterloo Stories | University of Waterloo. [cited 2020 Jun 5]. Available from: https://uwaterloo.ca/stories/news/ university-waterloo-developing-dna-based-covid-19-vaccine.

298. China leverages nanotechnology to deactivate the novel coronavirus | STATNANO. [cited 2020 Jun 5]. Available from: https:// statnano.com/news/67544/China-Leverages-Nanotechnology-toDeactivate-the-Novel-Coronavirus.

299. Novavax awarded funding from CEPI for COVID-19 vaccine development | Novavax Inc. - IR Site. [cited 2020 Jun 5]. Available from: https://ir.novavax.com/news-releases/news-release-details/ novavax-awarded-funding-cepi-covid-19-vaccine-development.

300. Forest business working to prevent spread of coronavirus, products sent internationally | WSET. [cited 2020 Jun 5]. Available from: https://wset.com/news/local/forest-business-working-toprevent-spread-of-coronavirus-products-sent-internationally.

301. Iran leverages nanotechnology to launch West Asia's largest face mask production plant STATNANO. [cited 2020 Jun 5]. Available from: https://statnano.com/news/67581/IranLeverages-Nanotechnology-to-Launch-West-Asia's-LargestFace-Mask-Production-Plant.

302. COVID-19 report \& analysis - World Nano Foundation. [cited 2020 Jun 5]. Available from: https://www.worldnanofoundation. com/covid-19-report-analysis.

303. Producing iron oxide nanoparticles for 150,000 COVID-19 tests per week. [cited 2020 Jun 6]. Available from: https://www. nanowerk.com/nanotechnology-news2/newsid=54893.php.

304. Nanotechnology in battle against coronavirus | STATNANO. [cited 2020 Jun 2]. Available from: https://statnano.com/ nanotechnology-in-battle-against-coronavirus.

305. Patra JK, Das G, Fraceto LF, Campos EVR, Rodriguez-Torres M d P, Acosta-Torres LS, et al. Nano based drug delivery systems: recent developments and future prospects. J Nanobiotechnol. 2018;16:71 Available from: https://jnanobiotechnology. biomedcentral.com/articles/10.1186/s12951-018-0392-8.

306. Ventola CL. Progress in nanomedicine: approved and investigational nanodrugs. P T. 2017;42:742-55. Available from: http:// www.ncbi.nlm.nih.gov/pubmed/29234213.

307. Sukhanova A, Bozrova S, Sokolov P, Berestovoy M, Karaulov A, Nabiev I. Dependence of nanoparticle toxicity on their physical and chemical properties. Nanoscale Res Lett. 2018;13:44 Available from: https://nanoscalereslett.springeropen.com/ articles/10.1186/s11671-018-2457-x.

308. Fu PP, Xia Q, Hwang H-M, Ray PC, Yu H. Mechanisms of nanotoxicity: generation of reactive oxygen species. J Food Drug Anal. 2014;22:64-75 Available from: https://linkinghub. elsevier.com/retrieve/pii/S1021949814000064.

309. Ahadian S, Radisic M. Nanotoxicity. Nanobiomaterials Sci Dev Eval. Elsevier; 2017. p. 233-48. Available from: https:// linkinghub.elsevier.com/retrieve/pii/B9780081009635000124.

310. Sereemaspun A, Rojanathanes R, Wiwanitkit V. Effect of gold nanoparticle on renal cell: an implication for exposure risk. Ren Fail. 2008;30:323-5.
311. Antony JJ, Sivalingam PCB. Toxicological effects of silver nanoparticles. Environ Toxicol Pharmacol. 2015;40:729-32.

312. Yoisungnern T, Choi Y-J, Han JW, Kang M-H, Das JGS Internalization of silver nanoparticles into mouse spermatozoa results in poor fertilization and compromised embryo development. Sci Rep. 2015;5:11170.

313. Gaillet S. RJ-MF 2015. Silver nanoparticles: their potential toxic effects after oral exposure and underlying mechanisms-a review. Chem Toxicol. 2015;77:58-63.

314. Karlsson HL, Cronholm P, Gustafsson JML. Copper oxide nanoparticles are highly toxic: a comparison between metal oxide nanoparticles and carbon nanotubes. Chem Res Toxicol. 2008;21:1726-32.

315. Jin CY, Zhu BS, Wang XF, et al. Cytotoxicity of titanium dioxide nanoparticles in mouse fibroblast cells. Chem Res Toxicol. 2008;21:1871e7.

316. Wang C-C, Wang S, Xia Q, et al. Phototoxicity of zinc oxide nanoparticles in $\mathrm{HaCaT}$ keratinocytes e generation of oxidative DNA damage during UVA and visible light irradiation. J Nanosci Nanotechnol. 2013;13:3880e8.

317. Murphy FA, Poland CA, Duffin R, Al-Jamal KT, Ali-Boucetta H, Nunes A, et al. Length-dependent retention of carbon nanotubes in the pleural space of mice initiates sustained inflammation and progressive fibrosis on the parietal pleura. Am J Pathol. 2011;178:2587-600 Available from: https://linkinghub.elsevier. com/retrieve/pii/S0002944011002744.

318. Gutiérrez-Praena D, Pichardo S, Sánchez E, Grilo A, Cameán AM, Jos A. Influence of carboxylic acid functionalization on the cytotoxic effects induced by single wall carbon nanotubes on human endothelial cells (HUVEC). Toxicol in Vitro. 2011;25:18838 Available from: https://linkinghub.elsevier.com/retrieve/pii/ S0887233311001639.

319. Li R, Wang X, Ji Z, Sun B, Zhang H, Chang CH, et al. Surface charge and cellular processing of covalently functionalized multiwall carbon nanotubes determine pulmonary toxicity. ACS Nano. 2013;7:2352-68 Available from: https://pubs.acs.org/doi/10. $1021 / \mathrm{nn} 305567 \mathrm{~s}$.

320. Seabra AB, Paula AJ, de Lima R, Alves OL, Durán N. Nanotoxicity of graphene and graphene oxide. Chem Res Toxicol. 2014;27:159-68 Available from: https://pubs.acs.org/ doi/10.1021/tx400385x.

321. Voigt N, Henrich-Noack P, Kockentiedt S, Hintz W, Tomas J, Sabel BA. Toxicity of polymeric nanoparticles in vivo and in vitro. J Nanopart Res. 2014;16:2379 Available from: http:// link.springer.com/10.1007/s11051-014-2379-1.

322. Mourdikoudis S, Pallares RM, Thanh NTK. Characterization techniques for nanoparticles: comparison and complementarity upon studying nanoparticle properties. Nanoscale. 2018;10:12871-934 Available from: $h t t p: / / x l i n k . r s c . o r g / ? D O I=C 8 N R 02278 J$.

323. Soares S, Sousa J, Pais A, Vitorino C. Nanomedicine: principles, properties, and regulatory issues. Front Chem. 2018;6 Available from: https://www.frontiersin.org/article/10.3389/fchem.2018. 00360/full

324. Shafagati N, Patanarut A, Luchini A, Lundberg L, Bailey C, Petricoin E, et al. The use of nanotrap particles for biodefense and emerging infectious disease diagnostics. Pathog Dis. 2014;71:164-76 Available from: https://academic.oup.com/ femspd/article-lookup/doi/10.1111/2049-632X.12136.

325. Jaworski E, Saifuddin M, Sampey G, Shafagati N, Van Duyne R, Iordanskiy S, et al. The use of nanotrap particles technology in capturing HIV-1 virions and viral proteins from infected cells. Jacobson S, editor. PLoS One. 2014;9:e96778 Available from: http://dx.plos.org/10.1371/journal.pone.0096778.

326. Shafagati N, Lundberg L, Baer A, Patanarut A, Fite K, Lepene B, et al. The use of nanotrap particles in the enhanced detection of Rift Valley fever virus nucleoprotein. Ikegami T, editor. PLoS 
One. 2015;10:e128215 Available from: https://dx.plos.org/10. 1371/journal.pone.0128215.

327. Shafagati N, Narayanan A, Baer A, Fite K, Pinkham C, Bailey C, et al. The use of nanotrap particles as a sample enrichment method to enhance the detection of Rift Valley fever virus. Peters CJ, editor. PLoS Negl Trop Dis. 2013;7:e2296 Available from: https://dx.plos.org/10.1371/journal.pntd.0002296.

328. Shafagati N, Fite K, Patanarut A, Baer A, Pinkham C, An S, et al. Enhanced detection of respiratory pathogens with nanotrap particles. Virulence. 2016;7:756-69.

329. Cheng H, Chen J, Cai Z, Du L, Hou J, Qiao X, et al. Development of GEM-PA-nanotrap for purification of foot-and-mouth disease virus. Vaccine. 2019;37:3205-13 Available from: https:// linkinghub.elsevier.com/retrieve/pii/S0264410X19305663.

330. Akhrymuk I, Lin S-C, Sun M, Patnaik A, Lehman C, Altamura L, et al. Magnetic nanotrap particles preserve the stability of Venezuelan equine encephalitis virus in blood for laboratory detection. Front Vet Sci. 2020;6 Available from: https://www. frontiersin.org/article/10.3389/fvets.2019.00509/full.

331. Lin S-C, Carey BD, Callahan V, Lee J-H, Bracci N, Patnaik A, et al. Use of nanotrap particles for the capture and enrichment of Zika, chikungunya and dengue viruses in urine. Roques $\mathrm{P}$, editor. PLoS One. 2020;15:e0227058 Available from: https://dx.plos. org/10.1371/journal.pone.0227058.

332. Mavroidis C, Ferreira A, editors. Nanorobotics: current approaches and techniques: Springer; 2013.

333. Manjunath A, Kishore V. The promising future in medicine: nanorobots. Biomed Sci Eng. 2014;2:42-7.

334. Nistor MT, Rusu AG. Nanorobots with applications in medicine. Polym Nanomater Nanotherapeutics. Elsevier; 2019. p. 123-49. Available from: https://linkinghub.elsevier.com/retrieve/pii/ B9780128139325000030

335. Ravi Bandakkanavar. Anti-HIV using nanorobots - Krazytech. [cited 2018 Aug 11]. Available from: https://krazytech.com/ technical-papers/anti-hiv-using-nano-robots.

336. Cavalli R, Soster M, Argenziano M. Nanobubbles: a promising efficienft tool for therapeutic delivery. Ther Deliv. 2016;7:117-38 Available from: http://www.future-science.com/doi/10.4155/tde. 15.92.

337. Song L, Wang G, Hou X, Kala S, Qiu Z, Wong KF, et al. Biogenic nanobubbles for effective oxygen delivery and enhanced photodynamic therapy of cancer. Acta Biomater. 2020;108:313-25 Available from: https://linkinghub.elsevier.com/retrieve/pii/ S1742706120301756.

338. Prabhakar A, Banerjee R. Nanobubble liposome complexes for diagnostic imaging and ultrasound-triggered drug delivery in cancers: a theranostic approach. ACS Omega. 2019;4:15567-80 Available from: https://pubs.acs.org/doi/10.1021/acsomega.9b01924.

339. Thakkar S, Misra M. Electrospun polymeric nanofibers: new horizons in drug delivery. Eur J Pharm Sci. 2017;107:148-67 Available from: https://linkinghub.elsevier.com/retrieve/pii/ S0928098717304001.

340. Yarin AL, Pourdeyhimi B, Ramakrishna S. Fundamentals and applications of micro and nanofibers. Cambridge: Cambridge
University Press; 2014. Available from: http://ebooks.cambridge. org/ref/id/CBO9781107446830.

341. Carson D, Jiang Y, Woodrow KA. Tunable release of multiclass anti-HIV drugs that are water-soluble and loaded at high drug content in polyester blended electrospun fibers. Pharm Res. 2016;33:125-36 Available from: http://link.springer.com/10. 1007/s11095-015-1769-0.

342. Novel nanofiber-based technology could help prevent HIV/AIDS transmission. [cited 2014 Nov 4]. Available from: https:/www. sciencedaily.com/releases/2014/11/141104183713.htm.

343. Wu Y, Weil T. Nanodiamonds for biological applications. Phys Sci Rev. 2017;2. Available from: http://www.degruyter.com/ view/j/psr.2017.2.issue-6/psr-2016-0104/psr-2016-0104.xml.

344. Moore LK, Gatica M, Chow EK, Ho D. Diamond-based nanomedicine: enhanced drug delivery and imaging. Disruptive Sci Technol. 2012;1:54-61 Available from: http://online. liebertpub.com/doi/abs/10.1089/dst.2012.0007.

345. Roy U, Drozd V, Durygin A, Rodriguez J, Barber P, Atluri V, et al. Characterization of nanodiamond-based anti-HIV drug delivery to the brain. Sci Rep. 2018;8:1603 Available from: http:// www.nature.com/articles/s41598-017-16703-9.

346. Ivanova VT, Ivanova MV, Spitsyn BV, Garina KO, Trushakova $\mathrm{SV}$, Manykin AA, et al. Interaction of nanodiamonds materials with influenza viruses. J Phys Conf Ser. 2012;345:012019 Available from: http://stacks.iop.org/1742-6596/345/i=1/a= 012019?key=crossref.d83b2b535cc4ca7bf683a33aa6646d80.

347. Pham NB, Ho TT, Nguyen GT, Le TT, Le NT, Chang H-C, et al. Nanodiamond enhances immune responses in mice against recombinant HA/H7N9 protein. J Nanobiotechnol. 2017;15:69 Available from: http://jnanobiotechnology.biomedcentral.com/ articles/10.1186/s12951-017-0305-2.

348. Zitzmann C, Kaderali L. Mathematical analysis of viral replication dynamics and antiviral treatment strategies: from basic models to age-based multi-scale modeling. Front Microbiol. 2018;9 Available from: https://www.frontiersin.org/article/10.3389/ fmicb.2018.01546/full.

349. Niewiadomska AM, Jayabalasingham B, Seidman JC, Willem L, Grenfell B, Spiro D, et al. Population-level mathematical modeling of antimicrobial resistance: a systematic review. BMC Med. 2019;17:81 Available from: https://bmcmedicine.biomedcentral. com/articles/10.1186/s12916-019-1314-9.

350. Jiang S, Wang K, Li C, Hong G, Zhang X, Shan M, et al. Mathematical models for devising the optimal Ebola virus disease eradication. J Transl Med. 2017;15:124 Available from: http:// translational-medicine.biomedcentral.com/articles/10.1186/ s12967-017-1224-6.

351. Chen T-M, Rui J, Wang Q-P, Zhao Z-Y, Cui J-A, Yin L. A mathematical model for simulating the phase-based transmissibility of a novel coronavirus. Infect Dis Poverty. 2020;9:24 Available from: https://idpjournal.biomedcentral.com/articles/10. 1186/s40249-020-00640-3

Publisher's note Springer Nature remains neutral with regard to jurisdictional claims in published maps and institutional affiliations. 